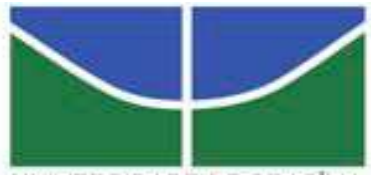

UNIVERSIDADE DE BRASÍLIA

Centro de Excelência em Turismo

Pós-graduação Lato Sensu

Curso de Especialização em Gestão de Negócios em Turismo

\title{
PLANO DE NEGÓCIO: O CASO DA SUPERA PRODUÇÕES.
}

Kellen Cruz Felizari 
UNIVERSIDADE DE BRASÍLIA

Centro de Excelência em Turismo

Pós-graduação Lato Sensu

Curso de Especialização em Gestão de Negócios em Turismo

\title{
PLANO DE NEGÓCIO: O CASO DA SUPERA PRODUÇÕES.
}

\author{
Kellen Cruz Felizari \\ Msc. Gilson Zehetmeyer Borda \\ Orientador \\ Monografia apresentada ao Centro de \\ Excelência em turismo - CET, da \\ Universidade de Brasília - UnB, como \\ requisito parcial à obtenção do grau de \\ Especialista em Gestão de Negócios em \\ Turismo.
}


Felizari, Kellen Cruz.

Plano de negócio: o caso da Supera Produções / Kellen Cruz Felizari xi; 113 fls: il.

Trabalho de Conclusão do Curso de Pós-graduação lato sensu em Gestão de Negócios em Turismo

Brasília - DF, junho de 2007.

Orientador: Gilson Zehetmeyer Borda, MSc

1. Empresa de eventos 2. Plano estratégico 3. Plano de marketing 4. Plano operacional 5. plano financeiro 6. Título 
UNIVERSIDADE DE BRASÍLIA

Centro de Excelência em Turismo

Pós-graduação Lato Sensu

Curso de Especialização em Gestão de Negócios em Turismo

Monografia apresentada ao Centro de Excelência em turismo - CET, da Universidade de Brasília - UnB, como requisito parcial à obtenção do grau de Especialista em Gestão de Negócios em Turismo.

Kellen Cruz Felizari

Aprovado por:

Professor Gilson Zehetmeyer Borda, MSc

Professor (a) Walter Eustáquio Ribeiro, MSc

Professor (a) Joana Bicalho, MSc

Brasília, junho de 2007 


\section{DEDICATÓRIA}

Ao meu alicerce, meu porto seguro, meu amado pai, que me ensinou a levantar a cada tombo, que me ensinou o que é certo e o que é errado, que me faz criar coragem para lutar.

À memória de minha mãe querida, que me ensinou amizade, amor, caridade e acima de tudo me ensinou a ser uma pessoa melhor. 


\section{AGRADECIMENTOS}

A Deus, pela minha existência;

À minha mãe Célia, minha estrela guia;

Ao meu pai Egídio, pelas palavras sábias de força e carinho nas horas mais difíceis, obrigada por tudo;

À minha irmã Ellen e cunhado Luis Rodrigo, pela dedicação, paciência e amizade;

Aos meus irmãos Alan e Alex pela ajuda e atenção ;

Ao meu amado noivo Giovanny, pelo equilíbrio nos momentos de aflição, pelas dicas e boas idéias oferecidas e pelo grande amor que sentimos;

À minha amiga Sheila, pelas conversas e esclarecimentos, amiga valeu;

Aos meus grandes amigos Rodrigo, Thadeu, Wal e Marina, simplesmente pela nossa amizade;

Ao Kinho, grande amigo, pelas válidas informações;

A Kleber e Júnior, estimados amigos, que me auxiliaram no desenvolvimento desse trabalho;

Aos meus incontáveis amigos, que por questões de espaço não estiveram aqui presentes, mas que estão no meu coração;

Ao Sr. Marco Aurélio, que me fez compreender ainda mais o mundo dos eventos;

A Carlos e Marlei pelos esclarecimentos contábeis;

Às empresas visitadas que me receberam de forma amistosa me ajudando a concluir esse trabalho;

Ao meu orientador Gilson Borda, que fez com que essa pesquisa se tornasse possível.

A todas as pessoas que de alguma forma ajudaram para a finalização dessa pesquisa. 


\section{RESUMO}

O presente estudo objetiva a realização de um plano de negócio para verificar a viabilidade de um empreendimento de organização de eventos sociais na cidade de Dourados, MS. Optou-se pela criação do plano de negócio por ser um instrumento de planejamento que projeta a realidade e perspectiva da empresa, definindo as estratégias. O resultado das análises foi a criação da empresa Supera Produções, empreendimento que pretende se destacar no mercado regional de eventos a partir de uma abordagem diferenciada e criativa do conteúdo dos seus produtos. Para isso foi desenvolvido o plano estratégico, que cria a identidade da empresa, os passos a serem seguidos, seus valores, sua visão, sua missão, bem como, seus produtos e serviços terceirizados. O Plano de Marketing, que analisa o ambiente, o mercado, os concorrentes, identifica os consumidores definindo o produto, preço, praça e promoção. O Plano Operacional define a estrutura organizacional para os dois primeiros anos, a estrutura física da empresa, e cargos e responsabilidades. Por fim, - Plano Financeiro que analisa a viabilidade econômica do empreendimento, identificando os investimentos, desembolsos operacionais, projeção de vendas, capital de giro, faturamento além de outros indicadores orçamentários. Contudo o estudo conclui a viabilidade do empreendimento proposto nesse trabalho, demonstrando as chances e os riscos do sucesso do negócio, uma vez que todos os passos aqui delineados sejam seguidos cuidadosamente.

Palavras-chave: 1. empresa de eventos, 2. plano estratégico, 3. plano de marketing, 4. plano operacional, 5. plano financeiro. 


\begin{abstract}
The present work aims to accomplish a business plan to verify the viability of an events organization enterprise in the city of Dourados, MS. The business plan creation was opted as it is a planning tool that projects the reality and the perspective of the enterprise, defining the strategies. The results of the analysis was the creation of the company Supera Produções, an enterprise that intends to point up itself in the regional events market, from a different and creative approach of the content of its products. As to be accomplish, the strategic plan was developed, so an identity of the company is created, as long with footsteps to be followed, its values, vision, aim and also its products and services to be provided by others. The Marketing Plan, that analyses the environment, the market, concurrents, identifies the costumers defining the product, price, market and promotion. The Operational Plan defines the organizational structure for the first two years, the company's physical structure, jobs and responsabilities. At last, the Financial Plan that analyses the economical viability of the enterprise, identifying investments, operational spends, sales projection, net working capital, income, besides other financial indicatives. However, the study concludes for the viability of the proposed enterprise in this work, demonstrating the chances and risks concerning the business, if all steps established here are carefully followed.
\end{abstract}

Key-words: 1 . events enterprise, 2. strategic plan, 3. marketing plan, 4. operational plan, 5. financial plan. 


\section{LISTA DE ILUSTRAÇÕES ORGANOGRAMAS}

llustração 1 - Logomarca da empresa $\quad 64$

llustração 2 - Layout da empresa $\quad 72$

Ilustração 3 - Hierarquia da empresa relativa ao ano 1

Ilustração 4 - Hierarquia da empresa relativa ao ano $2 \quad 74$ 


\section{LISTA DE QUADROS E TABELAS}

Quadro 1 Roteiro de sessão solene de colação de grau 30

Quadro $2 \quad$ Nomenclatura das bodas $\quad 31$

Quadro $3 \quad$ Tipos de planejamento 33

Quadro $4 \quad$ Perguntas necessárias para o plano estratégico 40

Quadro $5 \quad$ Sumario Start up $\quad 49$

Quadro $6 \quad$ Locais para eventos, seguidos de suas características e valores 53

Quadro $7 \quad$ Cardápio do serviço terceirizado de buffet 53

Quadro 8 Decoração para cerimônia de boda e/ou casamento 54

Quadro 9 Decoração para festa de debutante $\quad 55$

Quadro 10 Decoração do baile de formatura $\quad 55$

Quadro 11 Serviços de DJ 56

Quadro $12 \quad$ Análise do concorrente 1 60

Quadro 13 Análise do concorrente 2 60

Quadro 14 Análise do concorrente 3 60

Quadro 15 Matriz SWOT $\quad 62$

$\begin{array}{lll}\text { Quadro } 16 & \text { Estrutura física da empresa } & 71\end{array}$

Quadro $17 \quad$ Cargos e funções dos funcionários para o ano $1 \quad 75$

Quadro $18 \quad$ Cargos e funções dos funcionários para o ano 2

Quadro 19 Projeção de vendas $\quad 81$

Tabela $1 \quad$ Pacote de formatura 66

$\begin{array}{lll}\text { Tabela } 2 & \text { Pacote de casamento/boda } & 68\end{array}$

Tabela $3 \quad$ Pacote de festa de debutante 69

$\begin{array}{lll}\text { Tabela } 4 & \text { Investimento inicial } & 78\end{array}$

Tabela $5 \quad$ Remunerações e encargos para o ano $1 \quad 79$

Tabela $6 \quad$ Remunerações e encargos para o ano $2 \quad 80$

Tabela $7 \quad$ Despesas mensais para o ano $1 \quad 80$

Tabela $8 \quad$ Despesas mensais para o ano $2 \quad 81$

Tabela 9 Custos fixos e variáveis 83 
1. INTRODUÇÃO 01

1.1 DELIMITAÇÃO DO TEMA 02

1.2 PROBLEMA 02

1.3 HIPÓTESE 02

1.4 OBJETIVOS 03

1.4.1 Objetivo geral 03

1.4.2 Objetivos específicos 03

1.5 JUSTIFICATIVA 03

1.5.1 Oportunidades 03

1.5.2 Importância e viabilidade $\quad 04$

1.6 RESUMO DA METODOLOGIA 04

2. METODOLOGIA 06

2.1 TIPO DE PESQUISA QUANTO AOS OBJETIVOS 06

2.2 PROCEDIMENTO DE COLETA DE DADOS 07

2.3 FONTES DE INFORMAÇÃO 10

2.4 MÉTODOS DE ABORDAGEM 11

2.5 MÉTODOS DE PROCEDIMENTOS 12

2.6 TÉCNICAS DE PESQUISA 14

2.7 UNIVERSO DE PESQUISA $\quad 15$

2.7.1 Técnicas de amostragem: $\quad 15$

3 REFERENCIAL TEÓRICO 18

3.1 TURISMO 18

3.1.1 Planejamento do turismo 19

3.1.2 Turismo de eventos 21

3.1.2.1 Os Eventos $\quad 22$

3.1.2.2 Eventos e cadeia produtiva do turismo $\quad 27$

3.1.2.3 Formatura e casamento (cerimonial, protocolo e etiqueta) 29

3.2 PLANEJAMENTO ESTRATÉGICO 32

3.2.1 Planejamento estratégico em organizações turísticas 32

3.2.2 Planejamento estratégico em empresas de eventos 34

3.2.2.1 O Profissional de Eventos - gestor $\quad 35$

3.2.3 Empreendedorismo 36 
3.2.4 Ética empresarial

4. PLANO DE NEGÓCIO 39

4.1 PLANO ESTRATÉGICO 39

4.1.1 Sumario Executivo 40

4.1.2 Objetivo do Plano 41

4.1.3 Descrição do Negócio 41

4.1.4 Visão 41

4.1.5 Missão 42

4.1.6 Objetivos e metas 43

4.1.6.1 Objetivos 43

4.1.6.2 Metas 43

4.1.7 Fatores críticos de sucesso 44

4.1.8 Princípios e valores $\quad 44$

4.2 RESUMO DA EMPRESA $\quad 45$

4.2.1 A empresa 46

4.2.2 Descrição da forma jurídica 47

4.2.3 Currículos dos proprietários 48

4.2.4 Sumário startup $\quad 48$

4.2.5 Localização da empresa $\quad 49$

4.3 PRODUTOS E SERVIÇOS 50

4.3.1 Descrição dos produtos e serviços 50

4.3.2 Serviços terceirizados 52

4.4 PLANO DE MARKETING 57

4.4.1 Análise de mercado $\quad 58$

4.4.2 Segmentação do mercado 58

4.4.3 Análise da concorrência $\quad 59$

4.4.4 Análise SWOT $\quad 61$

4.4.5 Marketing Mix 62

4.4.5.1 Produto (posicionamento) 62

4.4.5.2 Preço 64

4.4.5.3 Praça 69

$\begin{array}{ll}\text { 4.4.5.4 Promoção } & 70\end{array}$

4.5 PLANO OPERACIONAL 71

$\begin{array}{ll}\text { 4.5.1 Estrutura física } & 71\end{array}$

$\begin{array}{ll}\text { 4.5.2 Disposição interna } & 72\end{array}$ 
4.5.6 Cargos e responsabilidades $\quad 75$

4.6 PLANO FINANCEIRO 77

4.6.1 Investimento Inicial 77

4.6.2 Desembolsos operacionais $\quad 79$

4.6.2.1 Remuneração e encargos 79

4.6.3 Faturamento 81

4.6.4 Fluxo de caixa 82

4.6.5 Indicadores 82

4.6.5.1Taxa Interna de Retorno (TIR) 82

4.6.5.2 Ponto de Equilíbrio 83

4.6.5.3 Período de Payback (Tempo de Retorno) 85

5 CONSIDERAÇÕES FINAIS 86

Referências bibliográficas 88

Apêndice $\quad 94$

Apêndice A - Planilha de Fluxo de Caixa - ano 1

Apêndice B - Planilha de Fluxo de Caixa - ano $2 \quad 97$

$\begin{array}{ll}\text { Anexos } & 99\end{array}$

Anexo 1 - Orçamento DJ 100

Anexo 2 - Orçamento Decoração 104

Anexo 3 - Orçamento Clube Indaiá $\quad 111$ 


\section{INTRODUÇÃO}

A cidade de Dourados, localizada no estado do Mato Grosso do Sul (MS), possui cerca de 180 mil habitantes, e sua economia é baseada em agricultura e pecuária. Possui 4 instituições privadas de ensino superior, além das Universidades Federal (UFGD) e Estadual (UEMS). São aproximadamente 95 cursos formando turmas semestral e anualmente. Observa-se, também, a intenção do governo estadual e municipal de transformá-la em "cidade universitária".

Aproveitando essa oportunidade, percebe-se a importância de uma empresa organizadora de eventos especializada em formaturas. Mas, como este tipo de evento é sazonal, a empresa também prestará outros serviços, como boda, casamento e festa de debutante, sendo que, para isso, faz-se necessária a criação de um plano de negócio, um planejamento inicial que guiará o desenvolvimento da empresa. Destaca-se, aqui, a necessidade do desenvolvimento de assuntos relacionados ao turismo, uma vez que parentes e amigos se deslocam para o local do evento com intuito de prestigiar o anfitrião, hospedando-se hotéis, e usufruindo dos serviços de restaurantes e comércio, movimentando, assim, a cadeia produtiva do turismo.

Considera-se que a realização de um bom plano de negócio seja o primeiro passo para a identificação da empresa, onde se define as direções a serem seguidas em seu processo de implantação.

Para melhor compreensão, SALIM et. al. (2005, p. 3) define plano de negócios como "Um documento que contém a caracterização do negócio, sua forma de operar, suas estratégias, seu plano para conquistar uma fatia de mercado e as projeções de despesas, receitas e resultados financeiros."

A Supera Produções objetiva proporcionar momentos de grande alegria e plenitude à seus clientes, os quais esperam que sua comemoração de aniversário, casamento e formatura, seja um momento diferente, inesquecível e cheio de emoções. 
Assim, surge o problema de pesquisa: É viável a implantação de uma empresa de organização de eventos de formatura, boda, casamento e festa de debutante na cidade de Dourados, MS?

\subsection{DELIMITAÇÃO DO TEMA}

Observando a oportunidade de mercado, e a intenção de fazer de um sonho um acontecimento, percebe-se a necessidade de um planejamento empresarial para estudar a viabilidade do empreendimento de eventos. Por isso o tema está assim delimitado: Plano de Negócio: O caso da Supera Produções.

\subsection{PROBLEMA}

Levando-se em consideração a existência de cerca de 95 cursos na cidade que formam turmas semestral e anualmente, e tendo em vista a existência de 5 empresas de eventos, das quais 3 são especializadas em formatura e cerimonial, surge, então, o problema de pesquisa: É viável a implantação de uma empresa de organização de eventos de formatura, boda, casamento e festa de debutante na cidade de Dourados, MS?

\subsection{HIPÓTESES}

- Hipótese positiva: É viável a implantação de uma empresa de organização de eventos, especializada em formaturas, na cidade de Dourados. 
- Hipótese negativa: Não está clara a viabilidade de uma empresa de organização de eventos especializada em formaturas na cidade de Dourados.

\subsection{OBJETIVOS}

\subsubsection{Objetivo geral}

Analisar a viabilidade de implantação de uma empresa de organização de eventos de boda, casamento, festa de debutante e formatura, na cidade de Dourados.

\subsubsection{Objetivos específicos}

- Conhecer o sistema de planejamento da área de eventos;

- Realizar análise de campo para o desenvolvimento do plano de negócio.

\subsection{JUSTIFICATIVA}

\subsubsection{Oportunidade}

Após perceber-se a oportunidade oferecida pelo contexto particular da cidade, planejou-se, a partir de novembro de 2006, a criação de uma empresa de 
organização de eventos em Dourados, pois, tendo em vista a quantidade de cursos que formam alunos, e levando em consideração o pequeno número de empresas do ramo de eventos na região, percebe-se uma carência desse tipo de serviço, o que faz com que algumas turmas de formandos busquem empresas de fora da cidade acontecendo o mesmo com outros tipos de eventos sociais como boda, casamento e festa de debutante.

\subsubsection{Importância e viabilidade}

É perceptível a importância do planejamento em qualquer área profissional: no mundo dos negócios não é diferente. É preciso definir objetivos e traçar estratégias de forma planejada e monitorada para a obtenção do sucesso. Dessa forma, o Plano de Negócio é um roteiro que precisa ser seguido e monitorado a cada passo, tornando-se fundamental para a implantação de uma empresa.

\subsection{RESUMO DA METODOLOGIA}

Metodologia é a seqüência básica de métodos que devem ser usados no desenvolvimento de um trabalho científico. De acordo com Gil (2002, p. 162), metodologia é a etapa do trabalho onde "descrevem-se os procedimentos a serem seguidos na realização da pesquisa em termos claros e precisos. Recomenda-se, portanto, que em sua redação sejam utilizados verbos de ação, como identificar, verificar, descrever e analisar".

As informações levantadas para a realização dessa monografia foram baseadas em pesquisa bibliográfica, pesquisa documental, estudo de caso e pesquisa de campo. Foram utilizados os métodos de abordagem dedutiva e de procedimento monográfico, bem como a técnica de observação assistemática por história de vida.

Para isso, o presente trabalho está dividido da seguinte forma: 
Capítulo 1 - Introdução - nesse capítulo encontra-se uma explanação do trabalho, definindo o tema, objetivos, problema e hipóteses.

Capítulo 2 - Referencial Teórico - é evidenciado aqui os passos para a construção do plano de negócio.

Capítulo 3 - Metodologia - nessa etapa do trabalho é informado o tipo de pesquisa realizada e os principais métodos e procedimentos usados.

Capítulo 4 - Plano de Negócio - nesse capítulo é feita a análise, a interpretação dos dados e o desenvolvimento do plano de negócio.

Capítulo 5 - Considerações Finais - de acordo com a análise dos dados, confirmar-se-á uma das hipóteses: a viabilidade ou não da implementação da empresa Supera Produções em Dourados. 


\section{METODOLOGIA}

Em seu sentido mais geral, o método é a ordem que se deve impor aos diferentes processos necessários para atingir um fim dado ou um resultado desejado. Nas ciências, entende-se por método o conjunto de processos que o espírito humano deve empregar na investigação e demonstração da verdade. Cervo e Bervian apud Marconi e Lakatos (2000, p. 45).

O conceito de Método para Marconi e Lakatos (2000, p. 46) é:

O método é o conjunto das atividades sistemáticas e racionais que, com maior segurança e economia, permite alcançar o objetivo conhecimentos válidos e verdadeiros -, traçando o caminho a ser seguido, detectando erros e auxiliando as decisões do cientista.

Sobre o trabalho científico e seu fim, Marconi e Lakatos (2000, p. 46) também observa: "A finalidade da atividade científica é a obtenção da verdade, por intermédio da comprovação de hipóteses, que, por sua vez, são pontes entre a observação da realidade e a teoria científica, que explica a realidade".

Considerando os conceitos anteriores, o presente trabalho seguiu o seguinte critério metodológico:

\subsection{TIPO DE PESQUISA QUANTO AOS OBJETIVOS}

Quanto aos objetivos, segundo DENCKER (2004), a pesquisa pode ser:

a) Exploratória:

Procura aprimorar idéias ou descobrir intuições. Caracteriza-se por possuir um planejamento flexível envolvendo em geral levantamento bibliográfico, entrevistas com pessoas experientes e análise de exemplos similares. DENCKER (2004, p. 124). 
b) Descritiva: "Procura descrever fenômenos ou estabelecer relações entre variáveis. Utiliza técnicas padronizadas de coleta de dados como o questionário e a observação sistemática”. DENCKER (2004, p. 124).

c) Explicativa:

Procura identificar os fatores que determinam ou contribuem para a concorrência dos fenômenos. Caracteriza-se pela utilização do método experimental (nas ciências físicas) e observacional (nas ciências sociais). DENCKER (2004, p. 125).

Essa pesquisa foi descritiva, pois descreve uma realidade prática, comparando-a com um modelo teórico.

\subsection{PROCEDIMENTO DE COLETA DE DADOS}

Quanto ao procedimento de coleta, a pesquisa pode ser:

a) Pesquisa bibliográfica:

Desenvolvida a partir de material já elaborado: livros e artigos científicos. Embora existam pesquisas apenas bibliográficas, toda pesquisa requer uma fase preliminar de levantamento e revisão de literatura existente para elaboração conceitual e definição dos marcos teóricos. DENCKER (2004, p. 125).

b) Pesquisa documental:

Difere da pesquisa bibliográfica por utilizar material que ainda não recebeu tratamento analítico ou que pode ser reelaborado. As fontes documentais podem ser documentos de primeira mão conservados em arquivos de instituições públicas e privadas (formulários da Embratur, registro de hóspedes) ou pessoais (diários, relatos de viagem). Além desses temos documentos de segunda mão: relatórios (de pesquisa, de empresas) e dados estatísticos (IBGE). DENCKER (2004, p. 125). 
c) Pesquisa experimental: "Consiste em verificar as alterações causadas por uma determinada variável no objeto escolhido para estudo". DENCKER (2004, p. 126).

Segundo GIL (2002, p. 46), "o experimento representa o melhor exemplo de pesquisa científica", afirmando ainda que:

Essencialmente, a pesquisa experimental consiste em determinar um objeto de estudo, selecionar as variáveis que seriam capazes de influência-lo, definir as formas de controle e de observação dos efeitos que a variável produz no objeto. (GIL, 2002, p. 46)

d) Pesquisa ex-post-facto:

Também chamada de pesquisa quase experimental, pois se baseia nos princípios da pesquisa experimental, com a diferença que o pesquisador não tem controle sobre as variáveis. Comparam-se dois grupos basicamente semelhantes atribuindo-se as diferenças existentes entre eles a um fator identificado em apenas um deles. Esse fator, que ocorre espontaneamente, corresponde ao 'estímulo' utilizado na pesquisa experimental. DENCKER (2004, p. 126).

e) Levantamento:

Consiste na coleta de dados referentes a uma dada população a partir de uma amostra selecionada dentro de critérios estatísticos. As conclusões obtidas com a amostra são projetadas para o universo. [...] O levantamento não é indicado para análise de problemas complexos, que exigem uma profundidade maior. É como uma fotografia, oferecendo uma visão estática do momento pesquisado. Os dados são mais descritivos que explicativos. DENCKER (2004, p. 127).

f) Estudo de caso:

É o estudo profundo e exaustivo de determinados objetos ou situações. [...] O estudo de caso pode envolver exame de registros, observação de ocorrência de fatos, entrevistas estruturadas e nãoestruturadas ou qualquer outra técnica de pesquisa. $\mathrm{O}$ objeto de estudo de caso, por sua vez, pode ser um indivíduo, um grupo, uma organização, um conjunto de organizações ou até mesmo uma situação. DENCKER (2004, p. 127). 
g) Pesquisa ação:

Pesquisa empírica com estreita vinculação com uma ação ou resolução de um problema coletivo. [...] Promove a intervenção direta e contínua na realidade. É útil para a solução de problemas comunitários e pode ser utilizada na realização de estágio no contexto das organizações. DENCKER (2004, p. 127).

Para Gil (2002, p. 146):

A pesquisa-ação concretiza-se com o planejamento de uma ação destinada a enfrentar o problema que foi objeto de investigação. Isso implica a elaboração de um plano ou projeto que indique:

a) quais os objetivos que se pretende atingir;

b) a população a ser beneficiada;

c) a natureza da relação da população com as instituições que serão afetadas;

d) a identificação das medidas que podem contribuir para melhorar a situação;

e) os procedimentos a serem adotados para assegurar a participação da população e incorporar suas sugestões: e

f) a determinação das formas de controle do processo e de avaliação de seus resultados.

h) Pesquisa participante:

Pesquisa realizada mediante a integração do pesquisador, que assume uma função no grupo a ser pesquisado, mas sem obedecer a uma proposta predeterminada de ação. O objetivo é obter conhecimento mais profundo do grupo. O grupo pesquisado tem conhecimento da finalidade dos objetivos da pesquisa e da identidade do pesquisador. Essa metodologia permite a observação das ações no próprio momento em que ocorrem. Oferece uma visão dinâmica dos processos de interação e de relação entre grupos. Especialmente indicada para estudos de grupos e comunidades. . DENCKER (2004, p. 128).

Os procedimentos de coleta de dados adotados no desenvolvimento desse trabalho foram a pesquisa bibliográfica, já que foi utilizado livros e artigos relacionados a área em estudo, a pesquisa documental, uma vez que houve a análise de documentos e registros públicos, bem como estudo de caso, pois buscouse estudar a cidade de Dourados e a necessidade de mais uma empresa de eventos sociais. 


\title{
2.3 FONTES DE INFORMAÇÃO
}

Sobre pesquisa experimental e suas fontes de informação, PADUA (2000, p. 58) observa:

\begin{abstract}
Pesquisa experimental busca relações entre fatos sociais ou fenômenos físicos através da identificação e manipulação das variáveis que determinam a relação causa-efeito (estímulo-resposta) proposta na hipótese de trabalho. A verificabilidade, bem como a quantificação dos resultados, são elementos essenciais a este tipo de pesquisa. Os termos pesquisa de laboratório e pesquisa de campo servem para designar o local onde elas se desenvolvem, a partir de sua característica básica que é o controle de variáveis com base no referencial teórico de cada área do conhecimento.
\end{abstract}

a) Laboratório: a pesquisa "exige instrumental específico e ambiente adequado para se analisar/ comprovar hipóteses pela experimentação e pelo controle das variáveis." PADUA (2000, p. 58)

b) Campo: a pesquisa "tem as mesmas exigências no âmbito da ciência, não envolvendo a experimentação propriamente dita." PADUA (2000, p. 59).

Sobre a determinação do ambiente, GIL (2002, p. 98) ressalta que:

[...] as pesquisas experimentais podem ter como ambiente 0 laboratório ou o campo. Quando é realizada em laboratório, a possibilidade de controle das variáveis é bem maior, já que o ambiente pode ser preparado de forma que permita a maximização do efeito das variáveis independentes sobre a dependente. Nos experimentos de campo, o controle das variáveis é bastante reduzido, tanto por constituir empreendimento custoso quanto por poder artificializar situações que se desejam naturais.

c) Bibliográfica: A pesquisa bibliográfica é desenvolvida com base em material já elaborado, constituído principalmente de livros e artigos científicos. GIL (2002, p. 44)

Quanto às fontes de informação, a pesquisa foi bibliográfica e de campo. Utilizou-se a pesquisa de campo na construção desta monografia, visto que foram colhidas informações por observação do produto e do comportamento da 
concorrência, bem como foram avaliados os possíveis clientes potenciais, além de informações colhidas em livros, periódicos e documentos públicos.

\subsection{MÉTODOS DE ABORDAGEM}

a) Método Indutivo:

Para Marconi e Lakatos (2000, p. 53):

Indução é um processo mental por intermédio do qual, partindo de dados particulares, suficientemente constatados, infere-se uma verdade geral ou universal, não contida nas partes examinadas. Portanto, o objetivo dos argumentos é levar a conclusões cujo conteúdo é muito mais amplo do que o das premissas nas quais se basearam. Uma característica que não pode deixar de ser assinalada é que o argumento indutivo, da mesma forma que o dedutivo, fundamenta-se em premissas.

Ainda segundo Marconi e Lakatos (2000, p. 54), o método indutivo divide-se em três fases: observação dos fenômenos, descoberta da relação entre eles e generalização da relação.

b) Método Dedutivo: "que partindo das teorias e leis, na maioria das vezes prediz a ocorrência dos fenômenos particulares (conexão descendente)". (MARCONI e LAKATOS, 2001, p. 106).

c) Método Hipotético-dedutivo: que se inicia pela percepção de uma lacuna nos conhecimentos acerca da qual formula hipóteses e, pelo processo de inferência dedutiva, teste a predição da ocorrência de fenômenos abrangidos pela hipótese. (MARCONI e LAKATOS, 2001, p. 106).

d) Método dialético: "que penetra o mundo dos fenômenos através de sua ação recíproca, da contradição inerente ao fenômeno e da mudança dialética que ocorre na natureza e na sociedade". MARCONI e LAKATOS (2001, p. 106). 
O método de abordagem escolhido nesse trabalho foi o método dedutivo, pois, partindo das teorias e conceitos gerais da área, analisou-se aspectos específicos de organizações do mercado turístico.

\subsection{MÉTODOS DE PROCEDIMENTOS}

a) Histórico:

O método histórico consiste em investigar acontecimentos, processos e instituições do passado para verificar sua influência na sociedade de hoje, pois as instituições alcançaram sua forma atual por meio de alterações de suas partes componentes, ao longo do tempo, influenciadas pelo contexto cultural particular de cada época. MARCONI e LAKATOS (2000, p. 91).

b) Comparativo:

Considerando que o estudo das semelhanças e diferenças entre diversos tipos de grupos, sociedades ou povos contribui para uma melhor compreensão do comportamento humano, este método realiza comparações com a finalidade de verificar similitudes e explicar divergências. O método comparativo é usado tanto para comparações de grupos no presente, no passado, ou entre os existentes e os do passado, quanto entre sociedades de iguais ou de diferentes estágios de desenvolvimento. MARCONI e LAKATOS (2000, p. 92).

c) Estatístico:

O papel do método estatístico é, antes de tudo, fornecer uma descrição quantitativa da sociedade, considerada como um todo organizado. Por exemplo, definem-se e delimitam-se as classes sociais, especificando as características dos membros dessas classes e, após, mede-se sua importância ou variação, ou qualquer outro atributo quantificável que contribua para seu melhor entendimento. No entanto a estatística pode ser considerada mais do que apenas um meio de descrição racional; é, também, um método de experimentação e prova, pois é método de análise. MARCONI e LAKATOS (2000, p. 93). 
d) Monográfico:

O método monográfico consiste no estudo de determinados indivíduos, profissões, condições, instituições, grupos ou comunidade, com a finalidade de obter generalizações. A investigação deve examinar o tema escolhido, observando todos os fatores que influenciaram e analisando-o em todos os seus aspectos. MARCONI e LAKATOS (2000, p. 92).

e) Tipológico:

Apresenta certas semelhanças com o método comparativo. Ao comparar fenômenos sociais complexos, o pesquisador cria tipos ou modelos ideais, construídos a partir da análise de aspectos do fenômeno. A característica principal do tipo ideal é não existir na realidade, mas servir de modelo para a análise e compreensão de casos concretos, realmente existentes. MARCONI e LAKATOS (2000, p. 93).

f) Estruturalista:

O método parte da investigação de um fenômeno concreto, eleva-se, a seguir, ao nível abstrato, por intermédio da constituição de um modelo que represente o objeto de estudo, retornando, por fim, ao concreto, dessa vez como uma realidade estruturada e relacionada com a experiência do sujeito social. MARCONI e LAKATOS (2000, p. 95).

g) Funcionalista:

Levando-se em consideração que a sociedade é formada por partes componentes, diferenciadas, inter-relacionadas e interdependentes, satisfazendo cada uma das funções essenciais da vida social, e que as partes são mais bem entendidas compreendendo-se as funções que desempenham no todo, o método funcionalista estuda a sociedade do ponto de vista da função de suas unidades, Isto é, como um sistema organizado de atividades. MARCONI e LAKATOS (2000, p. 94).

O método monográfico foi o utilizado na elaboração deste estudo, pois houve uma análise geral em organizações e grupos de pessoas. 


\subsection{TÉCNICAS DE PESQUISA}

Pesquisa Quantitativa: O método quantitativo na pesquisa científica está sempre associado à experimentação e manipulação de um objeto estudado em uma população ou universo. Oliveira (2000, p. 68).

Pesquisa Qualitativa: "As pesquisas qualitativas caracterizam-se pela utilização de metodologias múltiplas, sendo as mais utilizadas a observação (participante ou não), a entrevista em profundidade e a análise de documentos". DENCKER (2004, p. 103).

OLIVEIRA (2000, p. 61) observa a diferença entre método qualitativo, que é "racional e subjetivo", e método quantitativo, "experimental e objetivo".

a) Entrevistas: Segundo DENCKER (2004, p. 136) entrevista é:

Uma comunicação verbal entre duas ou mais pessoas, com um grau de estruturação previamente definido, cuja finalidade é a obtenção de informações de pesquisa (receber informações relacionadas com a atividade turística por exemplo).

b) Questionários: "A finalidade do questionário é obter, de maneira sistemática e ordenada, informações sobre as variáveis que intervêm em uma investigação, em relação a uma população ou amostra determinada". DENCKER (2004, p. 146).

c) Observação assistemática: Segundo DENCKER (2004, p. 103) "Fazer pesquisa é observar a realidade". E ainda, sobre observação assimétrica, diz: "A observação não-estruturada (assimétrica) procura registrar os fenômenos como e na medida em que ocorrem e onde 0 pesquisador assume o papel no grupo observado". DENCKER (2004, p. 103). MARCONI e LAKATOS (2001, p. 107), sobre observação esclarecem: "utiliza os sentidos na obtenção de determinados aspectos da realidade. Não consiste apenas em ver e ouvir, mas também em examinar fatos e fenômenos que se deseja estudar".

Abaixo estão algumas técnicas de observação assistemática: 
- História de vida: "tenta obter dados relativos à experiência íntima de alguém que tenha significado importante para o conhecimento do objeto de estudo". MARCONI e LAKATOS (2001, p. 107).

- Pesquisa de mercado: "é a obtenção de informações sobre o mercado, de maneira organizada e sistemática, tendo em vista ajudar o processo decisivo nas empresas, minimizando a margem de erros." MARCONI e LAKATOS (2001, p. 106).

A técnica de pesquisa utilizada na construção dessa monografia foi a observação assistemática, visto que as informações foram colhidas por meio de observações nas empresas em dias e horários variados.

\subsection{UNIVERSO DE PESQUISA}

Nessa pesquisa foram analisados o setor de eventos da cidade de Dourados - em especial três das principais organizações de eventos sociais (formaturas e casamentos) -, bem como os principais fornecedores para cada tipo de evento, e também as seis instituições de ensino superior citadas, como parceiras.

\subsubsection{Técnicas de amostragem:}

De modo geral, os levantamentos abrangem um universo de elementos tão grande que se torna impossível considerá-los em sua totalidade. Por essa razão, o mais freqüente é trabalhar com uma amostra, ou seja, com uma pequena parte dos elementos que compõem o universo. GIL (2002, p. 121). 
A seguir, a conceituação dos tipos de amostragem, segundo GIL (2002, p. 121):

a) Aleatória simples:

Também é conhecida por amostragem casual, randômica, acidental etc. Consiste basicamente em atribuir a cada elemento do universo um número único para, depois, selecionar algum desses elementos de maneira casual. GIL (2002, p. 121)

b) Sistemática:

E uma variação de amostragem aleatória simples. Sua aplicação requer que a população seja ordenada de modo tal que cada um de seus elementos possa ser unicamente identificado pela posição. Apresenta condições para satisfação desse requisito uma população identificada a partir de uma lista que englobe todos os seus elementos, uma fila de pessoas ou o conjunto de candidatos a um concurso identificados pela ficha de inscrição. GIL (2002, p. 122).

c) Estratificada:

Caracteriza-se pela seleção de uma amostra de cada subgrupo da população considerada. O fundamento para delimitar os subgrupos ou estratos pode ser encontrado em propriedades como sexo, idade ou classe social. GIL (2002, p. 122).

d) Por conglomerados:

É indicada em situações em que é bastante difícil a identificação de seus elementos. É o caso, por exemplo, de pesquisa cuja população seja constituída por todos os habitantes de uma cidade. Em casos desse tipo, é possível proceder-se à seleção da amostra a partir de "conglomerados", Conglomerados típicos são quarteirões, famílias, organizações, edifícios, fazendas, etc. GIL (2002, p. 123).

e) Por cotas:

Este tipo de amostragem é muito utilizado em pesquisas eleitorais e de mercado, tendo como principal vantagem seu baixo custo. De modo geral, é desenvolvida em três fases: (I) classificação da população em função de propriedades tidas como relevantes para o fenômeno a ser estudado; (II) determinação da proporção da população a ser colocada em cada classe com base na constituição conhecida ou presumida da população; e (III) fixação de cotas para 
cada entrevistador encarregado de selecionar elementos da população a ser pesquisada de modo tal que a amostra total seja composta em observância à proporção das classes consideradas. GIL (2002, p. 123).

Nesse trabalho foram utilizadas as seguintes técnicas de amostragem: num momento, o método sistemático, uma vez que o universo específico o qual foi tirada a amostra - ou seja, a concorrência -, foi submetido aos critérios "qualidade" e "demanda de serviços", e, em outra ocasião, o método aleatório simples, cujos universos específicos - parceiros e fornecedores - foram escolhidos simplesmente pela facilidade de acesso, já que outras empresas dificultaram a consulta. 


\section{REFERENCIAL TEÓRICO}

\subsection{TURISMO}

O estudioso unindo teoria e prática, o aventureiro descobrindo a natureza, o peregrino em busca de sua fé, o trabalhador e sua família almejando descanso: considerando o homem um ser em busca dos seus objetivos, nota-se que há grande diversidade motivacional para seu deslocamento. Porém, o fator comum entre essas pessoas distintas é a fuga do cotidiano, é conhecer o novo e contemplar paisagens, sem preocupações nem minúcias externas que possam dificultar 0 total aproveitamento do que se oferece.

Tanto se fala em fazer o turismo, em pensar o turismo; mas para isso faz-se necessária a apresentação de alguns conceitos.

De acordo com a Organização Mundial do Turismo (OMT, 2006), turismo se traduz como: "as atividades que as pessoas realizam durante suas viagens e permanência em lugares distintos dos que vivem, por um período de tempo inferior a um ano consecutivo, com fins de lazer, negócios e outros".

Em uma conceituação mais profunda, De La Torre (1992, p.19) (Trad. do autor), declara:

O turismo é um fenômeno social, que consiste no deslocamento voluntário e temporário de indivíduos ou grupos de pessoas que, fundamentalmente por motivos de recreação, descanso, cultura ou saúde, saem do seu local de residência habitual para outro, no qual não exercem nenhuma atividade lucrativa nem remunerada, gerando múltiplas inter-relações de importância social, econômica e cultural.

E ainda ressalta: "o turismo é o meio mais nobre para conhecer, compreender e começar entre os homens e entre os povos". (De La Torre,1992, p.19). 
Nessa socialização do turismo, o qual permite o contato humano com o próximo e com o ambiente, a UNESCO - Organização das Nações Unidas para a Educação, a Ciência e a Cultura - defende a atividade turística como "um dos elementos primordiais para a consolidação da paz entre os povos, uma vez que o fluxo de turistas faz crescer sentimentos de amizade, respeito e cooperação entre países e entre populações de uma mesma nação".

Há uma diversa gama conceitual sobre turismo. Entretanto, é evidente a essência comum das definições na relação deslocamento, prazer ou necessidade, e a satisfação do viajante e contemplador.

\subsubsection{Planejamento do turismo}

É perceptível a necessidade de um planejamento vital, onde, ao amanhecer ou mesmo no dia anterior, o dia do individuo já está planejado pelo inconsciente, para que o possibilite de concretizar suas tarefas em tempo ideal.

Assim, Casasola (2003, p. 84) define planejamento como: "um conjunto de métodos e instrumentos que serve às sociedades para avançar em seu desenvolvimento socioeconômico".

Segundo Chiavenato (1987) apud Petrocchi (2002, p. 67):

O planejamento costuma figurar como a primeira função administrativa, por ser exatamente aquela que serve de base para as demais. O planejamento é a função administrativa que determina antecipadamente $o$ que se deve fazer e quais os objetivos que devem ser atingidos. O planejamento é um modelo teórico para ação futura. Visa dar condições para que o sistema seja organizado e dirigido a partir de certas hipóteses acerca da realidade atual e futura. O planejamento é uma atividade desenvolvida de maneira consistente para dar continuidade às atividades, e seu focus principal é a consideração objetiva do futuro.

E ainda o mesmo autor considera que:

[...] O planejamento é um processo que começa com a determinação de objetivos. Define estratégias, políticas e detalha planos para consegui-los; estabelece um sistema de decisões e inclui uma 
revisão dos objetivos para alimentar um novo ciclo de planificação. (CHIAVENATO, 1987 apud PETROCCHI 2002, p. 67).

O planejamento do turismo se torna indispensável para que, de forma organizada, desenvolva-se a atividade em determinado local, e os impactos positivos se sobressaiam-se aos negativos, trazendo, assim, melhoria econômica e social à comunidade.

Quanto à ausência do planejamento do turismo, Ruschmann (2001, p. 163) observa:

O maior problema da ausência do planejamento em localidades turísticas reside no seu crescimento descontrolado, que leva à descaracterização e à perda da originalidade das destinações que motiva o fluxo dos turistas, e o empreendimento de ações isoladas, esporádicas, 'eleitoreiras' e desvinculadas de uma visão ampla do fenômeno turístico.

Para se planejar o turismo, segundo a OMT, é necessário que os departamentos do governo, as associações nacionais de turismo e as organizações comerciais se unam para: 1) Trabalhar em conjunto com as autoridades de planejamento locais e regionais, para conscientização dos danos de um planejamento deficiente; 2) Orientar as autoridades locais quanto ao turismo sustentável e seus elementos a serem implantados, em um desenvolvimento turístico sustentável; 3) monitorar o desenvolvimento turístico em áreas de proteção ou muito sensíveis; 4) Garantir a implantação dos regulamentos, das medidas e das diretrizes de planejamento; 5) Auxiliar o governo local na análise de aptidão do atrativo em relação a disponibilidades dos recursos básicos, como terra, água, energia, infra-estrutura, etc, além dos fatores ambientais e culturais.

O desenvolvimento do turismo tem o propósito de melhorar as condições socioeconômicas da comunidade, incentivando a sustentabilidade na atividade e no meio social, promovendo, assim, prosperidade à sociedade. 


\subsubsection{Turismo de eventos}

Para um melhor entendimento desse segmento da atividade do turismo, fazse necessário o conhecimento de alguns conceitos. Para Andrade (1992) apud Matias (2004, p. 40), turismo de eventos é:

O conjunto de atividades exercidas por pessoas que viajam a fim de participar dos diversos tipos de eventos que visam ao estudo de alternativas, de dimensionamento ou de interesses de determinada categoria profissional, associação, clube, crença religiosa, corrente científica ou outra organização com objetivos nos campos científicos, técnicos e religiosos para atingir metas profissionais e culturais, técnicos e operacionais, de aperfeiçoamento setorial ou de atualização.

Enfatizando a segmentação, Britto e Fontes (2002, p. 30) conceituam:

É o segmento de turismo que cuida dos vários tipos de eventos que se realizam dentro de um universo amplo e diversificado. São congressos, conferências, cursos, exposições, feiras, shows, simpósios, solenidades, etc., que refletem o esforço mercadológico dos diversos segmentos, tais como as áreas médicas e de saúde, culturais, econômicas, jurídicas, artísticas, esportivas e comerciais, ao ingressarem em seus mercados potenciais com novas tecnologias, descobertas científicas e produtos.

Esses autores ainda observam:

A realização desses eventos vem proporcionar ao grupo de profissionais de uma mesma área a troca de informações, a atualização de tecnologias, o debate de novas proposições, o lançamento de um novo produto (cultural, histórico, social, industrial, comercial), que se constituem no melhor desempenho do grupo de interesse em questão. Promovendo a interação dessas pessoas, contribui-se para a geração e o fortalecimento das relações sociais, industriais, culturais e comerciais, ao mesmo tempo em que são gerados fluxos de deslocamento e visitação. (BRITTO E FONTES, 2002, p. 30).

Os eventos, movimentando a cadeia produtiva do turismo, são capazes de fomentar o desenvolvimento local, gerar e promover conhecimento, além de momentos de lazer para turistas e comunidade receptora. Britto e Fontes (2002, p. 39) esclarecem melhor a importância da promoção de eventos: 
O evento, ao se desenvolver e distribuir os fluxos turísticos, estará cumprindo o papel econômico do turismo, aumentando o número de ocupação nos meios de transporte, diminuindo a ociosidade dos meios de hospedagem, movimentando restaurantes, casas de diversões, favorecendo a distribuição de renda e possibilitando o efeito multiplicador do turismo.

Em se tratando de turismo e economia, é visível a geração de divisas e empregos advindos dessa atividade. O segmento de eventos contribui, em grande parte, para o desenvolvimento econômico e social do país, como demonstram os dados do artigo da EMBRATUR (2006):

O segmento de Turismo de Eventos é um dos que mais cresce no mundo, movimentando cerca de US\$ 4 trilhões anualmente. No Brasil, o setor envolve cerca de 80 milhões de participantes, gerando 2,9 milhões de empregos diretos e indiretos, causando impacto em 56 setores da economia. Estima-se que este ramo de atividade tenha crescido $7 \%$ anualmente no país nos últimos anos. Aproximadamente 327 mil eventos e 160 grandes feiras acontecem por ano no Brasil.

\subsubsection{Os Eventos}

Entende-se por evento a reunião de pessoas em qualquer área profissional ou não, com qualquer intuito, seja ele profissional ou lazer.

Para Andrade (1999, p. 117), evento é a "atividade dos mais diferentes tipos reunindo pessoas".

Conforme Gilda Fleury Meirelles (2006) ${ }^{1}$, "O evento é um instrumento de aproximação, de contigüidade física entre os participantes, com a otimização da comunicação oral, escrita, visual e interpessoal".

Para um melhor entendimento da atividade de organização e promoção de eventos, se faz necessário o conhecimento dos seus variados tipos e as áreas de interesse.

\footnotetext{
${ }^{1}$ Artigo retirado do site da IBRADEP - Instituto Brasileiro de Desenvolvimento, Aperfeiçoamento e Capacitação Profissional.
} 
Em relação à área de interesse dos eventos, Matias (2004, p. 76) classificaos como:

- $\quad$ Artístico - relacionado a qualquer manifestação de arte ligada à música, pintura, poesia, literatura e outras;

- Científico - trata de assuntos referentes às ciências naturais e biológicas, como por exemplo, medicina, botânica e outros;

- $\quad$ Cultural - ressalta os aspectos de determinada cultura, para conhecimento geral ou promocional;

- Cívico - trata de assuntos ligados à pátria;

- Desportivo - ligado a qualquer tipo de evento do setor esportivo, independente de sua modalidade;

- $\quad$ Folclórico - trata de manifestações de culturas regionais de um país, abordando lendas, tradições, hábitos e costumes típicos;

- Lazer - proporciona entretenimento ao seu participante;

- $\quad$ Promocional - promove um produto, pessoa, entidade ou governo, quer seja promoção de imagem ou apoio ao marketing;

- $\quad$ Religioso - trata de assuntos religiosos, seja qual for o credo;

- Turístico - explora os recursos turísticos de uma região ou país, por meio de viagens de conhecimento profissional ou não.

Meirelles (1999, p. 28), sobre tipologia dos eventos por área de interesse, ainda acrescenta:

- Educativo: o objetivo final é a educação;

- Informativo: objetiva somente fornecer informação, sem pretensões educativas ou culturais;

- $\quad$ Empresarial: trata de realizações das organizações;

- Social: visa somente a confraternização entre as pessoas;

E, quanto a sua tipologia básica, segundo Matias (2004, p. 77), resumidamente eles podem ser:

- Assembléia: reunião da qual participam delegações representantes de grupos, estados, países etc. Sua principal característica é debater assuntos de grande interesse de grupos, de classes profissionais, de países, regiões ou estados.

- Brainstorming: reunião desenvolvida para estimular a produção de idéias. Reúne pessoas que irão emitir suas idéias livremente sobre determinado assunto. Divide-se em duas 
etapas: a criativa e a avaliativa. A primeira é aquela em que os participantes expõem suas idéias, sem qualquer tipo de censura ou crítica. A segunda é quando as idéias coletadas são discutidas e analisadas propiciando traçar um perfil do objetivo pretendido.

- $\quad$ Brunch: trata-se de um café da manhã e almoço. O sucesso do brunch está na forma equilibrada como são servidos doces, salgados, sucos e bebidas alcoólicas leves. A origem da palavra brunch vem da junção de breakfast (café da manhã) e lunch (almoço).

- Colóquio: reunião fechada que visa esclarecer determinado tema ou tomar alguma decisão. Geralmente desenvolve-se da seguinte forma: é sugerido um tema central em que o plenário deve ser agrupado por subtemas. As discussões são conduzidas por um moderador, responsável pela apresentação das conclusões e por submetê-las à aprovação do plenário.

- Concílio: reunião de prelados católicos, na qual são tratados assuntos dogmáticos, doutrinários ou disciplinares.

- Conclave: evento de caráter religioso em que são discutidos termos de ordem ética e moral. A organização é semelhante a congressos.

- Concurso: sua principal característica é a competição, podendo ser aplicado a diversas áreas: artística, cultural, desportiva, científica e outras.

- Conferência: caracteriza-se pela apresentação de um tema informativo (geral, técnico ou científico) por autoridade em determinado assunto para um grande número de pessoas. É uma reunião bastante formal, exigindo a presença de um presidente de mesa que coordenará os trabalhos.

- Congresso: reuniões promovidas por entidades associativas que visam debater assuntos de interesse de determinado ramo profissional. Os congressos também podem ser de âmbito internacional, nacional, regional, estadual e municipal. As sessões de trabalho dos congressos são divididas em vários outros tipos de evento: mesa-redonda, conferência, simpósio, comissões, painéis, palestras, debates.

- Convenção: reunião promovida por empresas, setores industriais (vendedores) e partidos políticos, para lançamento de um novo produto ou plano de expansão no mercado. Outros tipos de convenção podem ser realizados, como convenções para congraçamento, comemorativas, de fim de ano, etc. Todas as convenções buscam a integração das pessoas pertencentes a uma determinada empresa ou partido político, submetendo-se a certos estímulos coletivos para que possa agir em defesa dos interesses da referida empresa ou partido.

- Coquetel: reunião de pessoas cujo objetivo é a comemoração de alguma data ou acontecimento. Nesse tipo de eventos são oferecidos bebidas e canapés, que devem ser servidos de forma adequada para satisfazer a maioria. É um evento de curta duração, nunca devendo ultrapassar uma hora e meia. 
- Debate: discussão entre dois oradores, cada um defendendo um ponto de vista. Existe a necessidade de um moderador para a coordenação do debate. Pode ser aberto ao público ou transmitido por veículo de mídia, entretanto a platéia nunca participa com perguntas.

- Desfile: evento que se classifica na categoria promocional. As condições básicas para seu sucesso são a escolha adequada dos convidados, dos produtos a serem mostrados, dos manequins (demonstradores), da trilha sonora e uma divulgação eficiente.

- Encontro: reunião de pessoas de uma categoria para debater sobre temas antagônicos, apresentados por representantes de grupos participantes, necessitando de um coordenador para resumir e apresentar as conclusões dos diversos grupos.

- Entrevista coletiva: evento no qual um especialista ou representante da empresa, entidade ou governo se coloca à disposição para responder sobre determinado assunto de seu conhecimento; os questionadores são a imprensa.

- Exposição: exibição pública de produção artística, industrial, técnica ou científica. Pode haver, ou não, objetivo de venda dos produtos expostos.

- $\quad$ Feira: Exibição pública com o objetivo de venda direta ou indireta, constituída de vários estandes, montados em lugares especiais, onde se colocam produtos e serviços.

Podem ser:

- Feiras comerciais: tem a finalidade de promover e vender.

- Feiras industriais: exibem bens e serviços para a indústria de transformação.

- Feiras promocionais: dirigida a um grupo específico ou profissional, onde são expostos serviços, equipamentos ou materiais relacionados diretamente à relação do grupo.

- Fórum: reunião que visa conseguir efetiva participação de um público numeroso, a fim de obter mais informação sobre determinado tema proposto. Permite aos interessados (técnicos e especialistas) debater com liberdade seus pontos de vista a respeito de temas em pauta, em busca de consenso geral.

- Happy hour: reunião de fim de tarde (coquetel / drinque), promovida por bares e restaurantes, caracterizada por disputas (dados, palitinho, dominó e outras) entre maîtres e clientes, nas quais quem ganha não paga a conta.

- Jornada: encontros de grupos profissionais, de âmbito regional, para discutir assuntos de interesse comum.

- Megaevento: evento de lazer e turismo em larga escala, como os Jogos Olímpicos ou as feiras mundiais. Está associado a criação de infra-estrutura e comodidades para o evento. Um 
megaevento, se bem sucedido, projeta nova (ou talvez renovada) e persistente imagem positiva da cidade-hóspede por meio da mídia nacional e internacional.

- $\quad$ Mesa-redonda: reunião questionadora de um grupo de quatro a oito pessoas, sentadas em semicírculo, as quais debatem um assunto controvertido e de interesse público. Um moderador coordena os trabalhos, e o plenário pode ou não participar por intermédio de perguntas.

- Mostra: exposição itinerante.

- Oficina: semelhante ao workshop. TIPO DE EVENTO mais utilizado pela área educacional, porque proporciona a construção do conhecimento, enquanto o workshop destina-se mais à área empresarial, pois visa a demonstração de produtos.

- $\quad$ Painel: tipo de reunião derivado da mesa-redonda. Tem como objetivo reproduzir as informações de um pequeno grupo para um grande grupo assistente, permitindo vários ângulos da situação proposta. A estrutura do painel é composta de um orador e quatro painelistas que se apresentam sob a coordenação de um moderador.

- Palestra: menos formal que a conferência, caracteriza-se pela apresentação de um tema predeterminado a um grupo pequeno, que já possui noções sobre o assunto. É coordenada por um moderador e permite a intervenção dos participantes durante a exposição.

- Roda de negócios: reunião que tem por objetivo aproximar empresas para realizar parcerias e negociar seus produtos e serviços, ou concluir uma negociação político-econômica.

- Roadshow: consiste na demonstração itinerante, montada sobre um ônibus ou carreta, que se desloca para áreas geoeconômicas de determinado país ou estado, com o objetivo de informar e mostrar potencial de uma organização, governo ou entidade por meio de apresentação de fotos, gráficos, livros, protótipos de produtos e vídeo, visando conquistar novos clientes, associados ou parceiros e obter o apoio do público.

- Salão: destinado a promover e divulgar produtos e informar sobre eles, com intuito de criar para os consumidores uma imagem positiva da instituição promotora.

- Semana: Visa discutir temas de interesse comum. Segue o mesmo esquema do congresso, com palestras, conferências e painéis.

- Seminário: exposição verbal, cujos participantes possuem conhecimento prévio do assunto a ser exposto. Seu propósito é fornecer e somar informações de temas já pesquisados. Dividese da seguinte forma:

- Fase de exposição: quando alguém previamente escalado, realiza uma pesquisa e leva sua contribuição para o grupo. 
Fase da discussão: quando o assunto em pauta é debatido e detalhado em todos os seus aspectos.

- Fase da conclusão: quando um coordenador, polarizando as opiniões dominantes, propõe as recomendações finais do seminário à aprovação do grupo.

- Showcasing: evento lançado recentemente no Brasil, como uma alternativa para feiras. O showcasing insere o conceito de vitrine interativa. Os produtos ou serviços são expostos em vitrines fechadas, e os participantes não têm nenhum contato direto com os expositores. A comunicação ocorre por intermédio de telefones instalados nas cabines e conectados diretamente a uma central de informação.

- Simpósio: reunião derivada da mesa-redonda que possui como característica apresentar alto nível de qualidade e contar com a participação de renomados especialistas. A diferença fundamental entre simpósio e mesa-redonda é que no simpósio os expositores não debatem entre si o tema apresentado.

- Videoconferência ou teleconferência: novo meio de organizar evento por uma linha de satélites e um espaço físico adequado, que permitem a interação entre os participantes. As vantagens desse tipo de evento são: encurtar distâncias, racionalizar diálogos, reduzir investimentos, acelerar a troca de informações entre pessoas oU empresas.

- Visita ou open day: reunião usada pelos meios empresariais para mostrar os sistemas, métodos, equipamentos e materiais a determinado segmento de público.

- Workshop: grupo de trabalho ou oficina. É uma reunião de especialistas para apresentação de novas técnicas, desenvolvimento de novos temas.

- Outros eventos: inaugurações, shows, lançamentos, sorteios, rodeios, leilões, comícios, jantares etc.

\subsubsection{Eventos e cadeia produtiva do turismo}

A criação de um evento, desde a idéia até a execução, movimenta diversas áreas profissionais, como empresas de locação de equipamentos (vídeo, som, telefonia, informática, iluminação), equipes de montagem, decoração, segurança, 
gráfica para convites e publicidade, buffet, banda, disc jockey (DJ) ${ }^{2}$, animação, entre outros.

Britto e Fontes (2002, p. 35) fornecem-nos uma reflexão sobre os variados tipos de eventos:

Existe toda uma tipologia de eventos, já determinada, que os classifica de acordo com seus objetivos. Pode-se listá-los como: congressos, convenções, seminários, simpósios, mesas-redondas, painéis, fóruns, palestras, conferências, debates, feiras, exposições, encontros/jornadas, entre outros. Além dos mencionados, podem-se indicar eventos mais inusitados, tais como: shows, inaugurações, leilões, banquetes e outros.

Sobre movimentação da cadeia produtiva do turismo, os mesmos autores destacam ainda que:

Os eventos também possibilitam a ampliação de bens e serviços, uma vez que seus participantes aproveitam a viagem para a realização de passeios, compras de produtos típicos, etc., gastando mais do que o turista comum e gerando lucro para o núcleo receptor. (BRITTO e FONTES, 2002, p. 36).

Em se tratando dos principais elos da cadeia produtiva do turismo, o PROATUR - Programa de Apoio ao Turismo Regional (2004, item 2) -, destaca:

Podem-se enumerar várias atividades integrantes da cadeia produtiva do turismo que absorvem diretamente os efeitos multiplicadores do turismo, como por exemplo: hospedagem, transporte, alimentação, entretenimento, agenciamento, locação de veículos, câmbio de moedas, aquisição de produtos de conveniência e souvenirs, recepção, organização de eventos, intérprete e tradução simultânea, serviço de guia, informações turísticas, planejamento e consultoria turística, entre outros.

Percebe-se, então, que os setores envolvidos com a movimentação da atividade turística são muitos e diversificados, alcançando diferentes áreas e envolvendo um grande número de empresas - de pequeno e médio porte, formais ou informais -, e que a promoção de eventos se faz necessária também como contribuinte para o progresso do turismo local na baixa estação.

\footnotetext{
${ }^{2}$ Profissional responsável pela seleção e mixagem de música em pistas de dança e festas.
} 
3.1.2.3 Formatura e casamento (cerimonial, protocolo e etiqueta)

O cerimonial, protocolo e etiqueta, são termos que se interligam e que, de forma harmônica, são responsáveis pela beleza e plenitude do evento.

Para qualquer tipo de evento necessita-se de um cerimonial organizado e competente, e isso se faz imprescindivelmente aos eventos de formatura e também de casamento.

Citam-se aqui algumas definições dos termos:

Etiqueta social é o conjunto de regras, padrões e ética, a serem seguidos pela sociedade.

Para Britto e Fontes (2002, p. 131) cerimonial é a "rigorosa observância de certas formalidades em eventos oficiais, entre autoridades nacionais e estrangeiras; conjunto de formalidades de atos solenes e festas públicas.

E, ainda para os autores, protocolo é:

A ordem hierárquica que determina normas de conduta dos governos e seus representantes em ocasiões oficiais ou particulares. Codifica as regras do cerimonial com o objetivo de oferecer e privilegiar prerrogativas e imunidades a quem de direito e na ocasião adequada. (BRITTO e FONTES, 2002, p. 131).

É importante também observar as definições de cerimônia e solenidade.

Para Meirelles (1999, p. 22), cerimônia é "sinônimo de evento", e solenidade é "evento, no qual a pompa é a característica; sessão solene".

As formaturas basicamente se dividem nas seguintes sessões: religiosa (missa, culto ou culto ecumênico); colação de grau e baile de confraternização.

Sobre os eventos de formatura, Britto e Fontes (2002, p. 84) observam:

São eventos que incorporam a cerimônia de oficial e pública da colação de grau, sem a qual o aluno não receberá o título de bacharel e, consequentemente, o diploma universitário. Nesta cerimônia todos os formandos devem colar o grau de bacharel assinando a Ata de Colação de Grau oficial da instituição de ensino. 
A seguir, está um roteiro como alternativa a ser seguida no ato da sessão solene de colação de grau.

Roteiro de sessão solene de colação de grau (Bettega, 2001) apud Britto e Fontes (2002, p. 157):

Quadro 1: Roteiro de sessão solene de colação de grau

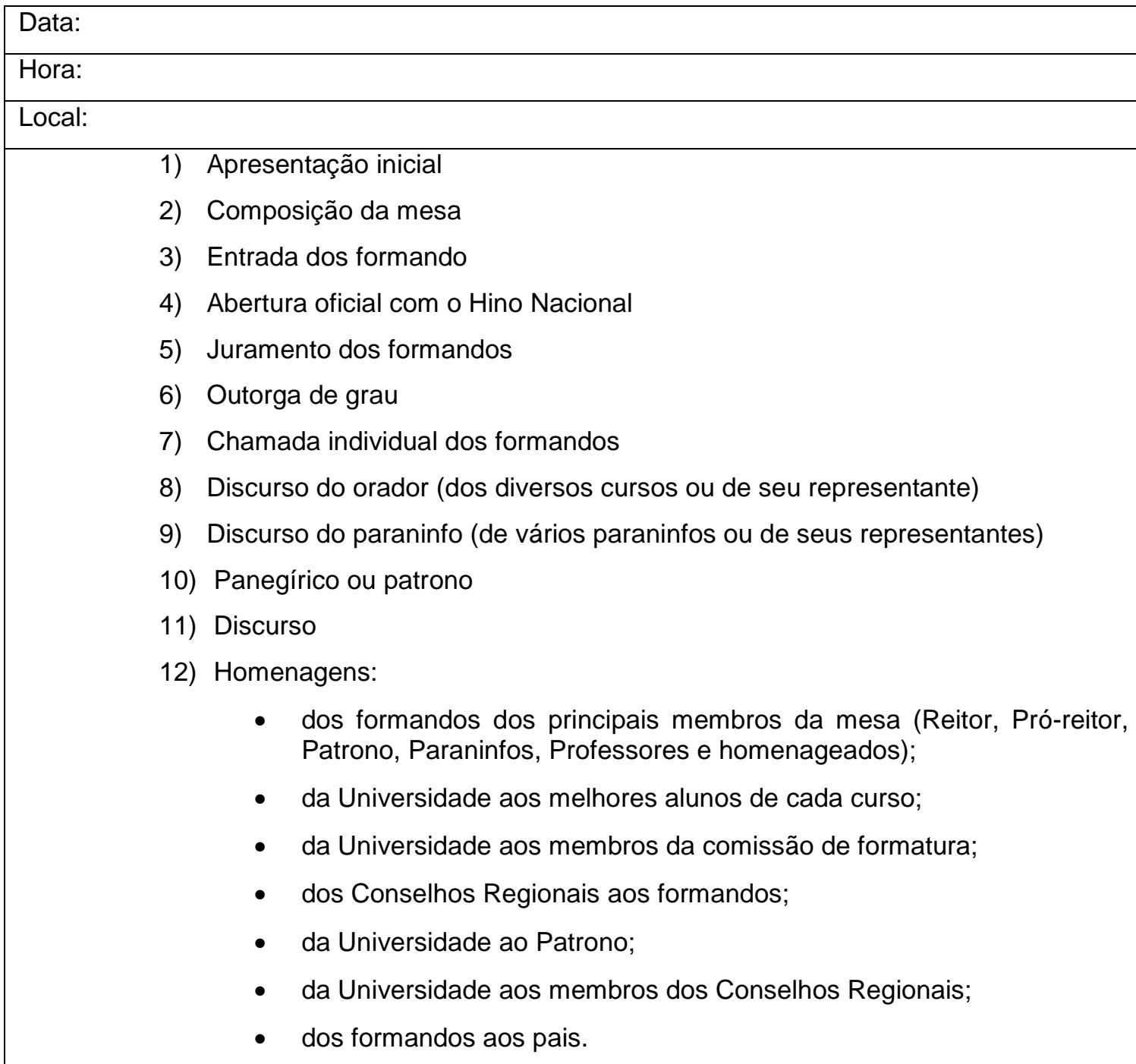

13) Livro de registro de Autoridades

O Reitor passa o Livro de Registro de Autoridades para a maior autoridade presente, a fim de deixar sua impressão sobre o evento. Os demais componentes da mesa poderão assinalar sua participação no livro, após o encerramento da cerimônia.

14) Agradecimentos

15) Encerramento da sessão solene

Fonte: (Bettega, 2001) apud Britto e Fontes (2002, p. 157)

Para a sessão solene de colação de grau, de acordo com Britto e Fontes (2002, p. 85): "Os formandos elegem seu representante oficial - um orador - que 
fará o discurso em nome dos alunos, o patrono e o paraninfo ou padrinho (madrinha) da turma e indicam (caso seja acordado entre todos) os docentes homenageados".

Sobre o desenvolvimento desse tipo de evento, os mesmos autores observam:

Esse evento é conduzido por um mestre de cerimônias, previamente escolhido pela Comissão de Formaturas, que fará a composição da mesa, segundo o cerimonial acadêmico, indicará os homenageados (alunos e docentes), convidará orador, patrono e paraninfo para proferirem seus discursos e homenagens e procederá a leitura dos nomes dos formandos, em ordem alfabética,para que estes assinem o livro e recebam certificados e congratulações. O encerramento da cerimônia é feito pela autoridade acadêmica de maior grau presente, agradecendo-se a presença dos pais, parentes e amigos. (BRITTO E FONTES, 2002, p. 85).

Quanto às cerimônias de casamento e bodas, essas são eventos sociais que exigem um planejamento especial por serem cerimônias únicas, pois é "nas bodas, [que] o casal renova seus votos de casamento, podendo ser ao lados dos filhos, netos e demais familiares" (Britto e Fontes 2002, p. 85).

O quadro a seguir demonstra os tipos de bodas de casamento, e os anos referentes a cada uma:

Quadro 2: Nomenclatura das bodas

\begin{tabular}{|c|c|}
\hline Número de anos & Nomenclatura \\
\hline 01 & Bodas de papel \\
\hline 02 & Algodão \\
\hline 03 & Couro \\
\hline 04 & Flores \\
\hline 05 & Ferro \\
\hline 06 & Cobre ou lã \\
\hline 07 & Bronze \\
\hline 08 & Pote de Madeira \\
\hline 09 & Estanho \\
\hline 10 & Aço \\
\hline 11 & Seda \\
\hline 12 & Renda \\
\hline 13 & Marfim \\
\hline 14 & Cristal \\
\hline 15 & \\
\hline
\end{tabular}




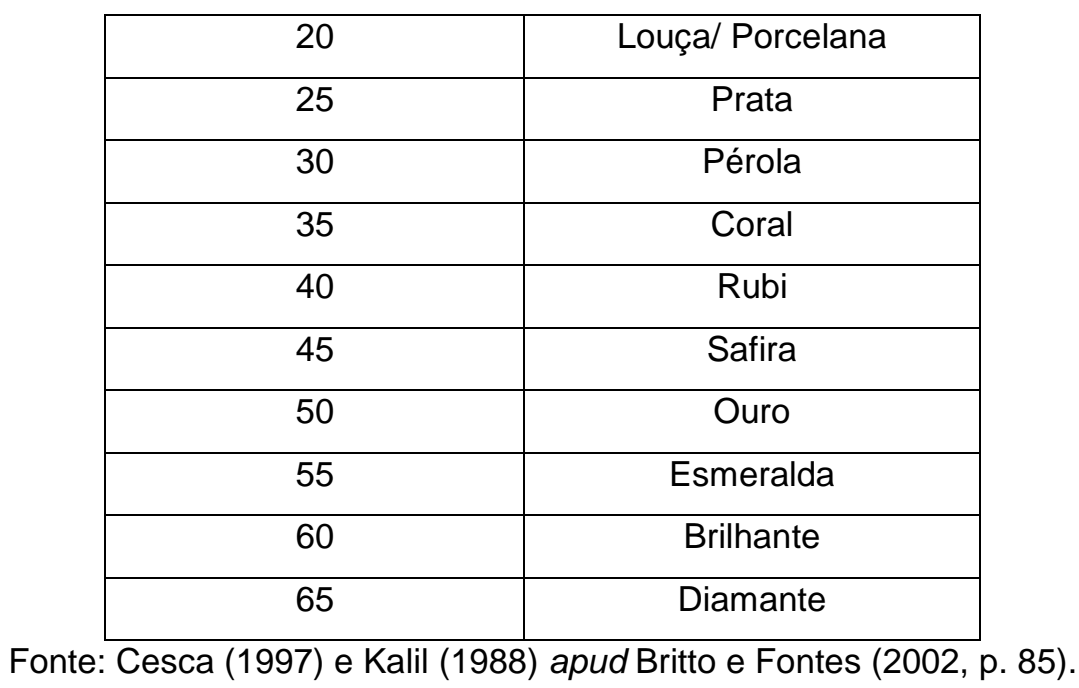

\subsection{PLANEJAMENTO ESTRATÉGICO}

"O planejamento estratégico é um processo que prepara você para o que está por vir" (Tiffany e Peterson, 1999, p. 09).

\subsubsection{Planejamento estratégico em organizações turísticas}

Para melhor compreensão do tema estudado nesse capítulo, encontram-se a seguir algumas referências conceituais

Sobre planejamento de uma forma geral, Petrocchi (2002, p. 66) destaca que:

O planejamento é uma das funções essenciais da administração. $\mathrm{Na}$ teoria neoclássica da administração, o planejamento articula-se no denominado ciclo administrativo, e suas funções são organizar, dirigir e controlar. Trata-se de um elemento fundamental para a sobrevivência das organizações. Para prever ações, escolher caminhos ou estabelecer processos de tomada de decisão, o 
planejamento precisa ter uma visão global do sistema e estudar cenários futuros.

Existem três tipos de planejamento: o estratégico, o tático e o operacional. A tabela abaixo, retirada da obra de Petrocchi (2002), explica a diferença entre cada um:

Quadro 3: Tipos de planejamento

\begin{tabular}{|c|c|c|c|}
\hline Tipos de planejamento & Abrangência & $\begin{array}{c}\text { Exposição ao } \\
\text { tempo }\end{array}$ & Nível de decisão \\
\hline Estratégico & $\begin{array}{c}\text { Organização como um } \\
\text { todo }\end{array}$ & Longo prazo & Alta administração \\
\hline Tático & Departamento ou setor & Médio prazo & Média gerência \\
\hline Operacional & Tarefa ou operação & Curto prazo & Supervisão \\
\hline
\end{tabular}

Fonte: Idalberto Chiavenato, 1987

Pela sua complexidade, o planejamento estratégico abrange o tático e operacional. Sobre isso, Kotler apud Pedrosa $(2004)^{3}$ afirma que "o planejamento estratégico é uma metodologia gerencial que permite estabelecer a direção a ser seguida, pela organização, visando maior grau de interação com o ambiente".

Salim et al (2005, p. 17) detalha o planejamento estratégico como:

Está associado a uma linha de atuação que visa atingir objetivos de longo prazo. Ele define qual o negócio da empresa, onde ela está hoje e onde quer chegar. Para isso, fixa macro objetivos que necessitam ser detalhados e compatibilizados com as possibilidades a cada ponto de sua execução.

Observa-se, então, que o planejamento estratégico é de grande relevância para manter o ciclo de vida da empresa, definindo objetivos e estratégias para alcançar o sucesso. Com empresas de turismo não é diferente. O cuidado maior, em evidência, é com a qualidade de seu produto, que se configura como um bem intangível, sendo necessário vendê-lo com cautela, pois a falta de planejamento e controle acabam atingindo de forma negativa os atrativos, o meio de hospedagem, ou o evento em si, podendo, assim, não alcançar as expectativas do consumidor - o

\footnotetext{
${ }^{3}<$ http://www.biblioteca.sebrae.com.br/bds/BDS.nsf/BD923291670360C703256F29004F48FE/\$File/Planejamento\%20estr at\%C3\%A9gico.pdf> Acesso em: 15 janeiro 2007.
} 
que trará, como feedback para a empresa introdutora de todo o trajeto, insegurança e falta de seriedade.

\subsubsection{Planejamento estratégico em empresas de eventos}

Como visto no capítulo anterior, o planejamento estratégico é necessário para a organização e manutenção dos setores da empresa, e em qualquer área de abrangência, seja vendendo produtos ou serviços.

Uma empresa de eventos vende serviços. Quanto à sua função no mercado, FTE - Faculdade de Tecnologia Empresarial - (2006, p. 172) destaca:

A função da empresa de Produções e de Promoções de Eventos é oferecer permanente orientação para suprir as necessidades de seus clientes, no que se refere Às demandas relativas a soluções de planejamento e a projetos de implementação de infra-estrutura gerada pelo mercado de eventos, suprindo sua avidez por informações e por serviços especializados. (FTE, 2006, p. 172)

E ainda sobre o papel da empresa de eventos, observa:

Ela deve funcionar como elemento facilitador entre promotores, fornecedores de equipamentos e serviços, patrocinadores, parceiros e consumidor final. Para alcançar-se bom desempenho do seu papel no mercado, a empresa deve caracterizar-se pela flexibilidade na oferta de seus bens intangíveis, como: conhecimento, soluções criativas e serviços específicos. (FTE, 2006, p. 172)

A organização da empresa, o clima organizacional e a energia do empreendimento refletem-se no produto final, que deve ser planejado levando-se em conta os mínimos detalhes, para que as pequenas falhas possam ser corrigidas com improvisações, alcançando e superando as expectativas do consumidor.

Segundo Meirelles (1999, p. 71) o planejamento é: "o fator fundamental ao desenvolvimento de qualquer atividade e, de modo especial, para a organização de 
eventos, permitindo a racionalização das atividades, o gerenciamento dos recursos disponíveis e a implantação do projeto".

Abaixo está uma listagem dos principais serviços das empresas de eventos, segundo FTE (2006, p.176):

- Planejamento logístico: Planejamento e controle detalhado de todas as tarefas relativas ao evento;

- Planejamento geral das atividades de obtenção, de armazenamento, de transporte, de distribuição e de montagem de equipamentos e de estruturas, de instalações em geral e de suprimentos em geral.

- Monitoração dos eventos: planejamento de manutenção preventiva e corretiva dos equipamentos, estrutura e instalações;

- Desenvolvimento de negócios;

- Pesquisa e criação de estruturas físicas e de soluções para eventos;

- Estudos Financeiros: estudo da movimentação financeira necessária para a realização dos eventos: elaboração de orçamentos, elaboração de demonstrativo de fluxo de caixa, simulação de resultados;

- $\quad$ Rede de Promotores de eventos: através da conexão com as diversas empresas que fazem parte do mercado da promoção e das produções artísticas e culturais, buscar melhores soluções e aplicações de preços, de prazos, de qualidade dos serviços, de pontualidade e de diferenciação.

3.2.2.1 O Profissional de Eventos - gestor

O dinamismo da produção de eventos exige muita atenção e precisão do profissional, que deve estar atento à peculiaridade de cada evento, e também sabedoria, para ajustá-lo ao ambiente programado para sua execução - clima, cultura local, espaço, entre outros.

Giácomo (1997) apud FTE (2006, p. 174) reflete sobre a gerência de um evento, quando afirma que 
(...) gerenciar um evento é uma excitante atividade administrativa, como se conduz um concerto de centenas de pormenores que devem surgir em harmonia e ritmo correto. Porque o que diferencia um evento medíocre de um acontecimento brilhante não está no custo e sim na forma como se consegue o equilíbrio entre a criatividade, o bom gosto e a precisão de seu gerenciamento.

A função do gestor de eventos é, precisamente, planejar, gerir, monitorar e avaliar os mínimos detalhes do acontecimento.

\subsubsection{Empreendedorismo}

A palavra empreendedorismo vem do termo francês entrepreneur, usada no século XII, significando aquele que incentivava brigas. Com o tempo, já no final do século XVIII, o termo passou a ser usado para indicar a pessoa que criava e conduzia projetos e empreendimentos.

O economista Cantillon (1755), foi o primeiro a definir significados e conceitos, defendia o termo empreendedorismo como sendo as pessoas que compravam matérias-primas para vender a terceiros, depois de manuseá-las, identificando então uma oportunidade de negócio e assumindo riscos. Jean-Baptiste Say (1803), também economista, com uma visão mais moderna, considerou que a criação de novos empreendimentos resultaria em desenvolvimento econômico.

Em se tratando do agente propulsor da atividade - o empreendedor -, Dolabela (1999, p. 44) destaca: "é alguém capaz de desenvolver uma visão, mas não só. Deve saber persuadir terceiros, sócios, colaboradores, investidores, convencê-los de que sua visão poderá levar todos a uma situação confortável no futuro".

E o mesmo autor ainda observa:

Ser empreendedor não é somente uma questão de acúmulo de conhecimento, mas a introjeção de valores, atitudes, comportamentos, formas de percepção do mundo e de si mesmo voltados para atividades em que o risco, a capacidade de inovar, 
perseverar e de conviver com a incerteza são elementos indispensáveis. (DOLABELA, 1999, p. 44)

Então, empreender é a capacidade de ter grandes idéias, ter atitude, aproveitar oportunidades, resolver problemas, criar inovando, sonhar e realizar.

\subsection{4 Ética empresarial}

A palavra ética, vinda do latim ethica, é um segmento da filosofia que defende a natureza do que possa ser adequado em um determinado grupo. A consciência moral do indivíduo, seguindo seus valores, julga suas ações, diferenciando o que é bom ou ruim, certo ou errado, justo ou injusto.

Para a definição do que é ser ético, usa-se o bom senso diante da sabedoria individual e crenças.

De acordo com Instituto Brasileiro de Ética Concorrencial apud Roberto Teixeira da Costa ${ }^{4}$

A ética é a peça central das regras sociais. Nos mercados, torna-se um pilar de vital significado para a igualdade de oportunidades, respeito aos limites legais e as proposições corretas dessa arte maior que é a imposição justa, motor do dinamismo e da vitalidade da economia, dos negócios e das empresas.

Sobre a ética, sua importância no meio dos negócios e a desvalorização das leis por empresário e funcionários, Joaquim Manhães Moreira apud Roberto Teixeira da Costa (2006) observa:

Deve-se considerar que o primeiro dever ético de qualquer pessoa ou organização é o de cumprir a lei. Para cumprir a lei é preciso conhecê-la. A empresa ética deve manter procedimentos que permitam aos seus administradores e empregados conhecer os textos legais relevantes, aplicáveis às suas atividades, inclusive aqueles que se referem às suas responsabilidades sociais.

\footnotetext{
${ }^{4}$ Artigo "As empresas e a ética" para o XVIII Fórum Nacional. Rio de Janeiro, maio de 2006, 13p
} 
Sobre questões éticas existentes nas pequenas empresas, Longenecker et al (1998, p. 669) observa:

Questões éticas são aquelas que envolvem questões sobre o que é certo e o que é errado. Esse tipo de questão vai muito além daquilo que é legal ou ilegal. Muitos relacionamento de pequenas empresas exigem decisões sobre o que é honesto ou desonesto, razoável ou não-razoável, respeitoso ou desrespeitoso.

É de grande relevância as empresas agirem com cautela, seguindo os princípios legais em seus procedimentos de negociação com clientes e fornecedores, e, em seu meio interno, com seus colaboradores. A compreensão da ética e do ser ético é de grande valia para se desenvolver um excelente trabalho, e assegurar o bom convívio social coletivo e pessoal. 


\section{PLANO DE NEGÓCIO}

Como já visto, o plano de negócio se refere ao caminho que a empresa seguirá para obter sucesso. Determina como e onde ela quer chegar. É um planejamento, onde se traça as estratégias a fim de minimizar custos e aumentar sua competitividade.

\subsection{PLANO ESTRATÉGICO}

"Todo plano estratégico precisa ter desafios, objetivos e metas a serem atingidos ao longo do horizonte de tempo de planejamento". (Costa, 2003, p. 199).

Todo plano estratégico deve ser criado baseado em questionamentos, como demonstra o quadro abaixo, formulado por Costa (2003, p.207): 
Quadro 4 - Perguntas necessárias para o plano estratégico

\begin{tabular}{|c|l|}
\hline Perguntas & \multicolumn{1}{c|}{ Comentários } \\
\hline O quê? & $\begin{array}{l}\text { O que deve ser feito, quais são os passos ou etapas necessários, } \\
\text { quais dependem de quais, e quais podem ser realizados } \\
\text { simultaneamente? }\end{array}$ \\
\hline Depende de quê? & $\begin{array}{l}\text { Esta atividade depende de qual? Qual ou quais etapas devem ser } \\
\text { completadas para que esta possa se iniciar? }\end{array}$ \\
\hline Quem? & $\begin{array}{l}\text { Quem deve executar cada atividade e quem deve supervisionar a sua } \\
\text { execução e responder por prazos, qualidade e orçamento de cada } \\
\text { etapa? }\end{array}$ \\
\hline Por quê? & $\begin{array}{l}\text { Justificativa: Por que a etapa específica é considerada necessária? } \\
\text { Uma simples justificativa ajuda muito no entendimento do projeto. A } \\
\text { impossibilidade ou a dificuldade em obter uma justificativa razoável é } \\
\text { uma boa indicação para um questionamento mais profundo, se aquela } \\
\text { etapa deve, mesmo, ser incluída no projeto. }\end{array}$ \\
\hline Como? & $\begin{array}{l}\text { Como a etapa deverá ser executada? É a maneira como será feita } \\
\text { cada etapa. }\end{array}$ \\
\hline Quanto custa? & Até quando aquela atividade deve ser completada? \\
\hline Ruanto vai custar a etapa, quanto será gasto para realizá-la? \\
necessários? & $\begin{array}{l}\text { Que outros recursos são necessários, em cada etapa, como recursos } \\
\text { humanos, informações, relatórios, licenças, patentes, equipamentos, } \\
\text { espaço físico, máquinas e tecnologias? }\end{array}$ \\
\hline
\end{tabular}

Fonte: Costa (2003, p.207)

Nesse trabalho de criação de uma empresa, os tópicos citados na tabela foram pensados e analisados cuidadosamente.

\subsubsection{Sumário Executivo}

O Sumario executivo é a apresentação da empresa. O objetivo dessa etapa do trabalho é "retratar a empresa e o negócio que se pretende empreender". (Salim et al, 2005, p. 42).

Este plano de negócios define como será a criação e o funcionamento da Supera Produções, empresa que organiza eventos sociais, tendo como principal foco os eventos de formatura, bodas, casamento e festa de debutante, que, 
organizados de acordo com as exigências do cliente, pretendem quebrar o tradicional, trazendo o que há de mais moderno e criativo para a festa.

\subsubsection{Objetivo do Plano}

O Objetivo desse plano de negócio é organizar idéias e traçar objetivos, de forma consistente e segura, para a implantação e desenvolvimento da empresa de eventos Supera Produções.

\subsubsection{Descrição do Negócio}

A Supera Produções atuará no setor de eventos sociais com criatividade e inovação, tendo sua sede localizada no município de Dourados, MS. O negócio terá como sócios Kellen Cruz Felizari (majoritária) - turismóloga, especialista em gestão de negócios em turismo -, e Giovanny Noceti Viana - mestre em história e professor de faculdades da região.

\subsubsection{Visão}

De acordo com a definição de Filion (1991) apud Dolabela (1999, p. 76)

Visão é uma imagem, projetada no futuro, do lugar que se quer ver ocupado pelos seus produtos no mercado, assim como a imagem projetada do tipo de organização necessária para consegui-lo. 
A visão envolve o sonho da organização, que, não necessariamente, precisa ser alcançado. A visão é projetada no futuro, deve ser ambiciosa e inspiradora. Embora simples, é determinante para o destino da empresa.

Levando em conta as definições acima para a criação da visão da empresa, pode-se afirmar que a visão da Supera Produções é:

Ser reconhecida em 4 anos na região como a melhor empresa realizadora de sonhos, organizando eventos e proporcionando momentos inesquecíveis aos clientes, superando expectativas.

\subsubsection{Missão}

Tomou-se como base a definição de Salim et al (2005, p. 44), onde ele diz que: "Missão da empresa é a função que ela vai exercer junto ao mercado, provendo-Ihe de produtos e/ou serviços".

A partir daí, a missão é a idéia de sucesso da empresa, é o que ela pretende ser e a razão dela existir.

Conforme Costa (2003, p.36), a formulação da missão deve responder às seguintes perguntas:

- Qual a necessidade básica que a organização pretende suprir?

- $\quad$ Que diferença faz para o mundo externo, ela existir ou não?

- $\quad$ Para que serve?

- Qual a motivação básica que inspirou seus fundadores?

- $\quad$ Por que surgiu?

Então, a missão da Supera Produções é:

Fornecer ao cliente produtos diferenciados, com alta qualidade e bom preço. Fazer de um evento, um acontecimento. De um sonho, uma realização. 


\subsubsection{Objetivos e metas}

\subsubsection{Objetivos}

"Objetivo é o alvo ou situação que se pretende atingir. Aqui se determina para onde a empresa deve dirigir seus esforços”. Oliveira (1997, p. 50).

- Conquistar a liderança no mercado regional

- Obter excelência nos serviços prestados

- Vender com melhor preço, qualidade e criatividade

\subsubsection{Metas}

"Meta corresponde aos passos ou etapas perfeitamente quantificadas e com prazos para alcançar os desafios e objetivos”. Oliveira (1998, p. 73).

Baseando-se nesse conceito, as metas da Supera Produções são as seguintes:

- Em 2 anos, obter grandes parcerias com 10 instituições de ensino para exclusividade dos serviços na cidade e região;

- Disponibilizar, em média, 2 cursos por ano para cada funcionário, nas áreas de interesse da empresa.;

- Em 2 anos, alcançar a produção de, pelo menos, 20 eventos por ano, aumentando 10 a cada ano. 


\subsubsection{FATORES CRÍTICOS DE SUCESSO}

Fatores críticos de sucesso são alguns poucos fatores que fazem a diferença entre o sucesso e o fracasso da empresa. (Salim et al, 2005, p. 45).

Abaixo estão os FCSs da empresa em questão:

- Estabelecimento de parcerias;

- $\quad$ Credibilidade e compromisso profissional;

- $\quad$ Capacitação de pessoal;

- $\quad$ Eficiência e qualidade nos serviços;

- Identificação e monitoramento da concorrência;

- $\quad$ Investimento em Inovação.

\subsubsection{Princípios e valores:}

Costa (2003, p. 39) observa: "Todas as organizações têm, explícita ou implicitamente, suas crenças básicas e as virtudes que querem exaltar". E quanto aos princípios afirma: "O princípios são aqueles pontos e tópicos que a organização não está disposta a mudar, aconteça o que acontecer".

Quanto aos valores, Costa (2003, p. 39) afirma:

Os valores são características, virtudes, qualidades da organização que podem ser avaliadas como se estivessem em uma escala, com gradação entre valores extremos. São atributos realmente importantes para a organização, virtudes que devem ser preservadas, meritizadas e incentivadas.

Os princípios e valores da organização em questão estão relacionados na sequência: 
a) Dedicação aos clientes

A Supera Produções tem o prazer e o compromisso de cuidar de cada cliente, construindo relações amistosas com profissionalismo, antecipando-se às suas necessidades para melhor servi-los.

b) Foco nos resultados

Comprometimento ao realizar o evento: sempre da melhor forma possível, de acordo com as necessidades e exigências do cliente, superando expectativas.

c) Respeito e ética

Respeito e ética fazem parte dos passos dados pela Supera Produções em sua trajetória. Uma comunicação sincera com funcionários e clientes, reconhecendo as diferenças de valores sociais e culturais individuais, independente do nível de instrução, sexo, etnia, posição financeira ou social, praticando a concorrência com ética e respeito, valores os quais, acima de tudo, nos encaminham ao desenvolvimento e otimização de nossos produtos.

d) Ambiente organizacional

Incentivar a criatividade, promover debates e maximizar os resultados, é a filosofia da empresa, que acredita em seus colaboradores como sendo grandes aliados para o sucesso. O ótimo relacionamento com o quadro de funcionários, independente do nível hierárquico, reflete-se na excelência de seus serviços, colaborando para a satisfação do cliente e a perpetuação do empreendimento.

\subsection{RESUMO DA EMPRESA}

Esse item do trabalho é muito importante, pois é dever do formulador do plano, aqui, identificar a oportunidade e transformá-la num negócio. 
De acordo com Salim et al (2005, p. 56), esta seção deve ter:

- Sumário explicativo sobre o que a empresa ou unidade de negócio fará. Qual o produto ou serviço que será comercializado?

- Quem são os proprietários da empresa, seus currículos (mostrando quais são suas qualificações, mostrando sua habilitação para explorar o negócio), a forma como vão dividir suas responsabilidades na empresa e realizar seu gerenciamento.

\subsubsection{A empresa}

A Supera Produções é uma empresa que se destina a organizar eventos sociais, como formaturas, bodas, casamentos e festas de debutantes, enfatizando a criatividade e inovação na sua produção.

Objetiva proporcionar aos seus clientes a realização do seu sonho, organizando detalhadamente o evento, de forma a superar expectativas, propiciando grandes acontecimentos.

A empresa Supera Produções atuará no mercado com o foco em formaturas, ofertando seus pacotes, e criando parcerias com instituições de ensino, como universidades, faculdades e colégios de ensino médio. E, também, estará focada na organização de cerimônias, como casamentos, bodas e festas de debutantes. $\mathrm{O}$ papel da empresa é a organização e cerimonial do evento, trabalhando com empresas terceirizadas - como buffet, decoração, som e iluminação, entre outros. 


\subsubsection{Descrição da forma jurídica}

No que diz respeito à especificação da forma jurídica, é importante considerar as questões: a empresa será uma sociedade de responsabilidade limitada ou uma sociedade anônima? É preciso definir qual será seu capital, onde será sua sede, qual a sua divisão de cotas ou ações. (Salim et al, 2005, p. 59).

É relevante o conceito dos tipos de sociedades. Sobre a forma jurídica limitada, Salim et al (2005, p. 59) afirma:

A empresa necessita de um contrato social que especifique, entre outros pontos, os objetivos da empresa (áreas de atuação) e a distribuição do capital entre os sócios. Pode indicar também as suas funções diretivas e a delegação de poderes que o conjunto dos sócios atribui a cada um deles. Seu registro é feito no Registro Civil das pessoas Jurídicas, e ela está desobrigada de publicar balanços e demais demonstrações financeiras.

O mesmo autor, sobre a forma jurídica "sociedade anônima", observa:

A empresa necessita de um estatuto no qual, além de especificação dos objetivos da empresa e o relacionamento entre os acionistas, são instituídas a diretoria e o Conselho de Administração. Ela é regida pela Lei oㅡ 6.404 de 15/12/1976 e está obrigada a publicar em jornais de grande circulação os balanços e demais demonstrações financeiras. O seu registro é feito obrigatoriamente na Junta Comercial. (Salim et al, 2005, p. 59)

A empresa Supera Produções será cadastrada sob forma legal de sociedade limitada, sendo ela constituída por 2 sócios: Kellen Felizari, que será detentora de $70 \%$ da empresa, assumindo a presidência e direção geral do negócio, e Giovanny Noceti, que terá $30 \%$ da mesma, assumindo a vice-presidência e direção colaborativa do negócio.

Devido ao período de estruturação do negócio, e a necessidade de estudos ainda mais avançados, bem como o levantamento do complemento ao capital inicial - estimado em $\mathrm{R} \$ 30.000,00$-, a abertura da Supera Produções está prevista para o primeiro semestre de 2008. 


\subsubsection{Currículos dos proprietários}

Kellen Felizari, sócia majoritária, é turismóloga, e especialista em gestão de negócios em turismo pela Universidade de Brasília.

Giovanny Noceti, sócio, é historiador e mestre pela Universidade Federal de Santa Catarina, realizando atualmente funções de pesquisador e professor em faculdades.

É importante ressaltar que o conhecimento que os sócios têm desse ramo de atividade é apenas teórico, pois ainda não tiveram contato prático considerável. Por isso há a necessidade de maior aprofundamento na área, por meios de cursos práticos de organização de eventos e cerimonial.

\subsubsection{Sumário startup}

"Uma empresa startup é aquela que está sendo formada a partir da visão de um grupo de empreendedores, que se juntaram para concretizá-la." É uma empresa que ainda não existe e "o principal instrumento utilizado para tornar a startup uma realidade é o seu Plano de Negócios”. (Salim et al 2005, p. 14).

Assim, o sumário startup identifica e projeta o tempo para determinadas tarefas de implantação da empresa a ser criada.

O processo de análise do projeto e implantação da Supera Produções foi planejado em 4 etapas, seguindo o cronograma identificado no quadro abaixo, a partir de janeiro de 2008: 
Quadro 5 - Sumário Start up

\begin{tabular}{|l|l|l|}
\hline Etapas & Ações & Projeção de tempo \\
\hline 1 & Revisão do Plano de Negócio & 25 dias \\
\hline 2 & $\begin{array}{l}\text { Início e finalização das obras da sala; } \\
\text { Inicio e finalização do processo de abertura da firma; } \\
\text { Desenvolvimento do site e material de divulgação. }\end{array}$ & 75 dias \\
\hline 3 & $\begin{array}{l}\text { Compra e instalação de equipamentos (computadores, } \\
\text { mesa, cadeiras...) e material inicial; } \\
\text { Contratação de funcionários; } \\
\text { Início de divulgação e busca por parcerias. }\end{array}$ & 60 dias \\
\hline 4 & Início das operações & 20 dias \\
\hline
\end{tabular}

\subsubsection{Localização da empresa}

A empresa Supera Produções foi estudada e planejada para sua instalação na rua João Cândido Câmara, $n^{\circ} 464$, sala $6,2^{\circ}$ anda r, no centro da cidade de Dourados, Mato Grosso do Sul, por ser cidade universitária, e ter um grande número de formandos a cada semestre.

A área total da sala, localizada no segundo andar de um prédio comercial no centro da cidade, está estimada em $32 \mathrm{~m}^{2}$, comportando, portanto, toda a estrutura básica necessária ao funcionamento da empresa.

A escolha da sala foi devida à facilidade e isenção de aluguel por ser propriedade de um dos sócios, minimizando, assim, os custos fixos. 


\subsection{PRODUTOS E SERVIÇOS}

Um dos aspectos mais importante da gerência de um negócio é dar ao mercado razões para comprar seus produtos - e uma das melhores é constituída pelos benefícios que você oferece para atender aos desejos dos consumidores. (Bangs, 1999, p.36)

Para melhor definição dos produtos e serviços que serão oferecidos pela empresa, segundo Bangs (1999, p.36), se faz necessário o seguinte questionamento:

1) O que você está vendendo?

2) Quais são os benefícios (em contraposição às características) do que você está vendendo?

3) De que maneira seus produtos e/ou serviços diferem dos da concorrência?

4) Se seu produto é novo, atualizado ou de alguma forma digno de nota, o que o torna diferente? Desejável?

5) Se sua linha de produto ou serviço não é especial, por que as pessoas comprariam de você? Comodidade? Uma linha ampla de produtos? Conhecimento especializado de como utilizar os produtos que você vende?

\subsubsection{Descrição dos produtos e serviços}

A Supera Produções é uma empresa de organização de eventos e cerimonial. Portanto, terceiriza os serviços de buffet, decoração, equipamentos de multimídia, fotografia, filmagem, equipe de segurança, entre outros, deixando o cliente à vontade para escolher o parceiro que mais lhe agrada.

A Supera Produções vende sonhos, sonhos que serão realizados com segurança e profissionalismo, superando expectativas. Sua particularidade é a criação de eventos diferenciados, como festas temáticas e elementos inusitados, inovando ao estimular o lúdico. 
Além de serviços modernos e valores acessíveis, um cartão promocional, pelo qual o estudante poderá adquirir, por meio de uma parceria com a papelaria $A$ Universitária - tradicional na cidade -, material escolar durante os anos de faculdade ou ensino médio, acumulando pontos que poderão ser trocados por descontos no fechamento do pacote de formatura pela Supera Produções.

É válido observar que os 3 pacotes aqui desenvolvidos se apresentam como modelos para futuros pacotes variando em serviços e valores.

A formação desses pacotes foi estudada e planejada de acordo com os valores e estimativas reais da cidade de Dourados, e, baseando-se na média dos custos fornecidos, chegou-se aos resultados que se seguem.

Todos os pacotes aqui citados incluem serviços de som e iluminação, banda ou $D J$, segurança, buffet, bebidas, decoração, aluguel do local, entre outros. Um detalhamento maior dos serviços encontra-se nas tabelas 1, 2 e 3.

a) Pacote de formatura:

O valor foi estimado para uma turma de 35 alunos, com 19 convidados por aluno, podendo ser parcelado em até 12 vezes, ou pago à vista, com desconto de $8 \%$. A forma de pagamento (boleto, cheque, ou depósito em conta bancária) será definida pela comissão de formatura em consenso com a turma.

- $\quad$ Plano 1 = convite + aula da saudade + culto + colação

Valor total para cada formando: $\mathrm{R} \$ 404,86$

Valor à vista, com desconto de $5 \%: \mathrm{R} \$ 384,61$

Valor a prazo: 2 parcelas de $\mathrm{R} \$ 202,43$

- $\quad$ Plano 2 = convite + aula da saudade + culto + colação + baile

Valor total para cada formando: $\mathrm{R} \$ 1.961,00$

Valor à vista, com desconto de $8 \%: \mathrm{R} \$ 1.804,12$

Valor a prazo: 12 parcelas de $\mathrm{R} \$ 163,42$ 
b) Pacote de casamento e/ou bodas:

Esse pacote de casamento não inclui despesas com os noivos, como vestuário, cabelo e maquiagem, o que não impede a empresa de incluir e personalizar o pacote de acordo com a vontade do cliente.

O pacote foi elaborado com projeção para 300 pessoas.

Valor total: $\mathrm{R} \$ 26.645,75$

Valor à vista, com desconto de 5\%: $\mathrm{R} \$ 25.313,46$

Valor a prazo: 4 parcelas de $\mathrm{R} \$ 6.661,44$

c) Pacote de Festa de debutante:

O pacote da festa de debutante, também elaborado para 300 pessoas, não inclui serviços de vestuário, cabelo e maquiagem. Os valores são:

Valor total: $\mathrm{R} \$ 25.305,75$

Valor à vista, com desconto de 5\%: $\mathrm{R} \$ 24.040,46$

Valor a prazo: 4 parcelas de $\mathrm{R} \$ 6.326,44$

Os serviços de fotografia e filmagem, para esses dois últimos pacotes, incluem:

- 1 álbum com 50 fotos $24 \times 30$

- 1 DVD da filmagem, editado e personalizado

\subsubsection{Serviços terceirizados}

Estão descritos, a seguir, alguns serviços que a Supera Produções pretende contratar na organização e execução de seus eventos.

a) Locais para eventos: 
Quadro 6 - Locais para eventos, seguidos de suas características e valores

\begin{tabular}{|c|c|c|}
\hline Local & Características & Valores \\
\hline $\begin{array}{l}\text { Clube Indaiá: Salão menor } \\
\text { (390 pessoas sentadas/ } \\
\text { total de pessoas 600) }\end{array}$ & $\begin{array}{l}\text { - ar condicionado } \\
\text { - espaço para palco e buffet } \\
\text { - amplo estacionamento } \\
\text {-disponibilidade de } 165 \text { mesas e } 660 \text { cadeiras } \\
\text { - banheiro feminino e masculino }\end{array}$ & $1.225,00$ \\
\hline $\begin{array}{l}\text { Clube Indaiá: Salão maior } \\
\text { (1.500 pessoas sentadas/ } \\
\text { total de pessoas } 2.500)\end{array}$ & $\begin{array}{l}\text { - sem ar condicionado } \\
\text { - espaço para palco e buffet } \\
\text { - amplo estacionamento } \\
\text {-disponibilidade de } 165 \text { mesas e } 660 \text { cadeiras } \\
\text { - banheiro feminino e masculino }\end{array}$ & $\begin{array}{l}3.500,00 \\
\text { Promocional } \\
\text { para } 2 \text { dias de } \\
\text { locação: } \\
5.845,00\end{array}$ \\
\hline $\begin{array}{l}\text { Salão AABB - Associação } \\
\text { Atlética Banco do Brasil } \\
\text { (2.000 pessoas total) }\end{array}$ & $\begin{array}{l}\text { - sem ar condicionado } \\
\text { - espaço para buffet e palco } \\
\text { - amplo estacionamento } \\
\text { - banheiro feminino e masculino }\end{array}$ & $3.000,00$ \\
\hline $\begin{array}{l}\text { Espaço D'aldeia } \\
\text { (2.500 pessoas total) }\end{array}$ & $\begin{array}{l}\text { - disponiblidade de } 170 \text { mesas e } 680 \text { cadeiras } \\
\text { - banheiro feminino e masculino } \\
\text { - estacionamento } \\
\text { - espaço aberto } \\
\text { - espaço de bar (buffet) e palco }\end{array}$ & $\begin{array}{l}2.500,00 \text { até } \\
\text { mil pessoas, } \\
\text { acima adicional } \\
\text { de } 1.000,00\end{array}$ \\
\hline
\end{tabular}

b) Fotografias e filmagens

Nas formaturas serão disponibilizados de dois a seis profissionais para cada evento (aula da saudade, colação de grau, culto ecumênico e baile). Devida a especificidade dos serviços de fotografia e filmagem - o número de fotos varia para cada formando -, estes serão negociados diretamente com a empresa indicada.

c) Serviços de Buffet:

Cardápio básico montado a partir de sugestões da empresa cotada:

Quadro 7 - Cardápio do serviço terceirizado de buffet

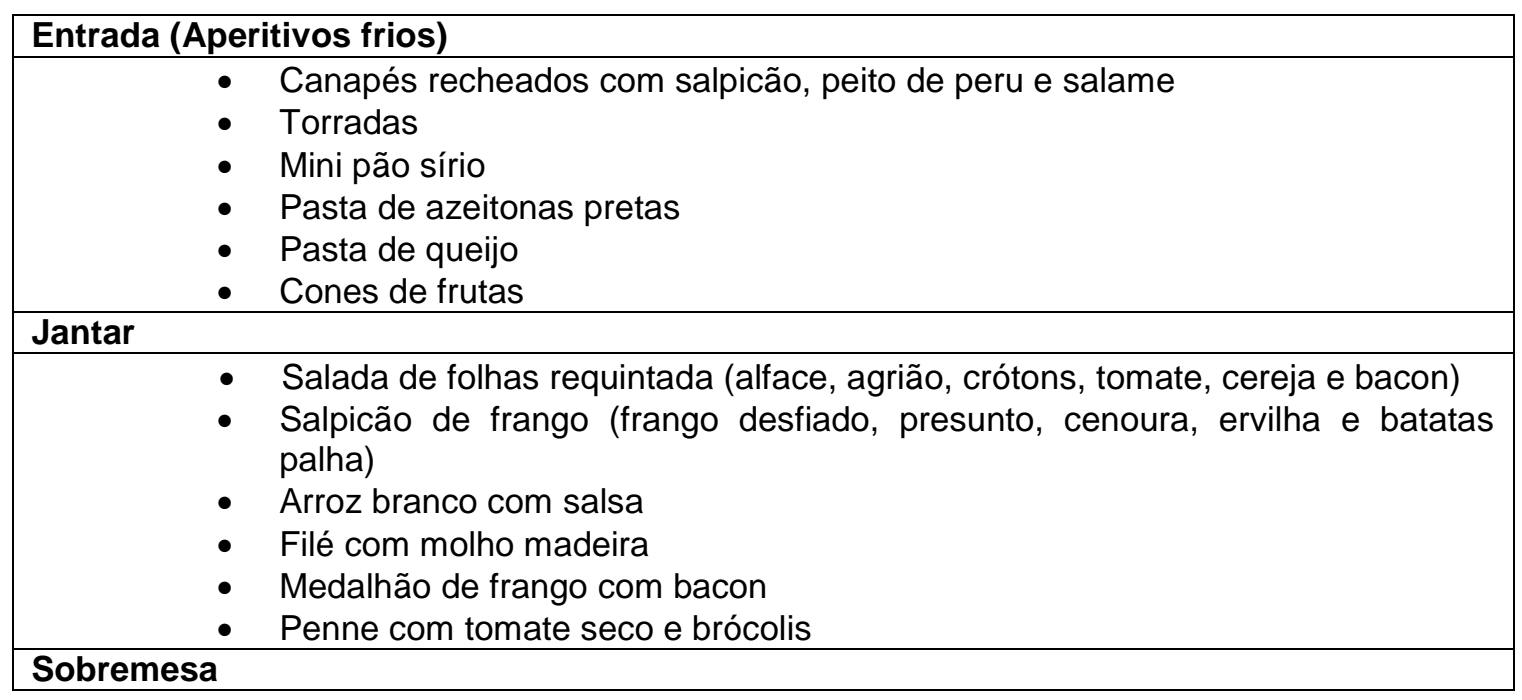




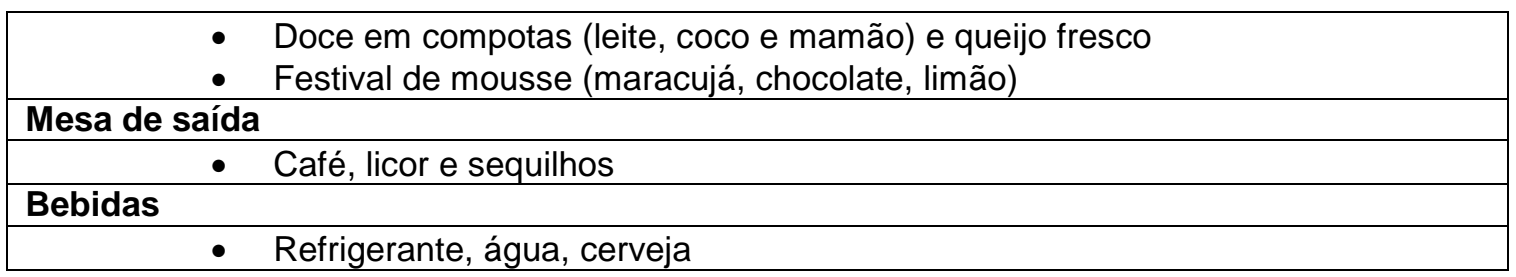

d) Decoração

A decoração, referente aos pacotes em questão, envolve os itens a seguir:

- Cerimônia de boda e/ou casamento

\section{Quadro 8 - Decoração para cerimônia de boda e/ou casamento}

\section{SERVIÇO DE DECORAÇÃO PARA IGREJA.}

- Ambientação do corredor de entrada da noiva com 10(dez) arranjos, confeccionados em colunas de ferro, madeira, ou madeira revestida com tecido adamascado. (a definir)

- 02 (dois) arranjos para o altar.

- Tapete em veludo vermelho ou verde

- Faixa lateral ao tapete.

- Genuflexório.

- Buquê para a noiva (modelo a definir).

- Buquê para a dama (caso tenha).

\section{DECORAÇÃo do SALÃo.}

- Forração total do salão.

- Ambientação do hall de entrada com 02 (dois) arranjos de grande porte, aparadores, arranjos e tapetes.

- Ambientação de espaço para mesa de bolo e bombons (junto à entrada principal), com mesas em ferro e vidro, arranjos, peças para bolo e bombons em alumínio com vidro ou de madeira, tapetes e plantas sob a mesa.

- 02 (dois) Arranjos para aparadores de jantar.

- Arranjos para mesas de frios (caso tenha).

- Arranjos para mesas de convidados em estilo a definir. (sugerimos os arranjos em dois estilos, alto e baixo).

\section{FLORES}

Para a execução do serviço proposto estaremos utilizando: rosas, flor do campo, gérberas, gladíolo, fórmio e demais complementos. 
- $\quad$ Festa de debutante

\section{Quadro 9 - Decoração para festa de debutante}

\section{DESCRICÃO DE SERVICOO DE DECORACÃO:}

- Ambientação do anti-hall de entrada com 01 (uma) tenda, devidamente forrada, com tablado, aparadores arranjos e plantas naturais.

- Forração total do salão

- Ambientação do hall de entrada com 02 (dois) arranjos de grande porte, aparadores, arranjos e tapetes

- Ambientação de espaço para mesa de bolo e bombons (mesas de ferro com vidro ou rústica de madeira), acabamento sob a mesa com plantas naturais; peças para bombons em alumínio e vidro ou caixas de madeira.

- Arranjos para mesas de convidados em estilo a definir. (sugerimos os arranjos em dois estilos, alto e baixo).

- Arranjos para aparadores de Jantar, confeccionados com folhagens, flores e frutas.

- Arranjos para mesas de frios.

- Ambientação de espaço para saída da debutante.

\section{FLORES}

Para a execução do serviço proposto estaremos utilizando: rosas, flor do campo, gérberas, gladíolo, fórmio e demais complementos.

\section{- $\quad$ Baile de Formatura}

A decoração cotada nessa etapa do trabalho foi para todas as fases da formatura. A descrição a seguir é apenas para o baile.

\section{Quadro 10 - Decoração do baile de formatura}

\section{DESCRICÃO DE SERVICOO DE DECORACÃO :}

- Ambientação do anti-hall de entrada com 01 (uma) tenda, devidamente forrada, com tablado, aparadores arranjos e plantas naturais.

- Forração total do salão

- Ambientação do hall de entrada com 02 (dois) arranjos de grande porte, aparadores, arranjos e tapetes

- Ambientação de espaço para mesa de buffet (mesas de ferro com vidro ou rústica de madeira), acabamento sob a mesa com plantas naturais;

- Arranjos para mesas de convidados em estilo a definir. (sugerimos os arranjos em dois estilos, alto e baixo).

- Arranjos para mesas de frios. 


\section{FLORES}

Para a execução do serviço proposto estaremos utilizando: rosas, flor do campo, gérberas, gladíolo, fórmio e demais complementos.

A decoração dos locais que será realizada a aula da saudade, o culto e a colação, envolverá os mesmos tipos de flores do baile. Assim, as outras fases do evento serão decoradas com arranjos e forração parcial do salão.

e) Banda

A animação escolhida para o pacote de formatura é a banda local Contramão, muito prestigiada pelo público douradense. O valor é referente a 4 horas e 30 minutos de show.

A empresa também trabalhará com bandas de fora do estado, conforme desejos do cliente.

f) Serviços de DJ (som e iluminação)

Os serviços de DJ foram cotados da seguinte forma: para até mil pessoas os pacotes incluem:

\section{Quadro 11 - Serviços de DJ}

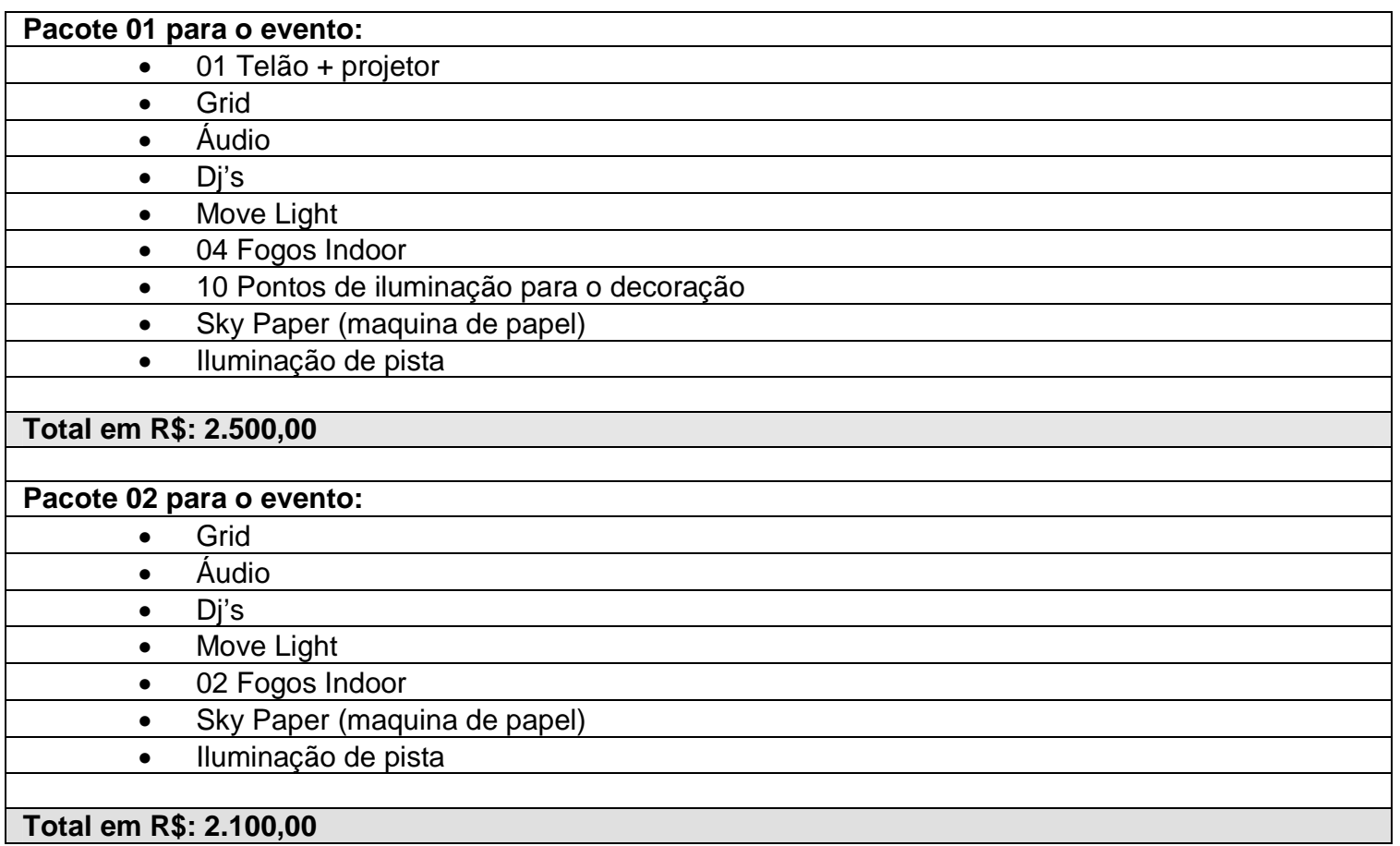


Para som, iluminação e aluguel de projetores, a empresa cotada cobra $\mathrm{R} \$ 1.000,00$ por evento até mil pessoas.

\subsection{PLANO DE MARKETING}

Para se entender a finalidade de um plano de marketing, é necessário identificar a definição do termo, que, nos dias atuais, vai além da propaganda e promoção para a venda de produtos e serviços.

Limeira (2006, p. 2) conceitua marketing como sendo a "função empresarial que cria continuamente valor para o cliente e gera vantagem competitiva duradoura para a empresa, por meio da gestão estratégica das variáveis controláveis de marketing: produto, preço, comunicação e distribuição".

American Marketing Association (AMA) apud Limeira (2006, p. 2) define marketing como "o processo de planejar e executar a concepção, precificação, promoção e distribuição de idéias, produtos e serviços”.

O Planejamento de marketing é necessário para se estabelecer os objetivos, as metas e as estratégias da empresa, estando em perfeita harmonia com o plano estratégico geral da mesma em seus objetivos e pretensões.

Sobre o desenvolvimento de planos de marketing e sua importância, Las Casas (2001, p. 21) observa que "elaborar planos de marketing contrapõe-se ao improviso, situação que pode prejudicar o andamento dos negócios". E, ainda, o mesmo autor ressalta: "no entanto, muitos sinais do ambiente podem ser detectados antecipadamente, com o hábito do planejamento, uma vez que a atividade exige sintonia com o mercado e constante adaptação." (Las Casas, 2001, p. 21).

Conforme reflexão de Limeira (2006, p. 11), quando se definem os objetivos de mercado e estratégias, o planejamento de marketing é constituído pelas seguintes etapas: 
- $\quad$ Análise de mercado;

- $\quad$ Análise da concorrência;

- Definição de cenários;

- Avaliação de riscos e oportunidades;

- $\quad$ Seleção do mercado-alvo;

- Decisão das estratégias do composto de marketing, dos investimentos e orçamentos do meio e dos meios de avaliação de resultado das ações planejadas;

Nessa etapa do plano de negócios serão determinadas as estratégias de marketing da Supera Produções, bem como a identificação das suas forças e fraquezas, suas oportunidades, ameaças e o marketing mix (produto, preço, praça e promoção).

\subsubsection{Análise de mercado}

Sobre a análise de mercado, Kotler e Bloom (1988, p. 94) observam:

Esta análise proporciona informação sobre necessidades e desejos dos clientes; é necessária para que a organização se torne reativa e orientada para marketing. A análise de mercado também fornece informações para orientar o planejamento estratégico, já que oportunidades, ameaças, pontos fortes e fracos podem ser revelados através do estudo de desejos, crenças, imagens, atitudes e níveis de satisfação dos clientes.

A análise de mercado deste plano de negócio foi desenvolvida considerando os tópicos seguintes.

\subsubsection{Segmentação do mercado}

Segundo Weinstein (1995, p. 18) apud Dias (2006, p. 18), segmentação de mercado é "o processo de dividir mercados em grupos de consumidores potenciais 
com necessidades e/ou características semelhantes e que provavelmente terão comportamentos de compra semelhantes".

De acordo com Salim et al. (2005 p. 76), os critérios de segmentação são os seguintes:

- Localização geográfica;

- Segmento econômico ou área de negócios (por exemplo, setor bancário, setor de utilidades bancárias);

- Renda familiar;

- Idade;

- Sexo;

- $\quad$ Grau de instrução;

- Profissão;

- Alguns critérios podem ser específicos para um produto/serviço.

Observa-se que a segmentação de mercado implica em identificar um grupo homogêneo, de características semelhantes, em um mercado heterogêneo, ou seja, a determinação do mercado-alvo em determinada área de atuação. Assim, a Supera Produções atuará no segmento de mercado de eventos sociais,, determinando, como seu mercado-alvo, estudantes universitários, formandos de nível médio, nubentes e debutantes.

\subsubsection{Análise da concorrência}

Foi encontrada grande dificuldade nesta etapa do trabalho, porque notou-se que as empresas do ramo, na cidade, temem a concorrência, e, como os valores desse tipo de serviço dependem de muitos fatores, não foi possível retirar-lhes certas informações. Portanto, uma saída encontrada para analisar melhor os três principais concorrentes da Supera Produções foi uma conversa informal com pessoas que utilizaram os serviços dessas empresas. Destarte, os pontos fortes e 
fracos foram definidos a partir dos relatos de quatro pessoas, as quais duas delas tiveram as formaturas organizadas pelo concorrente 1 , uma pelo concorrente 2 , e uma pelo concorrente 3 , resultando os quadros seguintes:

Quadro 12 - Análise do concorrente 1

\begin{tabular}{|l|l|}
\hline Pontos Fortes & Pontos Fracos \\
\hline - Participa gratuitamente de eventos & $\begin{array}{l}\text { - Não dispõe de meios virtuais } \\
\text { de comunicação (site) }\end{array}$ \\
\hline - Simpatia e competência profissional & - Treinamento e qualificação de funcionários \\
\hline - Parceiros e fornecedores consolidados & - Qualidades dos serviços terceirizados \\
\hline
\end{tabular}

Quadro 13 - Análise concorrente 2

\begin{tabular}{|l|l|}
\hline Pontos Fortes & Pontos Fracos \\
\hline - Flexibilidade em negociações & $\begin{array}{l}\text { - Não dispõe de meios virtuais de } \\
\text { comunicação (site) }\end{array}$ \\
\hline - Parceiros e fornecedores consolidados & $\begin{array}{l}\text { - Assumem compromissos simultâneos para } \\
\text { além da capacidade organizativa }\end{array}$ \\
\hline
\end{tabular}

Quadro14 - Análise concorrente 3

\begin{tabular}{|l|l|}
\hline Pontos Fortes & Pontos Fracos \\
\hline - Tradicional na região & $\begin{array}{l}\text { - Inflexibilidade nas negociações } \\
\text { com o cliente }\end{array}$ \\
\hline - Parceiros e fornecedores consolidados & $\begin{array}{l}\text { - preço alto não condizente a } \\
\text { qualidade dos serviços }\end{array}$ \\
\hline $\begin{array}{l}\text { - Uso de meios virtuais de comunicação } \\
\text { (e-mail e site) }\end{array}$ & - Treinamento e qualificação de funcionários \\
\hline - Contrato anual com o setor público & \\
\hline
\end{tabular}

Podemos considerar como pontos fortes da concorrência, de modo geral, o tempo de experiência de cada uma, e a quantidade de eventos realizados por eles, além de fortes parcerias.

Observa-se como ponto fraco, de modo geral, o tradicionalismo - ausência de tecnologia e meios virtuais para a divulgação e acesso personalizado aos produtos. 


\subsubsection{Análise SWOT}

Examinamos a situação de sua empresa usando uma abordagem testada conhecida como SWOT. Não se preocupe com armas ou franco-atiradores. SWOT é um acrônimo para strengths, weaknesses, opportunities, threats - pontos fortes, pontos fracos, oportunidades e ameaças. (Tiffany e Peterson, 1997, p. 144)

Entende-se, então, que a análise SWOT é desenvolvida para identificar os pontos fortes, pontos fracos, oportunidades e ameaças. Os dois primeiros são determinados considerando a visão interna da empresa, relacionada esta com os seus desejos, enquanto que, em relação às oportunidades e ameaças, levam-se em conta fatores externos, ou seja a organização em relação ao mercado.

Para melhor compreensão desses fatores, Oliveira (1997, p. 47) destaca:

Pontos fortes são vantagens estruturais controláveis pela empresa que a favorecem perante oportunidades e ameaças do ambiente.

Pontos fracos são desvantagens estruturais controláveis pela empresa que a desfavorecem perante oportunidades e ameaças do ambiente.

O mesmo autor ainda define:

Oportunidades são forças ambientais incontroláveis pela empresa que podem favorecer sua ação estratégica, desde que reconhecidas e aproveitadas satisfatoriamente enquanto perduram.

Ameaças são forças ambientais incontroláveis pela empresa que criam obstáculos e sua ação estratégica, mas que poderão ou não ser evitadas, desde que reconhecidas em tempo hábil. (Oliveira, 1997, p. 44) 


\section{Quadro 15 - Matriz SWOT}

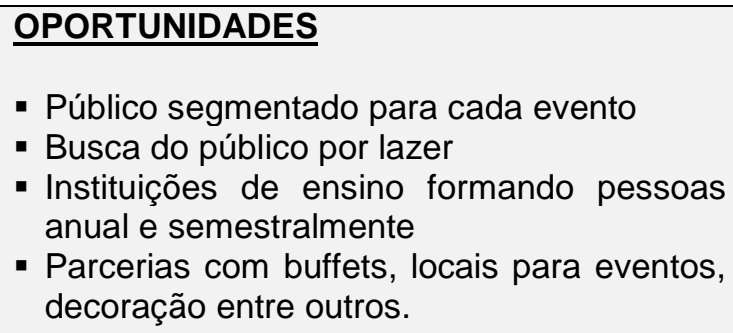

- Público segmentado para cada evento

- Busca do público por lazer

- Instituições de ensino formando pessoas anual e semestralmente

- Parcerias com buffets, locais para eventos, decoração entre outros.

\section{PONTOS FORTES}

- Competência dos organizadores

- Inovações constantes

- Serviços diferenciados

- Qualidade dos serviços

- Uso de tecnologias

\section{AMEACAS}

- Disponibilidade de espaços para a execução dos eventos

- A segmentação exige gastos altos que influenciarão no investimento do cliente

- Limitação do público por segmentação do evento

- Capacidade de improvisações devido ao tipo de negócio

\section{PONTOS FRACOS}

- Custos operacionais

- Carteira de clientes

- Dependência de fornecedores e parceiros

- Inexperiência dos proprietários

\subsubsection{Marketing Mix}

Para Salim et al (2005, p. 219):

O marketing mix compreende todas as estratégias relacionadas ao sucesso do empreendimento. Caracteriza-se pelas análises de marketing em produto (posicionamento), preço, praça (canais de distribuição) e promoção, também conhecidos como os 4 Ps.

Considerando essa definição, a Supera Produções desenvolve as seguintes estratégias envolvendo produto, preço, praça e promoção.

\subsubsection{Produto (posicionamento)}

Segundo Cobra (1995, p. 170), "o posicionamento é entendido como o lugar que o produto ocupa na mente de um consumidor em relação aos produtos 
concorrentes", sendo que este "poderá ser diferenciado dos demais concorrentes através da estratégia de posicionamento da marca do produto".

Ainda de acordo com Cobra (1995, p. 170), para se posicionar um produto é preciso considerar alguns aspectos, como:

1. Analisar quais são os principais atributos do produto que os consumidores valorizam.

2. Avaliar a distribuição desses atributos entre os diferentes segmentos de mercado.

3. Determinar a posição ótima para o produto em relação a cada atributo, confrontando o produto com as marcas existentes.

4. Escolher a posição ideal para o produto em relação às outras marcas no mercado.

A Supera Produções pretende fornecer serviços com qualidade, segurança, criatividade e inovação, atingindo o seu público-alvo ao promover eventos criativos e interessantes. Seu diferencial será, além do profissionalismo e da manutenção de um site - onde o cliente poderá obter, instantaneamente, um orçamento prévio dos serviços, verificando o andamento do projeto, e mantendo um contato mais estreito com a empresa -, o componente criativo e inovador na execução dos eventos. A Supera deseja ser lembrada por produzir eventos diferenciados e criativos, e, mais ainda, como um meio de realizar sonhos.

A palavra "Supera" foi adotada porque seu significado sugere a idéia de força, grandeza, realização, algo que exija resultados, além de ela ressaltar a missão da empresa, que é a de superar as expectativas do cliente na realização de seus eventos.

A logomarca foi elaborada sob os seguintes parâmetros, tomando-se por base o programa editor de textos Microsoft Word:

- Título: Tunga, cor preta, tamanho 48, itálico, com dois frisos na parte inferior, espaçamento entre caracteres "condensado 5 pt", sob fundo branco;

- Subtítulo: Century Gothic, cor preta, tamanho 22, espaçamento entre caracteres "condensado 1,5 pt", sob fundo branco. 
llustração 1 - Logomarca empresa

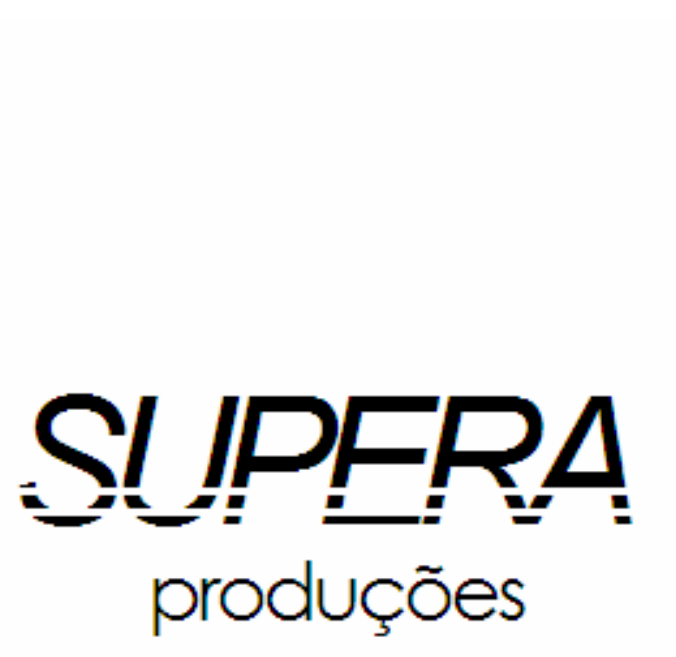

4.4.5.2 Preço

Skacel (1992, p. 55) lista alguns passos para se determinar o preço do produto ou serviço. São eles:

1. Ofereça valor pelo dinheiro gasto seja qual for o nível de qualidade.

2. Iguale-se à concorrência, vença-a ou coloque-se num nível de preço que seja mais compatível com seus alvos de volume e crescimento.

3. Ofereça descontos especiais e preços sazonais.

4. Acrescente taxas para ser mais seletivo, cobrir custos de um serviço original, embalagem ou sistema de entrega.

5. Abaixe o preço para atrair mais usuários; reduza os custos de um produto/serviço mudando seu formato ou conteúdo.

6. Ofereça incentivos, reembolsos, acessórios grátis, prêmios.

7. Ofereça preços segundo a quantidade para grandes utilizadores. 
8. Ofereça preços mais atraentes para um grupo de produtos /serviços relacionados (conhecido como "pacote") para encorajar os consumidores a usarem uma combinação mais favorável de produtos/serviços.

9. Ofereça prazos mais longos, faturamento ou descontos para pagamento antecipado.

Os valores dos eventos da Supera Produções serão determinados de acordo com os desejos do cliente, e os custos com o padrão dos fornecedores e parceiros.

Ela trabalhará para realizar o sonho do seu cliente, seja em sua formatura, boda, casamento ou festa de debutante. Os valores dos eventos estarão relacionados a qualidade e segurança, sempre priorizando a escassez de falhas, e a realização dos desejos do consumidor. Para isso, a empresa estará sempre atualizada, acompanhando as tendências do mercado nos quesitos produção, criatividade e valor.

Neste plano de negócio foram criados três pacotes básicos de eventos realizáveis pela empresa - o que não impede a elaboração de outros, pois os pacotes serão criados acordando com a exigência dos clientes.

Para melhor definição dos valores, e percepção da realidade desse mercado de eventos, conversou-se, como já citado, com profissionais e empresários do ramo em Brasília, já que as principais empresas da cidade de implantação da Supera Produções não se mostraram cordiais a esse tipo de relação, o que já era esperado.

Almejando maior credibilidade junto ao mercado de eventos, optou-se pela exclusão das comissões para cada serviço terceirizado formador do pacote. A alternativa encontrada foi a adição do item "assessoria e cerimonial" em cada pacote, como forma de discriminar o montante cobrado pelos serviços da Supera Produções. A base de cálculo para se chegar aos valores foi de $20 \%$ do total dos custos dos serviços terceirizados.

Para uma melhor visualização, a fórmula utilizada na planilha eletrônica MS Excel foi [valor total+(valor total $\left.{ }^{\star} 20 \%\right)$-valor total], e no pacote de casamento e boda, bem como o de festa de debutante, foi calculado 15\%, demonstrado na fórmula [valor total+(valor total $\left.{ }^{\star} 15 \%\right)$-valor total].

Seguem-se os pacotes desenvolvidos nesse trabalho. 
Formatura: estimado para 35 formandos e 19 convidados, totalizando cerca de 700 pessoas, sendo que para as outras etapas do evento (colação e culto ecumênico) estima-se cerca de 350 a 400.

No pacote de formatura, na colação de grau, observa-se que o item "Som e iluminação com $D S$ ', após a conclusão do cerimonial e protocolo da outorga de grau, executa uma seleção com as músicas escolhidas pela turma, e a anima durante alguns minutos o auditório, com iluminação de boate. No baile, o mestre de cerimônias é caracterizado de acordo com o tema da festa, realizando uma performance de acordo com a personagem.

Tabela 1 - Pacote de formatura

\begin{tabular}{|c|c|c|c|}
\hline Formatura & & & \\
\hline \multicolumn{4}{|l|}{ Serviços (para 35 formandos) } \\
\hline Convite & Valor de custo & Valor de venda & $\begin{array}{l}\text { Valor de venda } \\
\text { individual }\end{array}$ \\
\hline $\begin{array}{l}\text { 1. Foto do convite (grupo, sub grupo, } \\
\text { individual) }\end{array}$ & $\mathrm{R} \$ 350,00$ & $\mathrm{R} \$ 350,00$ & $\mathrm{R} \$ 10,00$ \\
\hline $\begin{array}{l}\text { 2. Confecção convite da Formatura ( } 10 \text { para } \\
\text { cada formando) }\end{array}$ & $\mathrm{R} \$ 3.500,00$ & $\mathrm{R} \$ 3.500,00$ & $\mathrm{R} \$ 100,00$ \\
\hline Total & $\mathrm{R} \$ \mathbf{3 . 8 5 0 , 0 0}$ & $\mathrm{R} \$ 3.850,00$ & R\$ 110,00 \\
\hline \multicolumn{4}{|l|}{ 2. Aula de encerramento (saudade) } \\
\hline 2.1 Assessoria e cerimonial & & $\mathrm{R} \$ 192,00$ & $\mathrm{R} \$ 5,49$ \\
\hline 2.2 Mestre de cerimônias & $\mathrm{R} \$ 150,00$ & $\mathrm{R} \$ 150,00$ & $\mathrm{R} \$ 4,29$ \\
\hline 2.3 Coordenador & $\mathrm{R} \$ 100,00$ & $\mathrm{R} \$ 100,00$ & $\mathrm{R} \$ 2,86$ \\
\hline 2.4 Recepcionistas (2) & $\mathrm{R} \$ 160,00$ & $\mathrm{R} \$ 160,00$ & $\mathrm{R} \$ 4,57$ \\
\hline 2.5 Assistente técnico & $\mathrm{R} \$ 150,00$ & $\mathrm{R} \$ 150,00$ & $\mathrm{R} \$ 4,29$ \\
\hline 2.6 Decoração & $\mathrm{R} \$ 400,00$ & $\mathrm{R} \$ 400,00$ & $\mathrm{R} \$ 11,43$ \\
\hline Total & $R \$ 960,00$ & R\$ 1.152,00 & $\mathrm{R} \$ 32,91$ \\
\hline \multicolumn{4}{|l|}{ 3. Culto ecumênico } \\
\hline 3.1 Assessoria e cerimonial & & $\mathrm{R} \$ 559,00$ & $\mathrm{R} \$ 15,97$ \\
\hline 3.2 Mestre de cerimônias & $\mathrm{R} \$ 150,00$ & $\mathrm{R} \$ 150,00$ & $\mathrm{R} \$ 4,29$ \\
\hline 3.3 Coordenador & $\mathrm{R} \$ 100,00$ & $\mathrm{R} \$ 100,00$ & $\mathrm{R} \$ 2,86$ \\
\hline 3.4 Recepcionistas (4) & $\mathrm{R} \$ 320,00$ & $\mathrm{R} \$ 320,00$ & $\mathrm{R} \$ 9,14$ \\
\hline 3.5 Decoração & $\mathrm{R} \$ 1.000,00$ & $\mathrm{R} \$ 1.000,00$ & $\mathrm{R} \$ 28,57$ \\
\hline 3.6 Aluguel local & $\mathrm{R} \$ 1.225,00$ & $\mathrm{R} \$ 1.225,00$ & $\mathrm{R} \$ 35,00$ \\
\hline Total & R\$ 2.795,00 & R\$ 3.354,00 & R\$ 95,83 \\
\hline \multicolumn{4}{|l|}{ 4. Colação de grau } \\
\hline 4.1 Assessoria e cerimonial & & $\mathrm{R} \$ 969,00$ & $\mathrm{R} \$ 27,69$ \\
\hline 4.2 Mestre de cerimônias & $\mathrm{R} \$ 150,00$ & $\mathrm{R} \$ 150,00$ & $\mathrm{R} \$ 4,29$ \\
\hline
\end{tabular}




\begin{tabular}{|c|c|c|c|}
\hline 4.3 Recepcionistas (4) & $\mathrm{R} \$ 320,00$ & $\mathrm{R} \$ 320,00$ & $\mathrm{R} \$ 9,14$ \\
\hline 4.4 Assistente técnico & $\mathrm{R} \$ 100,00$ & $\mathrm{R} \$ 100,00$ & $\mathrm{R} \$ 2,86$ \\
\hline 4.5 Decoração & $\mathrm{R} \$ 2.000,00$ & $\mathrm{R} \$ 2.000,00$ & $\mathrm{R} \$ 57,14$ \\
\hline 4.6 Becas & $\mathrm{R} \$ 700,00$ & $\mathrm{R} \$ 700,00$ & $\mathrm{R} \$ 20,00$ \\
\hline 4.7 Canudos & $\mathrm{R} \$ 175,00$ & $\mathrm{R} \$ 175,00$ & $\mathrm{R} \$ 5,00$ \\
\hline 4.8 Serviços de água para mesa & $\mathrm{R} \$ 100,00$ & $\mathrm{R} \$ 100,00$ & $\mathrm{R} \$ 2,86$ \\
\hline 4.9 Som e iluminação com DJ & $\mathrm{R} \$ 1.000,00$ & $\mathrm{R} \$ 1.000,00$ & $\mathrm{R} \$ 28,57$ \\
\hline \multicolumn{4}{|l|}{ 4.10 Aluguel local (cedido pela universidade) } \\
\hline 4.11 Placas de homenagens (6) & $\mathrm{R} \$ 300,00$ & $\mathrm{R} \$ 300,00$ & $\mathrm{R} \$ 8,57$ \\
\hline Total & $\mathrm{R} \$ 4.845,00$ & $\mathrm{R} \$ 5.814,00$ & R\$ 166,11 \\
\hline $\begin{array}{l}\text { Plano 1: Aula da Saudade + Culto + } \\
\text { Colação de Grau + convite }\end{array}$ & $R \$ 12.450,00$ & $\mathrm{R} \$ 14.170,00$ & $\mathrm{R} \$ 404,86$ \\
\hline A prazo: Divide em $2 X s$ iguais de & $\mathrm{R} \$ 6.225,00$ & $\mathrm{R} \$ 7.085,00$ & $\mathrm{R} \$ 202,43$ \\
\hline A vista: Desc de $5 \%$ & $\mathrm{R} \$ 11.827,50$ & $\mathrm{R} \$ 13.461,50$ & $\mathrm{R} \$ 384,61$ \\
\hline \multicolumn{4}{|l|}{ 5. Baile de Formatura } \\
\hline 5.1 Assessoria e cerimonial & & $\mathrm{R} \$ 9.077,50$ & $\mathrm{R} \$ 259,36$ \\
\hline 5.2 Mestre de cerimônias & $\mathrm{R} \$ 150,00$ & $\mathrm{R} \$ 150,00$ & $\mathrm{R} \$ 4,29$ \\
\hline 5.4 Recepcionistas (6) & $\mathrm{R} \$ 480,00$ & $\mathrm{R} \$ 480,00$ & $\mathrm{R} \$ 13,71$ \\
\hline 5.5 Assistente técnico & $\mathrm{R} \$ 100,00$ & $\mathrm{R} \$ 100,00$ & $\mathrm{R} \$ 2,86$ \\
\hline 5.6 Seguranças (25) & $\mathrm{R} \$ 1.750,00$ & $\mathrm{R} \$ 1.750,00$ & $\mathrm{R} \$ 50,00$ \\
\hline 5.7 Decoração & $\mathrm{R} \$ 4.000,00$ & $\mathrm{R} \$ 4.000,00$ & $\mathrm{R} \$ 114,29$ \\
\hline 5.8 Som e iluminação (com telão e projetor) & $\mathrm{R} \$ 2.500,00$ & $\mathrm{R} \$ 2.500,00$ & $\mathrm{R} \$ 71,43$ \\
\hline 5.9 Aluguel do salão & $\mathrm{R} \$ 2.930,00$ & $\mathrm{R} \$ 2.930,00$ & $\mathrm{R} \$ 83,71$ \\
\hline 5.10 Serviços de garçons (20) & $\mathrm{R} \$ 2.000,00$ & $\mathrm{R} \$ 2.000,00$ & $\mathrm{R} \$ 57,14$ \\
\hline $\begin{array}{l}\text { 5.11 Coquetel e café da manhã (formandos e } \\
\text { convidados) }\end{array}$ & $\mathrm{R} \$ 17.500,00$ & $\mathrm{R} \$ 17.500,00$ & $\mathrm{R} \$ 500,00$ \\
\hline $\begin{array}{l}5.12 \text { Bebidas }-2 \text { tipos de refrigerante ( } 175 \\
\text { gar. 2l.), água ( } 800 \text { gar. } 500 \mathrm{ml} \text { ) cerveja } \\
\text { ( } 2.800 \text { gar.) }\end{array}$ & $\mathrm{R} \$ 9.477,50$ & $\mathrm{R} \$ 9.477,50$ & $\mathrm{R} \$ 270,79$ \\
\hline 5.13 Banda & $\mathrm{R} \$ 4.500,00$ & $\mathrm{R} \$ 4.500,00$ & $\mathrm{R} \$ 128,57$ \\
\hline Total & $\mathrm{R} \$ \mathbf{4 5 . 3 8 7 , 5 0}$ & $\mathrm{R} \$ 54.467,00$ & $\mathrm{R} \$ 1.556,14$ \\
\hline $\begin{array}{l}\text { Plano 2: Aula + Culto + Colação + Baile de } \\
\text { Formatura + convite }\end{array}$ & $\mathrm{R} \$ \mathbf{5 7 . 8 3 7 , 5 0}$ & $\mathrm{R} \$ \mathbf{6 8 . 6 3 7 , 0 0}$ & $\mathrm{R} \$ 1.961,00$ \\
\hline A prazo: Divide em 12Xs iguais de & $\mathrm{R} \$ \mathbf{4 . 8 1 9 , 7 9}$ & $\mathrm{R} \$ 5.719,75$ & $R \$ 163,42$ \\
\hline A vista: Desc de $8 \%$ & $\mathrm{R} \$ \mathbf{5 3 . 2 1 0 , 5 0}$ & $\mathrm{R} \$ \mathbf{6 3 . 1 4 6 , 0 4}$ & $\mathrm{R} \$ 1.804,12$ \\
\hline
\end{tabular}

Esse pacote está dividido em:

- Valor de custo - que é o valor dos serviços dos fornecedores da cidade de Dourados;

- Valor de venda - valor total de custo já com a comissão para apresentação ao cliente; 
- Valor de venda individual - é o valor de venda para cada aluno.

De acordo com as formas de pagamento de mercado, os pacotes de formatura serão vendidos à vista, com desconto de $8 \%$, ou divididos em até 12 vezes. Em todos os pacotes de formatura da Supera Produções haverá a opção de compra dos planos descritos no quadro.

Os valores dos serviços de filmagem e fotografia, bem como a confecção do álbum e fotos adicionais, serão negociados pelos clientes diretamente com os fornecedores, pois, de acordo com a empresa prestadora desse tipo de serviço, haverá um contrato onde o cliente se responsabilizará pela compra de $80 \%$ do material desenvolvido.

O valor da filmagem e fotografia constado no pacote inclui, além dos serviços:

- 1 álbum com 50 fotos $24 \times 30$

- 1 DVD da filmagem personalizado

Os pacotes a seguir são temáticos. O casamento apresenta-se com características havaianas, e a festa de debutantes, de baile de máscaras. Eles são desenvolvidos para 300 pessoas, incluindo o valor de custo e o valor de venda.

Tabela 2 - Pacote de casamento/boda

\begin{tabular}{l|l|l}
\hline Casamento e bodas (300 pessoas) & Valor de custo & \\
\hline 1. Assessoria e cerimonial & & $\mathrm{R} \$ 3.450,75$ \\
\hline 2. Coordenadores (2) & $\mathrm{R} \$ 200,00$ & $\mathrm{R} \$ 200,00$ \\
\hline 3. Seguranças (10) & $\mathrm{R} \$ 700,00$ & $\mathrm{R} \$ 700,00$ \\
\hline 4. Decoração (igreja e salão) & $\mathrm{R} \$ 5.000,00$ & $\mathrm{R} \$ 5.000,00$ \\
\hline 5. Som com DJ e iluminação (com telão e projetor) & $\mathrm{R} \$ 2.500,00$ & $\mathrm{R} \$ 2.500,00$ \\
\hline 6. Aluguel do salão & $\mathrm{R} \$ 1.225,00$ & $\mathrm{R} \$ 1.225,00$ \\
\hline 7. Buffet (25,00 por pessoa) & $\mathrm{R} \$ 7.500,00$ & $\mathrm{R} \$ 7.500,00$ \\
\hline 8. Serviços garçons (10) & $\mathrm{R} \$ 900,00$ & $\mathrm{R} \$ 900,00$ \\
\hline 9. Bebidas (Água, 2 tipos de refrigerante, cerveja) & $\mathrm{R} \$ 3.060,00$ & $\mathrm{R} \$ 3.060,00$ \\
\hline 9. Filmagem (1 câmera) e fotografia (1 câmera) & $\mathrm{R} \$ 1.200,00$ & $\mathrm{R} \$ 1.200,00$ \\
\hline 10. Convite com envelope (300) & $\mathrm{R} \$ 720,00$ & $\mathrm{R} \$ 720,00$ \\
\hline 11. Taxa igreja & $\mathrm{R} \$ 190,00$ & $\mathrm{R} \$ 190,00$ \\
\hline Total & $\mathbf{R} \mathbf{2 3 . 0 0 5 , 0 0}$ & $\mathbf{R} \mathbf{2 6 . 6 4 5 , 7 5}$ \\
\hline A prazo: Divide em 4Xs iguais de & $\mathbf{R} \mathbf{5 . 7 5 1 , 2 5}$ & $\mathbf{R} \mathbf{6 . 6 6 1 , 4 4}$ \\
\hline A vista: Desc de 5\% & $\mathbf{R} \mathbf{2 1 . 8 5 4 , 7 5}$ & $\mathbf{R} \mathbf{2 5 . 3 1 3 , 4 6}$ \\
\hline
\end{tabular}


Tabela 3 - Pacote de festa de debutante

\begin{tabular}{l|l|l}
\hline Festa de debutante (300 pessoas) & Valor de Custo & $\begin{array}{l}\text { Valor de } \\
\text { venda }\end{array}$ \\
\hline 1. Assessoria e cerimonial & & $\mathrm{R} \$ 3.300,75$ \\
\hline 2. Coordenadores (2) & $\mathrm{R} \$ 200,00$ & $\mathrm{R} \$ 200,00$ \\
\hline 3. Seguranças (10) & $\mathrm{R} \$ 700,00$ & $\mathrm{R} \$ 700,00$ \\
\hline 4. Decoração & $\mathrm{R} \$ 4.000,00$ & $\mathrm{R} \$ 4.000,00$ \\
\hline 5. Som com DJ e iluminação (com telão e projetor) & $\mathrm{R} \$ 2.500,00$ & $\mathrm{R} \$ 2.500,00$ \\
\hline 6. Aluguel do salão & $\mathrm{R} \$ 1.225,00$ & $\mathrm{R} \$ 1.225,00$ \\
\hline 7. Equipe Buffet (25,00 por pessoa) & $\mathrm{R} \$ 7.500,00$ & $\mathrm{R} \$ 7.500,00$ \\
\hline 8. Serviços garçons (10) & $\mathrm{R} \$ 900,00$ & $\mathrm{R} \$ 900,00$ \\
\hline 9. Bebidas (Água, 2 tipos de refrigerante, cerveja) & $\mathrm{R} \$ 3.060,00$ & $\mathrm{R} \$ 3.060,00$ \\
\hline 9. Filmagem (1 câmera) e fotografia (1 câmera) & $\mathrm{R} \$ 1.200,00$ & $\mathrm{R} \$ 1.200,00$ \\
\hline 10. Convite com envelope (300) & $\mathrm{R} \$ 720,00$ & $\mathrm{R} \$ \mathbf{7 2 0 , 0 0}$ \\
\hline Total & $\mathbf{R} \mathbf{2 2 . 0 0 5 , 0 0}$ & $\mathbf{R} \mathbf{2 5 . 3 0 5 , 7 5}$ \\
\hline A prazo: Divide em $\mathbf{4 X s ~ i g u a i s ~ d e ~}$ & $\mathbf{R} \mathbf{5 . 5 0 1 , 2 5}$ & $\mathbf{R} \mathbf{6 . 3 2 6 , 4 4}$ \\
\hline A vista: Desc de $\mathbf{5} \%$ & $\mathbf{R} \mathbf{2 0 . 9 0 4 , 7 5}$ & $\mathbf{R} \mathbf{2 4 . 0 4 0 , 4 6}$ \\
\hline
\end{tabular}

\subsubsection{Praça}

Em inglês, placement significa praça, ponto ou distribuição. "Trata-se de toda a estrutura de canais de distribuição e logística que viabilizam a entrega ou aquisição do produto ao cliente". Azevedo (2002, p. 16).

A Supera Produções estará situada no centro da cidade de Dourados, no Mato Grosso do Sul. Como será um empreendimento que não precisará de grandes instalações, o escritório estará localizado no segundo andar do prédio da papelaria $A$ Universitária, as quais trabalharão em conjunto, no uso do cartão promocional para os estudantes.

O funcionamento das atividades no escritório será em horário comercial, de segunda a sexta, tendo plantão de 24 horas em dias de eventos.

A empresa pretende, futuramente, expandir seu atendimento para as cidades vizinhas, onde se percebe uma considerável demanda, e diminuta oferta desse tipo de serviço. Essa distribuição será feita por um funcionário do quadro fixo da empresa, com condução própria. 


\subsubsection{Promoção}

"É o esforço da empresa em comunicar a existência de seus produtos (ou serviços) ao mercado e promovê-los, utilizando os meios de comunicação" (Azevedo, 2002, p. 16).

A Supera Produções usará os seguintes meios para se promover:

Cartão fidelidade: disponibilizar-se-á para os estudantes universitários e do ensino médio, no ato do fechamento do pacote de formatura, um cartão promocional em parceria com a papelaria mais tradicional da cidade, onde a cada compra serão acumulados pontos, que o estudante poderá trocar por brindes.

Internet: a empresa terá um portal bem elaborado na internet, com acesso de forma fácil e rápida, e que será constituído, basicamente, por informações sobre a empresa, eventos realizados, eventos a realizar, promoções, contato, além de um espaço especifico para o cliente acompanhar todo o andamento de seu evento e sugestões.

Outdoors: inicialmente serão distribuídos alguns out doors pela cidade, em pontos estratégicos como nas proximidades de universidades, colégios e no centro urbano.

Rede de televisão: a empresa utilizará o programa de TV da cidade para se apresentar e divulgar seus serviços.

Folders e panfletos explicativos: de início serão distribuídos folders e panfletos explicativos, apresentando da empresa em colégios e outras instituições de ensino. Também será realizada mala direta com material diferenciado, visando futuras parcerias e captação de clientes - isso a partir o departamento responsável em instituições de ensino.

Responsabilidade social: A Supera Produções contratará funcionários e parceiros regionais, gerando emprego para a comunidade, e movimentando a economia local, comprometendo-se também com projetos sociais da região. 
Responsabilidade ambiental: A empresa manterá a segurança no trabalho, resguardando a saúde do trabalhador, e adotará métodos que minimizem as agressões ao meio ambiente, como uso de papel e produtos reciclados.

\subsection{PLANO OPERACIONAL}

Nessa etapa do plano, de acordo com Pereira e Santos (1995, p. 171), "o empreendedor deve estudar e decidir sobre os aspectos técnicos do empreendimento".

Observa-se, dessa forma, que o plano operacional trata da estrutura interna e externa da empresa, relacionando-se, aqui, itens físicos indispensáveis para a abertura e funcionamento do empreendimento.

\subsubsection{Estrutura física}

Os itens básicos relacionados a seguir completam a estrutura física básica da empresa Supera Produções.

Quadro 16 - Estrutura física da empresa

\begin{tabular}{|ll|}
\hline Mobília & Quantidade \\
\hline Computadores & 4 \\
Aparelho multifuncional (impressora, fax, xerox) & 1 \\
Aparelho telefônico & 2 \\
Mesa de trabalho & 2 \\
Mesa para reunião & 1 \\
Cadeira para a mesa de reunião & 6 \\
Cadeira de escritório & 6
\end{tabular}




\begin{tabular}{|ll|} 
Armário/ arquivo & 1 \\
\hline Objetos & Quantidade \\
\hline Lixeiras & 3 \\
Filtro de água & 1 \\
\hline
\end{tabular}

\subsubsection{Disposição interna}

A sala menor com $14 \mathrm{~m}^{2}$ apresenta-se como a recepção contendo 2 computadores, um aparelho telefônico e uma impressora multifuncional com fax, xerox e scanner. A segunda sala medindo $18 \mathrm{~m}^{2}$ é a sala da gerência com 2 computadores, uma mesa para reuniões, um armário/ arquivo, para depósito de materiais diversificados e arquivo de projetos antigos e a serem realizados.

Ilustração 2 - Layout da empresa

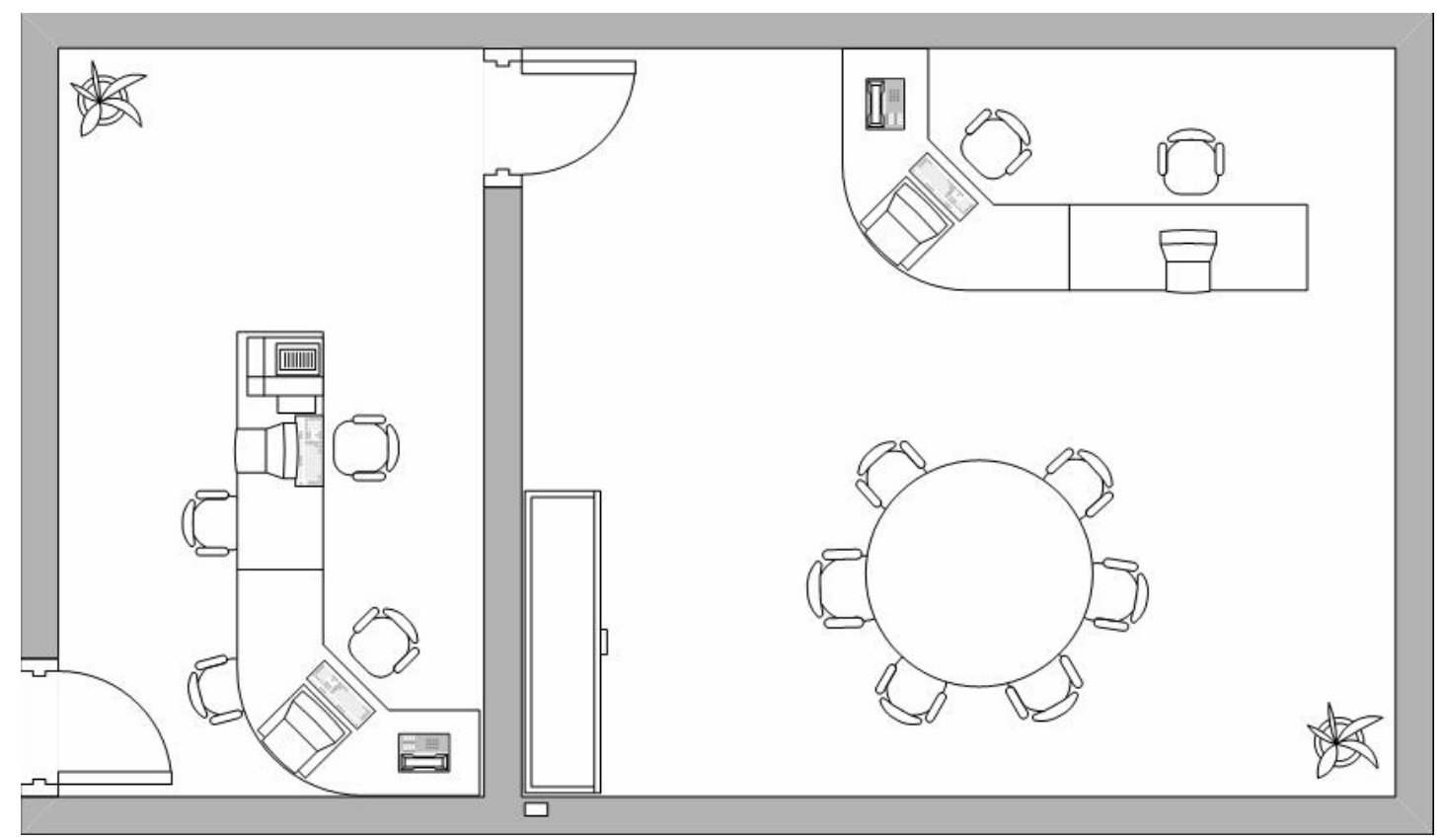




\subsubsection{Estrutura organizacional}

A gerência da empresa será composta pelos dois sócios. Um deles será responsável pela gerência comercial, envolvendo as vendas e estratégias de marketing, enquanto o outro responsabilizar-se-á pela gerência administrativa (funcionários e serviços relacionados), e pela gerência financeira, envolvendo entrada e saída de receita.

A empresa terá interesse em contratar estagiários para seu quadro fixo de pessoal no primeiro ano, fornecendo oportunidades de aprendizado ao estudante, e minimizando os custos da organização com funcionários e encargos.

Já no ano dois, a Supera Produções contratará um profissional formado, ou cursando Administração, para exercer a função de auxiliar administrativo, trabalhando diretamente com o gerente administrativo, e um promotor de vendas com condução própria e experiência, para fechar negócio com parceiros e clientes.

A sede da empresa contará também um funcionário disponível em horário comercial, exercendo tarefas de secretaria - atendimento ao cliente, telefonemas, cadastros, entre outros.

Como a sala comercial projetada para a sede da empresa não dispõe de banheiro privado, a contratação de faxineira é dispensável inicialmente. Cada funcionário poderá organizar e limpar sua mesa enquanto que a limpeza do chão poderá ser feita pela secretária, ou um outro funcionário, e, até mesmo, os gerentes.

\subsubsection{Organograma}

A Supera Produções terá um quadro de colaboradores formado pelos dois sócios e por dois estagiários em seu primeiro ano de vida, os quais ocuparão o cargo de secretário e auxiliar administrativo. 
Organograma 1 - Hierarquia da empresa relativa ao ano 1:

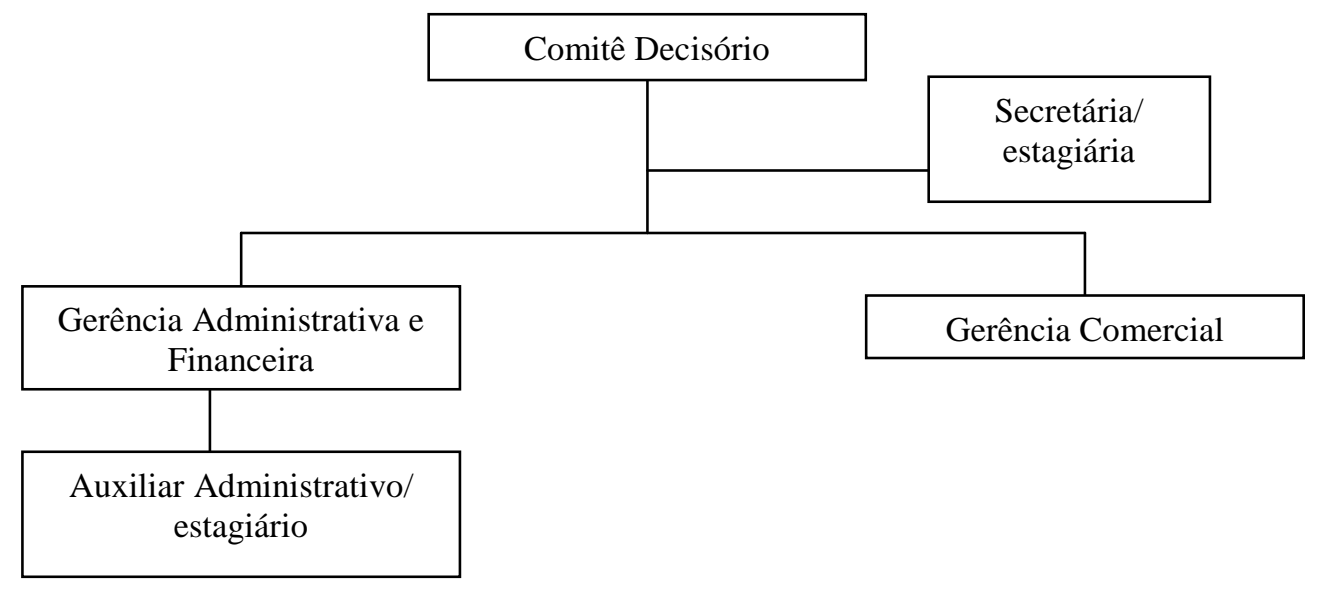

Segue-se o organograma do ano 2, inclusos os funcionários efetivos:

Organograma 2 - Hierarquia da empresa relativa ao ano 2

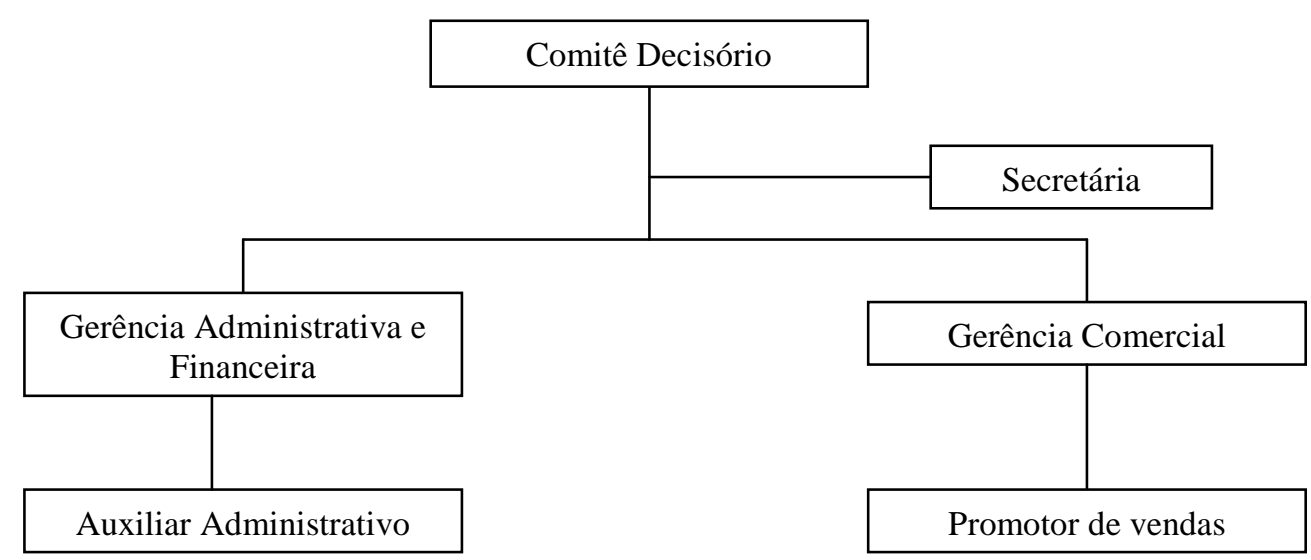




\subsubsection{Treinamento}

Todos os funcionários e estagiários da empresa serão treinados e atualizados para atender com excelência. Os funcionários terceirizados do cerimonial também receberão treinamento compatível a cada evento.

O treinamento será composto por palestras e cursos na área de atuação de cada um, sendo os colaboradores sempre informados sobre as mudanças internas, como quadro de pessoal, valores, promoções, e outros assuntos.

\subsubsection{Cargos e responsabilidades}

Os cargos e responsabilidades serão divididos da seguinte forma no ano inicial da empresa:

Quadro 17 - Cargos e funções dos funcionários para o ano 1

\begin{tabular}{|l|l|}
\hline Cargo & Função \\
\hline Gerente administrativo e financeiro & $\begin{array}{l}\text { Responsável pelos serviços } \\
\text { administrativos junto ao escritório contábil, } \\
\text { pelo planejamento financeiro e } \\
\text { contratação de pessoal. }\end{array}$ \\
\hline Gerente comercial & $\begin{array}{l}\text { Responsável pelo marketing, negociação } \\
\text { e departamento de vendas. Nos eventos, } \\
\text { realizará também a função de } \\
\text { coordenador de cerimonial. }\end{array}$ \\
\hline Estagiário (Auxiliar administrativo) & \begin{tabular}{l} 
Serviços administrativos auxiliares \\
\hline Estagiária (Secretária)
\end{tabular} \\
\hline
\end{tabular}


Os serviços de divulgação da empresa na cidade e região, bem como a concretização de parceiros e clientes, serão inicialmente de responsabilidade dos sócios.

O quadro a seguir esclarece a função de cada funcionário e suas responsabilidades a partir do Ano 2:

Quadro 18 - Cargos e funções dos funcionários para o ano 2

\begin{tabular}{|l|l|}
\hline Cargo & Função \\
\hline Gerente administrativo e financeiro & $\begin{array}{l}\text { Responsável pelos serviços } \\
\text { administrativos junto ao escritório contábil, } \\
\text { pelo planejamento financeiro e } \\
\text { contratação de pessoal. }\end{array}$ \\
\hline Gerente comercial & $\begin{array}{l}\text { Responsável pelo marketing, negociação } \\
\text { e departamento de vendas. Nos eventos, } \\
\text { realizará também a função de } \\
\text { coordenador de cerimonial. }\end{array}$ \\
\hline Auxiliar administrativo & $\begin{array}{l}\text { Serviços administrativos auxiliares } \\
\text { Promotor de vendas }\end{array}$ \\
\hline Secretária & $\begin{array}{l}\text { Responsável pela divulgação da empresa } \\
\text { na cidade e região, e pela concretização } \\
\text { de parceiros e clientes. }\end{array}$ \\
\hline $\begin{array}{l}\text { Atendimento ao cliente, cadastro de } \\
\text { parceiros e clientes, telefone, entre outros. }\end{array}$ \\
\hline
\end{tabular}

Os salários dos colaboradores estarão definidos de acordo com o mercado, o nível de escolaridade e o cargo.

A cada evento será contratado um mestre de cerimônias, recepcionistas e demais funcionários. Estes, porém, não terão vínculo com a empresa, sendo os dois coordenadores de eventos, inicialmente, os gerentes. Os valores pagos pelos serviços desses profissionais serão de acordo com o mercado.

As pessoas contratadas como recepcionistas de eventos serão, preferencialmente, estagiárias dos cursos de turismo e comunicação. 


\subsection{PLANO FINANCEIRO}

Salim et al (2005, p. 105) considera o planejamento financeiro importante porque:

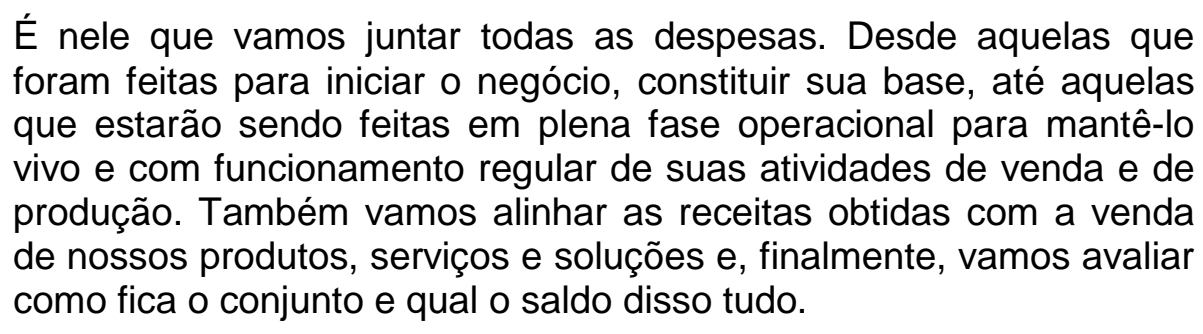

Ainda segundo Salim et al (2005, p. 105), o planejamento financeiro deverá responder às seguintes perguntas:

1. A empresa é lucrativa?

2. Depois de quanto tempo após a sua constituição?

3. Quanto será necessário investir para que seja possível chegar ao ponto em que a empresa seja auto-sustentável?

\subsubsection{Investimento Inicial}

Levantar-se-ão os gastos iniciais básicos para a abertura da empresa nessa etapa do Plano de Negócio. Os valores descritos foram calculados a partir de uma pesquisa de preços na cidade de Dourados-MS, e consultando as tabelas de determinados órgãos municipais e estaduais.

- Os valores demonstrados na seção de serviços contábeis são os destinados à abertura da firma no município e no estado, e foram fornecidos por uma empresa de contabilidade local.

- Os valores destinados à mobília foram pesquisados diretamente com os fornecedores e em lojas comerciais da cidade. 
- Os valores para a instalação da internet nos quatro computadores da empresa foram baseados de acordo com o mercado local.

- Os valores destinados às obras da sala foram baseados nos preços cobrados por profissionais da área, na cidade de Dourados-MS.

- Os valores destinados ao marketing foram baseados, inicialmente, na confecção de folders, e na criação do site, respeitando valores de mercado.

Tabela 4 - Investimento Inicial

\begin{tabular}{|c|c|c|c|}
\hline Serviços contábeis & Quantidade & Valor Unitário & Valor total \\
\hline Junta comercial & 01 & 204,50 & 204,50 \\
\hline DAEMS & 01 & 5,17 & 5,17 \\
\hline IE & 01 & 150,00 & 150,00 \\
\hline Alvará de localização & 01 & 50,00 & 50,00 \\
\hline \multirow[t]{2}{*}{ Alvará sanitário } & 01 & 65,00 & 65,00 \\
\hline & & Total & 474,67 \\
\hline \multicolumn{4}{|l|}{ Mobília } \\
\hline Computadores & 04 & $1.000,00$ & $4.000,00$ \\
\hline $\begin{array}{l}\text { Aparelho } \\
\text { Multifuncional HP }\end{array}$ & 01 & 450,00 & 450,00 \\
\hline Aparelho telefônico & 02 & 70,00 & 140,00 \\
\hline Ar condicionado & 01 & 699,00 & 699,00 \\
\hline Mesas de trabalho & 04 & 270,00 & $1.080,00$ \\
\hline Mesa para reunião & 01 & 250,00 & 250,00 \\
\hline Cadeira reunião & 06 & 59,00 & 354,00 \\
\hline $\begin{array}{l}\text { Cadeira de escritório } \\
\text { giratória com braço }\end{array}$ & 06 & 174,00 & $1.044,00$ \\
\hline Bebedouro & 01 & 350,00 & 350,00 \\
\hline \multirow[t]{2}{*}{ Armário/ arquivo } & 01 & 359,00 & 359,00 \\
\hline & & Total & $8.726,00$ \\
\hline \multicolumn{4}{|l|}{ Instalação Internet } \\
\hline Modem ADSL & 01 & 100,00 & 100,00 \\
\hline HUB 8 portas & 01 & 80,00 & 80,00 \\
\hline Cabos & 04 & 1,00 o metro & 40,00 \\
\hline \multirow[t]{2}{*}{ Mão de obra } & 01 & 100,00 o ponto & 400,00 \\
\hline & & Total & 620,00 \\
\hline Obras & & & \\
\hline
\end{tabular}




\begin{tabular}{l|l|l|l}
\hline Pintura da sala & 01 & 350,00 & 350,00 \\
\hline $\begin{array}{l}\text { Instalação do ar } \\
\text { condicionado }\end{array}$ & 01 & 300,00 & 300,00 \\
\hline \multicolumn{1}{c|}{ Marketing } & & Total & $\mathbf{6 5 0 , 0 0}$ \\
\hline $\begin{array}{l}\text { Material divulgação } \\
\text { Criação do Site }\end{array}$ & ----- & ----- & \\
\hline & 01 & 600,00 & $2.700,00$ \\
\hline & & Total & 600,00 \\
\hline
\end{tabular}

\subsubsection{Desembolsos operacionais}

O custo mensal da empresa Supera Produções está descrito a seguir:

4.6.2.1 Remuneração e encargos

Conforme dados sugeridos por um escritório de contabilidade da cidade de Dourados-MS, os salário e encargos serão descritos da seguinte forma:

Tabela 5 - Remunerações e encargos para o ano 1

\begin{tabular}{l|l|l|l|l|l}
\hline Despesas com pessoal & \multicolumn{1}{|c|}{$\begin{array}{c}\text { Encargos } \\
\text { FGTS (\%) }\end{array}$} & $\begin{array}{c}\text { Encargo } \\
\text { s INSS } \\
(\%)\end{array}$ & $\begin{array}{c}\text { Remuneração } \\
\text { mensal (R\$) }\end{array}$ & $\begin{array}{c}\text { Encargos para } \\
\text { a empresa } \\
\text { (R\$) }\end{array}$ & $\begin{array}{c}\text { Encargos do } \\
\text { funcionário } \\
\text { (R\$) }\end{array}$ \\
\hline $\begin{array}{l}\text { Sócio Gerente } \\
\text { administrativo/ financeiro }\end{array}$ & & $11 \%$ & $\mathrm{R} \$ 350,00$ & & $\mathrm{R} \$ 38,50$ \\
\hline Sócio Gerente comercial & & $11 \%$ & $\mathrm{R} \$ 350,00$ & & $\mathrm{R} \$ 38,50$ \\
\hline Auxiliar administrativo & Estagiário & & $\mathrm{R} \$ 500,00$ & Estagiário & \\
\hline Secretária & Estagiário & & $\mathrm{R} \$ 500,00$ & Estagiário & \\
\hline
\end{tabular}

Total geral remuneração + encargos para a empresa $=\mathbf{R} \$ 1.700,00$ 
Tabela 6 - Remunerações e encargos para o ano 2

\begin{tabular}{l|l|l|l|l|l}
\hline Despesas com pessoal & $\begin{array}{l}\text { Encargos } \\
\text { FGTS (\%) }\end{array}$ & $\begin{array}{l}\text { Encargos } \\
\text { INSS (\%) }\end{array}$ & $\begin{array}{l}\text { Remuneração } \\
\text { mensal (R\$) }\end{array}$ & $\begin{array}{l}\text { Encargos para } \\
\text { a empresa } \\
(\mathbf{R} \$)\end{array}$ & $\begin{array}{l}\text { Encargos do } \\
\text { funcionário } \\
(\mathbf{R} \$)\end{array}$ \\
\hline $\begin{array}{l}\text { Gerente administrativo/ } \\
\text { financeiro }\end{array}$ & & $11 \%$ & $\mathrm{R} \$ 350,00$ & & 38,50 \\
\hline Gerente comercial & & $11 \%$ & $\mathrm{R} \$ 350,00$ & & 38,50 \\
\hline Promotor de vendas & $8 \%$ & $7,65 \%$ & $\mathrm{R} \$ 800,00$ & 64,00 & 61,20 \\
\hline Auxiliar administrativo & $8 \%$ & $7,65 \%$ & $\mathrm{R} \$ 700,00$ & 56,00 & 53,55 \\
\hline Secretária & $8 \%$ & $7,65 \%$ & $\mathrm{R} \$ 700,00$ & 56,00 & 53,55 \\
\hline
\end{tabular}

Total geral remuneração + encargos para a empresa $=\mathbf{R} \$ \mathbf{2 . 3 7 6 , 0 0}$

Os gerentes receberão o pró-labore de $R \$ 350,00$, e pagarão $R \$ 38,50$ de INSS cada - alternativa escolhida com intenção de minimizar gastos, pois são sócios e terão o lucro líquido da empresa dividido conforme contrato elaborado. Observa-se que o total geral de remuneração e encargos exclui os salários da gerência.

O Promotor de vendas, com condução própria, inicialmente não terá comissão, e fará parte do quadro fixo de funcionários da empresa, recebendo auxílio-combustível para viagens e visitas externas, e auxílio-alimentação em viagens e hospedagem, quando necessário.

A partir do ano 2 os funcionários do quadro fixo receberão o $13^{\circ}$ salário e as férias, sendo que o primeiro foi dividido em 2 vezes, e o outro constará na planilha de fluxo de caixa somente no ano 3 , que não foi desenvolvida nesse trabalho.

As despesas mensais estão demonstradas a seguir.

Tabela 7 - Despesas mensais para o ano 1

\begin{tabular}{l|l}
\hline Despesas Mensais & Valor (R\$) \\
\hline Telefone + internet & 200,00 \\
\hline Condomínio (água e energia) & 70,00 \\
\hline Despesa combustível & 300,00 \\
\hline Despesa pessoal com encargos & $1.700,00$ \\
\hline Manutenção do site & 175,00 \\
\hline Material de escritório & 60,00 \\
\hline Escritório de Contabilidade & 350,00 \\
\hline
\end{tabular}




\begin{tabular}{l|l}
\hline Despesas operacionais & 100,00 \\
\hline Total & $\mathbf{2 . 9 5 5 , 0 0}$ \\
\hline
\end{tabular}

Tabela 8 - Despesas mensais para o ano 2

\begin{tabular}{l|c}
\hline Despesas Mensais & Valor (R\$) \\
\hline Telefone + internet & 250,00 \\
\hline Condomínio (água e energia) & 70,00 \\
\hline Despesa combustível & 300,00 \\
\hline Despesa pessoal com encargos & $2.376,00$ \\
\hline Manutenção do site & 175,00 \\
\hline Material de escritório & 100,00 \\
\hline Escritório de Contabilidade & 350,00 \\
\hline Despesas operacionais & 200,00 \\
\hline Total & $\mathbf{3 . 8 2 1 , 0 0}$ \\
\hline
\end{tabular}

O pagamento a terceiros e a geração de impostos também estão inclusos como despesa mensal nos dois anos aqui projetados.

\subsubsection{Faturamento}

O faturamento mensal da empresa foi desenvolvido considerando a seguinte projeção de vendas.

Quadro 19 - Projeção de vendas

\begin{tabular}{|l|l|l|l|l|l|l|l|l|l|l|l|l|}
\hline Ano 1 & $\begin{array}{l}\text { Mês } \\
\mathbf{1}\end{array}$ & $\begin{array}{l}\text { Mês } \\
\mathbf{2}\end{array}$ & $\begin{array}{l}\text { Mês } \\
\mathbf{3}\end{array}$ & $\begin{array}{l}\text { Mês } \\
\mathbf{4}\end{array}$ & $\begin{array}{l}\text { Mês } \\
\mathbf{5}\end{array}$ & $\begin{array}{l}\text { Mês } \\
\mathbf{6}\end{array}$ & $\begin{array}{l}\text { Mês } \\
\mathbf{7}\end{array}$ & $\begin{array}{l}\text { Mês } \\
\mathbf{8}\end{array}$ & $\begin{array}{l}\text { Mês } \\
\mathbf{9}\end{array}$ & $\begin{array}{l}\text { Mês } \\
\mathbf{1 0}\end{array}$ & $\begin{array}{l}\text { Mês } \\
\mathbf{1 1}\end{array}$ & $\begin{array}{l}\text { Mês } \\
\mathbf{1 2}\end{array}$ \\
\hline Casamento & & & 1 & 1 & 2 & & & & & & & \\
\hline Festa de debutante & & & & & & & & 1 & & 1 & 1 & \\
\hline Formatura & & & & 1 & & & 1 & & 1 & & & \\
\hline Ano 2 & $\mathbf{1}$ & $\begin{array}{l}\text { Mês } \\
\mathbf{2}\end{array}$ & $\begin{array}{l}\text { Mês } \\
\mathbf{3}\end{array}$ & $\begin{array}{l}\text { Mês } \\
\mathbf{4}\end{array}$ & $\begin{array}{l}\text { Mês } \\
\mathbf{5}\end{array}$ & $\begin{array}{l}\text { Mês } \\
\mathbf{6}\end{array}$ & $\begin{array}{l}\text { Mês } \\
\mathbf{7}\end{array}$ & $\begin{array}{l}\text { Mês } \\
\mathbf{8}\end{array}$ & $\begin{array}{l}\text { Mês } \\
\mathbf{9}\end{array}$ & $\begin{array}{l}\text { Mês } \\
\mathbf{1 0}\end{array}$ & $\begin{array}{l}\text { Mês } \\
\mathbf{1 1}\end{array}$ & $\begin{array}{l}\text { Mês } \\
\mathbf{1 2}\end{array}$ \\
\hline Casamento & 1 & $\mathbf{1}$ & & $\mathbf{2}$ & & 1 & 1 & & & & & \\
\hline Festa de debutante & & & 1 & & 1 & & & 1 & 2 & 1 & 1 & \\
\hline Formatura & & 1 & 1 & & & 1 & & 2 & & 1 & 1 & \\
\hline
\end{tabular}


Totalizando no ano 1 dez eventos, e no ano 2 vinte eventos - ou seja, o dobro do primeiro ano.

A projeção de vendas foi desenvolvida aleatoriamente, eximindo-se de fatores climáticos, econômicos, governamentais ou sociais.

\subsubsection{Fluxo de caixa}

Para Salim et al (2005, p. 110), o fluxo de caixa

Representa a evolução das entradas e saídas de recursos financeiros da empresa ao longo do tempo, de forma a visualizar, a cada momento, a disponibilidade líquida do caixa e verificar se os desembolsos futuros poderão ser efetuados nas datas previstas.

Ele foi elaborado a partir da projeção de vendas de dez eventos no primeiro ano e vinte no segundo ano. As vendas foram todas efetuadas no máximo de parcelas de cada pacote, ou seja, a formatura em 12, e a festa, boda e casamento em 4 vezes. (vide apêndice)

\subsubsection{Indicadores}

4.6.5.1 Taxa Interna de Retorno (TIR)

"Também chamada Internal Rate of Return (IRR), representa a taxa de desconto que iguala, em um único momento, os fluxos de entrada com os de saída de caixa." (Salim et al, 2005, p. 297). 
Conforme a tabela de fluxo de caixa em apêndice, é apresentada uma Taxa Interna de Retorno (TIR) de 13\% ao ano, ou seja, o investimento está sendo remunerado a $13 \%$ ao ano. Portanto, fica demonstrada a viabilidade do negócio, uma vez que a TIR apresenta um valor maior que o da taxa de juros de $12 \%$ ao ano.

\subsubsection{Ponto de Equilíbrio}

Sanvicente (1997, p. 193) compreende o ponto de equilíbrio como sendo "aquele nível ou volume de produção (ou atividade, em caso de empresa não industrial) em que o resultado operacional é nulo, ou seja, as receitas operacionais são exatamente iguais ao valor total das despesas operacionais". Santos (2001, p. 232) complementa: "Quando as vendas da empresa se situarem acima do ponto de equilíbrio, ela começará a ter lucro".

É interessante colocar as definições de custo fixo e variável, já que se faz necessária sua identificação ao analisar-se o ponto de equilíbrio da atividade da empresa. Assim, para Sanvicente (1997, p. 196), o primeiro é "todo aquele item de custo ou despesa que não varia, em valor total, com o volume de atividade ou operação", enquanto "custo variável é aquele que se altera em relação direta com as modificações do volume de atividade".

Os custos fixos e variáveis da Supera Produções está descrito a seguir.

Tabela 9 - Custos fixos e variáveis

\begin{tabular}{l|l|l}
\hline Custos Fixos & Ano 1 & Ano 2 \\
\hline IPTU & 332,00 & 332,00 \\
\hline Manutenção do site & $2.100,00$ & $2.100,00$ \\
\hline Pessoal e encargos & $20.400,00$ & $28.512,00$ \\
\hline Férias e 13 & --- & $2.376,00$ \\
\hline Serviços contábeis & $4.200,00$ & $4.200,00$ \\
\hline Total & $\mathbf{2 7 . 0 3 2 , 0 0}$ & $\mathbf{3 7 . 5 2 0 , 0 0}$ \\
\hline
\end{tabular}




\begin{tabular}{l|l|l}
\hline Custos Variáveis & Ano 1 & Ano 2 \\
\hline Condomínio (água, energia) & 840,00 & 840,00 \\
\hline Despesas Operacionais & $1.200,00$ & $2.400,00$ \\
\hline Telefone & $2.400,00$ & $3.000,00$ \\
\hline Despesas de combustível & $3.600,00$ & $3.600,00$ \\
\hline Material de escritório e diversos & 720,00 & $1.200,00$ \\
\hline Pagamentos a parceiros & $233.107,26$ & $454.293,44$ \\
\hline Encargos Tributários & $2.110,81$ & $12.903,71$ \\
\hline Total & $\mathbf{2 4 3 . 9 7 8 , 0 7}$ & $\mathbf{4 7 8 . 2 3 7 , 1 5}$ \\
\hline
\end{tabular}

Deve-se calcular o ponto de equilíbrio em volume de vendas, pois a empresa possui variados produtos e serviços. Destarte, de acordo com Santos (2001, p. 235), será considerada a seguinte fórmula:

$$
P Q=\frac{F}{M C}
$$

Onde:

Q= Quantidade Vendida

$\mathrm{F}=$ Custo Fixo Total

$M C=$ Margem de Contribuição

$\mathrm{MC}=$ Receita Total - Custo Variável Total

\section{Receita Total}

Avaliando a planilha de fluxo de caixa, temos:

$$
\begin{aligned}
& M C=\frac{965.447,32-722 \cdot 215,22}{965.447,32}=0,25=25 \% \\
& P Q=\frac{64.552}{0,25}=258.208,00 \text { (Ponto de Equilíbrio) }
\end{aligned}
$$


Quando a empresa estiver operando com um volume de vendas acima de 258.208,00 ela estará gerando lucro.

\subsubsection{Período de Payback (Tempo de Retorno)}

"É o período de recuperação de um investimento. Ou seja, o prazo até que o investimento inicial seja recuperado por meio de fluxos de caixa líquidos positivos gerados pelo negócio”. (Salim et al, 2005 p. 298).

"Se os fluxos monetários não forem uniformes, o tempo de retorno acontecerá no período em que seus valores acumulados (entradas de caixa ou lucros contábeis) igualarem ao valor do investimento." (Santos, 2001 p. 150).

Analisando-se a planilha de fluxo de caixa da empresa, nota-se que 0 payback - ou tempo de retorno - ocorrerá no mês três do segundo ano, quando a soma do fluxo operacional líquido iguala-se ao valor do investimento. 


\section{CONSIDERAÇÕES FINAIS}

A criação de um plano de negócio antecedendo a criação da empresa demonstra-se de grande importância para organizar idéias, traçar objetivos e criar estratégias. Os dados aqui analisados comprovam a relevância desse documento, já que, uma vez demonstrados os riscos, minimizam-se as incertezas, e, consequentemente, as possibilidades de insucesso da empresa, bem como ele permite antever as chances que o mercado oferece, maximizando, então, as possibilidades de perpetuação do empreendimento.

Esse trabalho teve como objetivo geral a verificação da viabilidade do negócio, guiando-se pelos objetivos específicos de conhecer o sistema de planejamento da área de eventos, e realizar uma análise de campo para o desenvolvimento do plano de negócio. Para tanto, baseou-se nas duas hipóteses existentes: a positiva - se a implantação de uma empresa de eventos na cidade de Dourados seria viável -, e a negativa, em contraposição, demonstrando-se a viabilidade da primeira. O problema de pesquisa, também nessa mesma linha, questiona sobre a viabilidade da criação do empreendimento na cidade.

Com isso, a partir da análise das quatro etapas do Plano de Negócio, verificou-se que no plano estratégico foi definida a identidade da empresa, estabelecendo-se os objetivos, as metas, os valores, formulando-se as estratégias, organizando-se os produtos e serviços, bem como, identificando seu diferencial como a organização de eventos sociais de maneira inovadora, ao utilizar elementos inusitados, estimulando o lúdico, como, por exemplo, no pacote de formatura, com inserções de músicas dançantes e chuva de papel picado no final da colação de grau - assim como a contratação de um ator para mestre de cerimônias, encarregado de executar performance no decorrer do baile de formatura.

No plano de marketing foi analisado o mercado e o ambiente, verificando-se as oportunidades, ameaças, pontos fracos e pontos fortes, bem como identificandose os concorrentes e estabelecendo-se estratégias. Confrontando os dados da Supera Produções com a realidade, notou-se que as empresas concorrentes, 
embora estejam consolidadas no mercado, ainda deixam um espaço para inovação e flexibilidade, o qual a empresa em questão pretende ocupar.

No plano operacional foi desenvolvida a estrutura física e organizacional da empresa, definido-se o número de funcionários e cargos nos dois primeiros anos. Como a Supera Produções produzirá eventos diferenciados, o quadro de funcionários - tanto fixo quanto temporário - estará em constante treinamento e reciclagem.

$\mathrm{Na}$ análise financeira, em que se estabelece o investimento inicial, a projeção de custos, bem como a projeção de vendas - conforme indicações no fluxo de caixa -, foram verificados alguns indicadores de viabilidade, como a TIR (Taxa Interna de Retorno), o ponto de equilíbrio e período de Payback. Notou-se, por fim, que durante o segundo ano de existência da empresa ela passa a obter lucro, onde pode-se perceber a equalização do investimento com o fluxo operacional líquido. A Taxa Interna de Retorno de 13\% mostrou-se maior que a taxa de juros, enquanto o ponto de equilíbrio, embora alto, favorece a viabilidade do negócio.

Conclui-se que os resultados obtidos através dos estudos de planejamento, análises, projeções e estimativas do setor de eventos na região de Dourados levam à viabilidade da empresa Supera Produções. 


\section{REFERÊNCIAS BIBLIOGRÁFICAS}

ABEOC - Associação Brasileira de Empresas de Eventos. <http://www.abeoc.org.br/20060724123307.php >, Acesso em: Jan. 2007.

ACERENZA, Miguel Angel. Administração do Turismo. V.1. Bauru, SP: Edusc, 2002.

Administração do Turismo. V.2. Bauru, SP: Edusc, 2003.

ANDRADE, José Vicente. Turismo: Fundamentos e Dimensões. São Paulo, SP: Ática, 1998.

AZEVEDO, Sérgio. Guia Valor Econômico de Marketing para Pequenas e Médias empresas. São Paulo: Globo, 2002.

BADARÓ, Rui Aurélio de Lacerda. O direito do turismo através da história e sua evolução.

Disponível

em $<$ http://www.ibcdtur.org.br/arquivos/DireitoDoTurismoHist.pdf>. Acesso em: Out. 2006.

BAHL. Miguel. Perspectivas do turismo na sociedade pós-industrial. São Paulo, SP: Roca. 2003.

. Turismo: Enfoques teóricos e práticos. São Paulo, SP: Roca, 2003.

BARBOSA, L., ZOUAIN, D. Gestão em Turismo e Hotelaria: Experiências públicas e privadas. São Paulo, AP: Aleeph, 2004. 
BANGS, David. Guia pratico : Planejamento de negocios: criando um plano para o seu negocio ser bem-sucedido. Sao paulo : Nobel, 1999.

BENI, Mario Carlos. Análise estrutural do turismo. São Paulo: SENAC,1998.

BRITTO, J., FONTES, N. Estratégias para Eventos: Uma ótica do Marketing e do Turismo. São Paulo, SP: Aleph, 2002.

CASASOLA, Luís. Turismo e ambiente. São Paulo: Roca, 2003.

COBRA, Marcos. Plano Estratégico de Marketing. São Paulo: Atlas, 1995.

COSTA, Eliezer. Gestão Estratégica. São Paulo: Saraiva, 2003.

DENCKER. Ada. Métodos e Técnicas de pesquisa em Turismo. São Paulo. Futura, 2004

DIAS, Sergio Roberto. Análise de Mercado. In: São Paulo: Saraiva, 2006. (org). Gestão de Marketing.

DOLABELA, Fernando. Oficina do Empreendedor. São Paulo, SP: Cultura, 1999. . O Segredo de Luisa. São Paulo, SP: Cultura, 1999.

FREUND, Francisco. Festas e Recepções. Rio de Janeiro, RJ: Senac nacional, 2002. 
FTE - Faculdade de Tecnologia Empresarial. Curso de Gestão de Empresas de Eventos. Salvador, BA. 2006.

GIÁCOMO, Cristina. Tudo acaba em festa: evento, líder de opinião pública. 2. ed. São Paulo: Scritta, 1997.

IBRADEP - Instituto Brasileiro de Desenvolvimento, Aperfeiçoamento e Capacitação Profissional <http://www.ibradep.com.br/articulista_gilda43.htm> Acesso em: Jan. 2007.

INAE - Instituto Nacional de Altos Estudos< http://inae.org.br/publi/ep/EP0138.pdf> Acesso em: Jan. 2007.

SKACEL, Robert K. Plano de Marketing. São Paulo: Nobel, 1992.

KOTLER, Philip. Administração de Marketing: análise, planejamento e controle. São Paulo: Atlas, 1988.

KOTLER, P., BLOOM, P. Marketing para serviços profissionais. São Paulo: Atlas, 1988.

LINS, Augusto. Etiqueta, Protocolo e Cerimonial. Brasília, DF: Linha Gráfica, 1991.

LONGENECKER, J. MOORE, C. PETTY, J. Administração de pequenas empresas. São Paulo, SP: Makron Books, 1997.

LAS CASAS, Alexandre Luzzi. Plano de Marketing para micro e pequena empresa. São Paulo: Atlas, 2001. 
LIMEIRA, Tânia. Fundamentos de Marketing. In: Dias, Sergio Roberto (org). Gestão de Marketing. São Paulo: Saraiva, 2006.

MARCONI, M. LAKATOS, E. Fundamentos de metodologia cientifica. São Paulo: Atlas, 2001.

MATIAS. Marlene. Organização de Eventos: Procedimentos e Técnicas. Barueri, SP: Manole, 2004.

MEIRELLES. Gilda. Tudo Sobre Eventos. São Paulo, SP: STS, 1999.

Ministério

do

Turismo.

http://institucional.turismo.gov.br/portalmtur/opencms/institucional/legislacao/arquivos /resolucao_normativa_CNTUR_n_14_84_23_novembro_1984.html>, Acesso em: Mar 2007. /decreto_n_89.707_84_25_marxo_1984> Acesso em: Mar 2007.

OLIVEIRA, Claudionor. Metodologia Científica, Planejamento e Técnicas de Pesquisa. São Paulo, SP: LTr, 2000.

OLIVEIRA, Djalma. Excelência na administração estratégica. São Paulo: Atlas, 1997.

. Planejamento Estratégico: Conceitos, Metodologia e Práticas. São Paulo: Atlas, 1998. 
OMT. Organização Mundial do Turismo <http://www.worldtourism.org/facts/eng/methodological.htm\#2> Acesso em: Dez. 2006.

PADUA, Elisabete. Metodologia da Pesquisa. Abordagem teórica-prática. Campinas, SP, 2000.

PETROCCHI, Mario. Gestão de Pólos Turísticos. São Paulo, SP: Futura, 2002.

PROATUR- Programa de apoio ao turismo regional < http://www.integracao.gov.br/fundos/fundos_constitucionais/fne/programacao/2004/s etor_proatur_turismo_regional.asp> Acesso em: Jan. 2007.

RANGEL, Alexandre. A Sabedoria das Parábolas na Alta Administração. Contagem, MG: Leitura, 2005.

RISPOLI, Reginaldo. Produção de Eventos. Brasília, DF: Teixeira.

RUSCHMANN, Dóris. Turismo e Planejamento Sustentável. 8 ${ }^{\underline{a}}$ ed. São Paulo: Papirus, 2001.

SALIM, C., Hochman, N., RAMAL, A., RAMAL, S. Construindo Planos de Negócios. Rio de Janeiro, RJ: Elsevier, 2005.

SANTOS, Edno. Administração Financeira da Pequena e Média Empresa. São Paulo, SP: Atlas, 2001.

SANVICENTE, Antônio. Administração Financeira. São Paulo, SP: Atlas, 1997. 
SEBRAE<http://www.biblioteca.sebrae.com.br/bds/BDS.nsf/21262149D58AFA2B032 56EC40065F4C4/\$File/NT00073BCA.pdf> Acesso em: Jan. 2007.

SEBRAE<http://www.biblioteca.sebrae.com.br/bds/BDS.nsf/BD923291670360C7032 56F29004F48FE/\$File/Planejamento\%20estrat\%C3\%A9gico.pdf> Acesso em: Jan. 2007

SEBRAE<http://www.biblioteca.sebrae.com.br/bds/BDS.nsf/6D107C364C290250032 56FEB00674C55/\$File/NT000A6B6A.pdf> Acesso em: Jan. 2007

SEBRAE<http://www.biblioteca.sebrae.com.br/bds/BDS.nst/4CB0B615A061784F032 56ED9007244B5/\$File/NT00085F62.pdf> Acesso em: Jan. 2007

TIFFANY, P. PETERSON, S. Planejamento Estratégico. Rio de Janeiro, RJ: Campus, 1999.

TORRE, De la. El Turismo: fenômeno social. México. Fondo de Cultura Econômica, 1992.

WEINTEIN, Art. Segmentação de mercado. São Paulo: Atlas, 1995. 
APÊNDICES 
APÊNDICE A - Planilha de Fluxo de caixa Ano 1 


\begin{tabular}{|c|c|c|c|c|c|c|c|c|c|c|c|c|c|}
\hline Fluxo de Caixa - Ano 1 & & & & & & & & & & & & & \\
\hline & & & & & & & & & & & & & \\
\hline \multicolumn{14}{|l|}{ SUPERA Produções } \\
\hline Discriminação & Mês 0 & Mês 1 & Mês2 & Mês 3 & Mês 4 & Mês 5 & Mês 6 & Mês 7 & Mês 8 & Mês9 & Mês 10 & Mês 11 & Mês 12 \\
\hline \multicolumn{14}{|l|}{ I. Atividades Operacionais } \\
\hline \multicolumn{14}{|l|}{ Embolsos Operacionais (a) } \\
\hline \multicolumn{14}{|l|}{ Receitas em venda } \\
\hline Boda/Casamento & & & & $\mathrm{R} \$ \quad 6.661,44$ & $\mathrm{R} \$ 13.322,88$ & $\mathrm{R} \$ 26.645,76$ & $\mathrm{R} \$ 26.645,76$ & $\mathrm{R} \$ 19.984,32$ & $\mathrm{R} \$ 13.322,88$ & & & & \\
\hline Festa de Debutante & & & & & & & & & $\mathrm{R} \$ \quad 6.326,44$ & $\mathrm{R} \$ \quad 6.326,44$ & $\mathrm{R} \$ 12.652,88$ & $\mathrm{R} \$ 18.979,32$ & $\mathrm{R} \$ 12.652,88$ \\
\hline Formatura & & & & & $\mathrm{R} \$ \quad 5.719,75$ & $\mathrm{R} \$ \quad 5.719,75$ & $\mathrm{R} \$ \quad 5.719,75$ & $\mathrm{R} \$ 11.439,50$ & $\mathrm{R} \$ 11.439,50$ & $\mathrm{R} \$ 17.159,25$ & $\mathrm{R} \$ 17.159,25$ & $\mathrm{R} \$ 17.159,25$ & $\mathrm{R} \$ 17.159,25$ \\
\hline Total Receita & & & & $\mathrm{R} \$ \mathbf{6 . 6 6 1 , 4 4}$ & $\mathrm{R} \$ 19.042,63$ & $\mathrm{R} \$ 32.365,51$ & $\mathrm{R} \$ 32.365,51$ & $\mathrm{R} \$ \mathbf{3 1 . 4 2 3 , 8 2}$ & R\$ 31.088,82 & R\$ 23.485,69 & $\mathrm{R} \$ 2 \mathbf{2 9 . 8 1 2 , 1 3}$ & $\mathrm{R} \$ \mathbf{3 6 . 1 3 8 , 5 7}$ & $\mathrm{R} \$ 29.812,13$ \\
\hline \multicolumn{14}{|l|}{ Desembolsos Operacionais (b) } \\
\hline Investimento inicial & $\mathrm{R} \$ \quad(13.770,67)$ & & & & & & & & & & & & \\
\hline Despesas Operacionais & $\mathrm{R} \$ \quad(100,00)$ & $\mathrm{R} \$ \quad(100,00)$ & $\mathrm{R} \$ \quad(100,00)$ & $\mathrm{R} \$ \quad(100,00)$ & $\mathrm{R} \$ \quad(100,00)$ & $\mathrm{R} \$ \quad(100,00)$ & $\mathrm{R} \$ \quad(100,00)$ & $\begin{array}{|ll|}\mathrm{R} \$ \quad(100,00) \\
\end{array}$ & $\mathrm{R} \$ \quad(100,00)$ & $\mathrm{R} \$ \quad(100,00)$ & $\mathrm{R} \$ \quad(100,00)$ & R\$ $\quad(100,00)$ & $\mathrm{R} \$ \quad(100,00)$ \\
\hline Condominio (água, energia) & & $\mathrm{R} \$ \quad(70,00)$ & $\mathrm{R} \$ \quad(70,00)$ & $\mathrm{R} \$ \quad(70,00)$ & $\mathrm{R} \$ \quad(70,00)$ & $\mathrm{R} \$ \quad(70,00)$ & $\mathrm{R} \$ \quad(70,00)$ & $\mathrm{R} \$ \quad(70,00)$ & $\mathrm{R} \$ \quad(70,00)$ & $\mathrm{R} \$ \quad(70,00)$ & $\mathrm{R} \$ \quad(70,00)$ & $\mathrm{R} \$ \quad(70,00)$ & $\mathrm{R} \$ \quad(70,00)$ \\
\hline IPTU & $\mathrm{R} \$ \quad(166,00)$ & & & & & & & & & & & & \\
\hline Telefone & & $\mathrm{R} \$ \quad(200,00)$ & $\mathrm{R} \$ \quad(200,00)$ & $\mathrm{R} \$ \quad(200,00)$ & $\mathrm{R} \$ \quad(200,00)$ & $\mathrm{R} \$ \quad(200,00)$ & R\$ $\quad(200,00)$ & $\mathrm{R} \$ \quad(200,00)$ & $\mathrm{R} \$ \quad(200,00)$ & $\mathrm{R} \$ \quad(200,00)$ & $\mathrm{R} \$ \quad(200,00)$ & R\$ $\quad(200,00)$ & $\mathrm{R} \$ \quad(200,00)$ \\
\hline Manutenção do site & & $\mathrm{R} \$ \quad(175,00)$ & $\mathrm{R} \$ \quad(175,00)$ & $\mathrm{R} \$ \quad(175,00)$ & $\mathrm{R} \$ \quad(175,00)$ & $\mathrm{R} \$ \quad(175,00)$ & R\$ $(175,00)$ & $\mathrm{R} \$ \quad(175,00)$ & $\mathrm{R} \$ \quad(175,00)$ & $\mathrm{R} \$ \quad(175,00)$ & $\mathrm{R} \$ \quad(175,00)$ & $\mathrm{R} \$ \quad(175,00)$ & $\mathrm{R} \$ \quad(175,00)$ \\
\hline Pessoal e encargos & & $\mathrm{R} \$(1.700,00)$ & $\mathrm{R} \$(1.700,00)$ & $\mathrm{R} \$(1.700,00)$ & $\mathrm{R} \$(1.700,00)$ & $\mathrm{R} \$(1.700,00)$ & $\mathrm{R} \$(1.700,00)$ & $\mathrm{R} \$(1.700,00)$ & $\mathrm{R} \$(1.700,00)$ & $\mathrm{R} \$(1.700,00)$ & $\mathrm{R} \$(1.700,00)$ & $\mathrm{R} \$(1.700,00)$ & $\mathrm{R} \$(1.700,00)$ \\
\hline \multicolumn{14}{|l|}{ Férias e $13^{\circ}$} \\
\hline Despesas de combustível & & $\mathrm{R} \$ \quad(300,00)$ & $\mathrm{R} \$ \quad(300,00)$ & $\begin{array}{ll}\mathrm{R} \$ \quad(300,00) \\
\end{array}$ & $\mathrm{R} \$ \quad(300,00)$ & $\mathrm{R} \$ \quad(300,00)$ & R\$ $\quad(300,00)$ & $\mathrm{R} \$ \quad(300,00)$ & \begin{tabular}{ll|}
$\mathrm{R} \$ \quad(300,00)$ \\
\end{tabular} & $\mathrm{R} \$ \quad(300,00)$ & $\mathrm{R} \$ \quad(300,00)$ & $\mathrm{R} \$ \quad(300,00)$ & $\mathrm{R} \$ \quad(300,00)$ \\
\hline Serviços contábeis & & $\mathrm{R} \$ \quad(350,00)$ & $\mathrm{R} \$ \quad(350,00)$ & $\mathrm{R} \$ \quad(350,00)$ & $\mathrm{R} \$ \quad(350,00)$ & $\mathrm{R} \$ \quad(350,00)$ & R\$ $(350,00)$ & $\mathrm{R} \$ \quad(350,00)$ & $\mathrm{R} \$ \quad(350,00)$ & $\mathrm{R} \$ \quad(350,00)$ & $\mathrm{R} \$ \quad(350,00)$ & R\$ $(350,00)$ & $\mathrm{R} \$ \quad(350,00)$ \\
\hline Material de escritório e diversos & & $\mathrm{R} \$ \quad(60,00)$ & $\mathrm{R} \$ \quad(60,00)$ & $\mathrm{R} \$ \quad(60,00)$ & $\mathrm{R} \$ \quad(60,00)$ & $\mathrm{R} \$ \quad(60,00)$ & R\$ $\quad(60,00)$ & $\mathrm{R} \$ \quad(60,00)$ & $\mathrm{R} \$ \quad(60,00)$ & $\mathrm{R} \$ \quad(60,00)$ & $\mathrm{R} \$ \quad(60,00)$ & R\$ $\quad(60,00)$ & $\mathrm{R} \$ \quad(60,00)$ \\
\hline $\begin{array}{l}\text { Encargos Tributários (COFINS, } \\
\text { PIS, ISS, IR, Contribuição social) }\end{array}$ & & & & $(49,15)$ & $(146,90)$ & $(245,20)$ & $(245,20)$ & $(244,65)$ & $(240,06)$ & $(190,35)$ & $(234,91)$ & $(279,47)$ & $(234,91)$ \\
\hline \multicolumn{14}{|l|}{ Pagamentos de Parceiros } \\
\hline Boda/ Casamento & & & & $\mathrm{R} \$(5.751,25)$ & $\begin{array}{c}\mathrm{R} \$ \\
(11.502,50)\end{array}$ & $\begin{array}{c}\mathrm{R} \$ \\
(23.005,00)\end{array}$ & $\begin{array}{c}\mathrm{R} \$ \\
(23.005,00)\end{array}$ & $\begin{array}{c}\mathrm{R} \$ \\
(17.253,75)\end{array}$ & $\begin{array}{c}\mathrm{R} \$ \\
(11.502,50)\end{array}$ & & & & \\
\hline Festa de debutante & & & & & & & & & $\mathrm{R} \$(5.501,25)$ & $\mathrm{R} \$(5.501,25)$ & $\begin{array}{c}\mathrm{R} \$ \\
(11.002,50) \\
\end{array}$ & $\begin{array}{c}\mathrm{R} \$ \\
(16.503,75) \\
\end{array}$ & $\begin{array}{c}\mathrm{R} \$ \\
(11.002,50) \\
\end{array}$ \\
\hline Formatura & & & & & $\mathrm{R} \$(4.819,79)$ & $\mathrm{R} \$(4.819,79)$ & $\mathrm{R} \$(4.819,79)$ & $\mathrm{R} \$(9.639,58)$ & $\mathrm{R} \$(9.639,58)$ & $\begin{array}{c}\mathrm{R} \$ \\
(14.459,37) \\
\end{array}$ & $\begin{array}{c}\mathrm{R} \$ \\
(14.459,37) \\
\end{array}$ & $\begin{array}{c}\mathrm{R} \$ \\
(14.459,37) \\
\end{array}$ & $\begin{array}{c}\mathrm{R} \$ \\
(14.459,37) \\
\end{array}$ \\
\hline Total Pagamento Parceiros & & & & $\begin{array}{c}\mathrm{R} \$ \\
(5.751,25) \\
\end{array}$ & $\begin{array}{c}\mathbf{R} \$ \\
(16.322,29) \\
\end{array}$ & $\begin{array}{c}\mathbf{R} \$ \\
(27.824,79) \\
\end{array}$ & $\begin{array}{c}\mathbf{R} \$ \\
(27.824,79) \\
\end{array}$ & $\begin{array}{c}\mathbf{R} \$ \\
(26.893,33) \\
\end{array}$ & $\begin{array}{c}R \$ \\
(26.643,33) \\
\end{array}$ & $\begin{array}{c}\mathbf{R} \$ \\
(19.960,62) \\
\end{array}$ & $\begin{array}{c}\mathbf{R} \$ \\
(25.461,87) \\
\end{array}$ & $\begin{array}{c}\mathbf{R} \$ \\
(30.963,12) \\
\end{array}$ & $\begin{array}{c}\mathbf{R} \$ \\
(25.461,87) \\
\end{array}$ \\
\hline Total Sáda & $R \$(14,036,67)$ & $\mathbf{R} \$(2.955,00)$ & $\mathbf{R} \$(2.955,00)$ & $\begin{array}{c}\mathrm{R} \$ \\
(8.356,25) \\
\end{array}$ & $\begin{array}{c}\mathrm{R} \$ \\
(19.074,19) \\
\end{array}$ & $\begin{array}{c}\mathrm{R} \$ \\
(30.674,99) \\
\end{array}$ & $\begin{array}{c}\mathrm{R} \$ \\
(28.974,99) \\
\end{array}$ & $\begin{array}{c}\mathrm{R} \$ \\
(29.742,98) \\
\end{array}$ & $\begin{array}{c}\mathrm{R} \$ \\
(29.488,39) \\
\end{array}$ & $\begin{array}{c}\mathrm{R} \$ \\
(22.755,97) \\
\end{array}$ & $\begin{array}{c}\mathrm{R} \$ \\
(28.301,78) \\
\end{array}$ & $\begin{array}{c}\mathrm{R} \$ \\
(33.847,59) \\
\end{array}$ & $\begin{array}{c}\mathrm{R} \$ \\
(28.301,78) \\
\end{array}$ \\
\hline $\begin{array}{l}\text { Fluxo Operacional Líquido } \\
\text { (c) = (a) - (b) }\end{array}$ & $\mathrm{R} \$(\mathbf{1 4 . 0 3 6 , 6 7 )}$ & $\mathbf{R} \$(2.955,00)$ & $\mathrm{R} \$(2.955,00)$ & $\mathrm{R} \$ 1.694,81$ & $\mathrm{R} \$ \quad 31,56$ & $\mathrm{R} \$ \quad 1.690,52$ & $\mathrm{R} \$ \mathbf{3 . 3 9 0 , 5 2}$ & $R \$ 1.680,84$ & $\mathrm{R} \$ \quad 1.600,43$ & $\mathbf{R} \$ \quad 729,72$ & $\mathrm{R} \$ 1.510,35$ & $\mathbf{R} \$ \quad 2.290,98$ & $\mathrm{R} \$ 1.510,35$ \\
\hline II. Atividades de Investimentos & & & & $\begin{array}{c}\mathrm{R} \$ \\
(14.506,65) \\
\end{array}$ & & & & & & & & & \\
\hline \multicolumn{14}{|l|}{ Embolsos de Investimentos (d) } \\
\hline $\begin{array}{l}\text { Rendimento de Aplicação } \\
\text { Financeira }\end{array}$ & $\mathrm{R} \$ \quad 30.000,00$ & $\mathrm{R} \$ 15.000,00$ & $\mathrm{R} \$ 12.000,00$ & $\mathrm{R} \$ \quad 9.950,00$ & $\mathrm{R} \$ 10.019,65$ & $\mathrm{R} \$ 10.089,79$ & $\mathrm{R} \$ 10.160,42$ & $\mathrm{R} \$ 10.231,54$ & $\mathrm{R} \$ 10.303,16$ & $\mathrm{R} \$ 10.375,28$ & $\mathrm{R} \$ 10.447,91$ & $\mathrm{R} \$ 10.521,04$ & $\mathrm{R} \$ 10.594,69$ \\
\hline \multicolumn{14}{|l|}{ Desembolsos de Investimentos (e) } \\
\hline Movimentação(poupança) & $\mathrm{R} \$ \quad(15.000,00)$ & $\mathrm{R} \$(3.000,00)$ & $\mathrm{R} \$(2.050,00)$ & & & & & & & & & & \\
\hline $\begin{array}{l}\text { Fluxo de Investimento Líquido } \\
\qquad(\mathrm{f})=(\mathrm{d}) \text { - (e) }\end{array}$ & $\mathrm{R} \$ \quad 15.000,00$ & $\mathrm{R} \$ 12.000,00$ & $\mathrm{R} \$ 9.950,00$ & $\mathrm{R} \$ \quad 9.950,00$ & $\mathrm{R} \$ 10.019,65$ & $\mathrm{R} \$ 10.089,79$ & $\mathrm{R} \$ 10.160,42$ & $\mathrm{R} \$ 10.231,54$ & $\mathrm{R} \$ 10.303,16$ & $\mathrm{R} \$ 10.375,28$ & $\mathrm{R} \$ 10.447,91$ & $\mathrm{R} \$ 10.521,04$ & $\mathrm{R} \$ 10.594,69$ \\
\hline $\begin{array}{l}\text { Caixa líquido do período } \\
\text { (g) }=(\mathrm{c})+(\mathrm{f})\end{array}$ & 963,33 & $\mathrm{R} \$ 9.045,00$ & $\mathrm{R} \$ \quad 6.995,00$ & $\mathrm{R} \$ 11.644,81$ & $\mathrm{R} \$ 10.051,21$ & $\mathrm{R} \$ 11.780,31$ & $\mathrm{R} \$ 13.550,94$ & $\mathrm{R} \$ 11.912,38$ & $\mathrm{R} \$ 11.903,59$ & $\mathrm{R} \$ 11.105,00$ & $\mathrm{R} \$ 11.958,25$ & $\mathrm{R} \$ 12.812,02$ & $\mathrm{R} \$ 12.105,04$ \\
\hline
\end{tabular}


APÊNDICE B - Planilha de Fluxo de caixa Ano 2 


\begin{tabular}{|c|c|c|c|c|c|c|c|c|c|c|c|c|}
\hline Fluxo de Caixa - Ano 2 & & & & & & & & & & & & \\
\hline \multicolumn{13}{|l|}{ SUPERA Produções } \\
\hline Discriminação & Mês 1 & Mês 2 & Mês 3 & Mês4 & Mês 5 & Mês 6 & Mês 7 & Mês 8 & Mês9 & Mês 10 & Mês 11 & Mês 12 \\
\hline \multicolumn{13}{|l|}{ I. Atividades Operacionais } \\
\hline \multicolumn{13}{|l|}{ Embolsos Operacionais (a) } \\
\hline \multicolumn{13}{|l|}{ Receitas em venda } \\
\hline Boda/ Casamento & $\mathrm{R} \$ \quad 6.661,44$ & $\mathrm{R} \$ 13.322,88$ & $\mathrm{R} \$ 13.322,88$ & $\mathrm{R} \$ 26.645,76$ & $\mathrm{R} \$ 19.984,32$ & $\mathrm{R} \$ 19.984,32$ & $\mathrm{R} \$ 26.645,76$ & $\mathrm{R} \$ 13.322,88$ & $\mathrm{R} \$ 13.322,88$ & $\mathrm{R} \$ 13.322,88$ & $\mathrm{R} \$ 6.661,44$ & $\mathrm{R} \$ 6.661,44$ \\
\hline Festa de Debutante & $\mathrm{R} \$ \quad 12.652,88$ & $\mathrm{R} \$ \quad 6.326,44$ & $\mathrm{R} \$ \quad 6.326,44$ & $\mathrm{R} \$ \quad 6.326,44$ & $\mathrm{R} \$ 12.652,88$ & $\mathrm{R} \$ 12.652,88$ & $\mathrm{R} \$ 6.326,44$ & $\mathrm{R} \$ 12.652,88$ & $\mathrm{R} \$ 18.979,32$ & $\mathrm{R} \$ 25.305,76$ & $\mathrm{R} \$ 25.305,76$ & $\mathrm{R} \$ 18.979,32$ \\
\hline Formatura & $\mathrm{R} \$ \quad 17.159,25$ & $\mathrm{R} \$ 22.879,00$ & $\mathrm{R} \$ 28.598,75$ & $\mathrm{R} \$ 22.879,00$ & $\mathrm{R} \$ 22.879,00$ & $\mathrm{R} \$ 28.598,75$ & $\mathrm{R} \$ 22.879,00$ & $\mathrm{R} \$ 34.318,50$ & $\mathrm{R} \$ 28.598,75$ & $\mathrm{R} \$ 40.038,25$ & $\mathrm{R} \$ 40.038,25$ & $\mathrm{R} \$ 40.038,25$ \\
\hline Total Receita & $\mathrm{R} \$ 36.473,57$ & $\mathrm{R} \$ 42.528,32$ & $\mathrm{R} \$ 48.248,07$ & $\mathrm{R} \$ \mathbf{5 5 . 8 5 1 , 2 0}$ & $\mathrm{R} \$ \mathbf{5 5 . 5 1 6 , 2 0}$ & $\mathrm{R} \$ 61.235,95$ & $\mathrm{R} \$ \mathbf{5 5 . 8 5 1 , 2 0}$ & $\mathrm{R} \$ 60.294,26$ & $\mathrm{R} \$ 60.900,95$ & $\mathrm{R} \$ 78.666,89$ & $\mathrm{R} \$ \mathbf{7 2 . 0 0 5 , 4 5}$ & $\mathrm{R} \$ 65.679,01$ \\
\hline \multicolumn{13}{|l|}{ Desembolsos Operacionais (b) } \\
\hline \multicolumn{13}{|l|}{ Investimento inicial } \\
\hline Despesas Operacionais & $\mathrm{R} \$ \quad(200,00)$ & $\mathrm{R} \$ \quad(200,00)$ & $\mathrm{R} \$ \quad(200,00)$ & $\mathrm{R} \$ \quad(200,00)$ & $\mathrm{R} \$ \quad(200,00)$ & $\mathrm{R} \$ \quad(200,00)$ & $\mathrm{R} \$ \quad(200,00)$ & $\mathrm{R} \$ \quad(200,00)$ & $\mathrm{R} \$ \quad(200,00)$ & $\mathrm{R} \$ \quad(200,00)$ & $\mathrm{R} \$ \quad(200,00)$ & $\mathrm{R} \$ \quad(200,00)$ \\
\hline Condominio (água, energia) & $\mathrm{R} \$ \quad(70,00)$ & $\mathrm{R} \$ \quad(70,00)$ & $\mathrm{R} \$ \quad(70,00)$ & $\mathrm{R} \$ \quad(70,00)$ & $\mathrm{R} \$ \quad(70,00)$ & $\mathrm{R} \$ \quad(70,00)$ & $\mathrm{R} \$ \quad(70,00)$ & $\mathrm{R} \$ \quad(70,00)$ & $\mathrm{R} \$ \quad(70,00)$ & $\mathrm{R} \$ \quad(70,00)$ & $\mathrm{R} \$ \quad(70,00)$ & $\mathrm{R} \$ \quad(70,00)$ \\
\hline IPTU & R\$ $\quad(166,00)$ & & & & & & & & & & & \\
\hline Telefone & $\mathrm{R} \$ \quad(250,00)$ & $\mathrm{R} \$ \quad(250,00)$ & $\mathrm{R} \$ \quad(250,00)$ & $\mathrm{R} \$ \quad(250,00)$ & $\mathrm{R} \$ \quad(250,00)$ & $\mathrm{R} \$ \quad(250,00)$ & $\mathrm{R} \$ \quad(250,00)$ & $\mathrm{R} \$ \quad(250,00)$ & $\mathrm{R} \$ \quad(250,00)$ & $\mathrm{R} \$ \quad(250,00)$ & $\mathrm{R} \$ \quad(250,00)$ & $\mathrm{R} \$ \quad(250,00)$ \\
\hline Manutenção do site & $\mathrm{R} \$ \quad(175,00)$ & $\mathrm{R} \$ \quad(175,00)$ & $\mathrm{R} \$ \quad(175,00)$ & $\mathrm{R} \$ \quad(175,00)$ & $\mathrm{R} \$ \quad(175,00)$ & $\mathrm{R} \$ \quad(175,00)$ & $\mathrm{R} \$ \quad(175,00)$ & $\mathrm{R} \$ \quad(175,00)$ & $\mathrm{R} \$ \quad(175,00)$ & $\mathrm{R} \$ \quad(175,00)$ & $\mathrm{R} \$ \quad(175,00)$ & $\mathrm{R} \$ \quad(175,00)$ \\
\hline Pessoal e encargos & $\mathrm{R} \$ \quad(2.376,00)$ & $\mathrm{R} \$(2.376,00)$ & $\mathrm{R} \$(2.376,00)$ & $\mathrm{R} \$(2.376,00)$ & $\mathrm{R} \$(2.376,00)$ & $\mathrm{R} \$(2.376,00)$ & $\mathrm{R} \$(2.376,00)$ & $\mathrm{R} \$(2.376,00)$ & $\mathrm{R} \$(2.376,00)$ & $\mathrm{R} \$(2.376,00)$ & $\mathrm{R} \$(2.376,00)$ & $\mathrm{R} \$(2.376,00)$ \\
\hline Férias e $13^{\circ}$ & & & & & & $\mathrm{R} \$(1.188,00)$ & & & & & & $\mathrm{R} \$(1.188,00)$ \\
\hline Despesas de combustível & $\mathrm{R} \$ \quad(300,00)$ & $\mathrm{R} \$ \quad(300,00)$ & $\mathrm{R} \$ \quad(300,00)$ & $\mathrm{R} \$ \quad(300,00)$ & $\mathrm{R} \$ \quad(300,00)$ & $\mathrm{R} \$ \quad(300,00)$ & $\mathrm{R} \$ \quad(300,00)$ & $\mathrm{R} \$ \quad(300,00)$ & $\mathrm{R} \$ \quad(300,00)$ & $\mathrm{R} \$ \quad(300,00)$ & $\mathrm{R} \$ \quad(300,00)$ & $\mathrm{R} \$ \quad(300,00)$ \\
\hline Serviços contábeis & $\mathrm{R} \$ \quad(350,00)$ & $\mathrm{R} \$ \quad(350,00)$ & $\mathrm{R} \$ \quad(350,00)$ & $\mathrm{R} \$ \quad(350,00)$ & $\mathrm{R} \$ \quad(350,00)$ & $\mathrm{R} \$ \quad(350,00)$ & $\mathrm{R} \$ \quad(350,00)$ & $\mathrm{R} \$ \quad(350,00)$ & $\mathrm{R} \$ \quad(350,00)$ & $\mathrm{R} \$ \quad(350,00)$ & $\mathrm{R} \$ \quad(350,00)$ & $\mathrm{R} \$ \quad(350,00)$ \\
\hline Material de escritório e diversos & $\mathrm{R} \$ \quad(100,00)$ & $\mathrm{R} \$ \quad(100,00)$ & $\mathrm{R} \$ \quad(100,00)$ & $\mathrm{R} \$ \quad(100,00)$ & $\mathrm{R} \$ \quad(100,00)$ & $\mathrm{R} \$ \quad(100,00)$ & $\mathrm{R} \$ \quad(100,00)$ & $\mathrm{R} \$ \quad(100,00)$ & $\mathrm{R} \$ \quad(100,00)$ & $\mathrm{R} \$ \quad(100,00)$ & $\mathrm{R} \$ \quad(100,00)$ & $\mathrm{R} \$ \quad(100,00)$ \\
\hline $\begin{array}{l}\text { Encargos Tributários (COFINS, } \\
\text { PIS, ISS, IR, Contribuição social) }\end{array}$ & $(284,06)$ & $(337,25)$ & $(1.006,98)$ & $(1.677,82)$ & $(1.362,67)$ & $(1.411,26)$ & $(1.677,82)$ & $(1.100,14)$ & $(1.096,11)$ & $(1.237,86)$ & $(878,14)$ & $(833,58)$ \\
\hline \multicolumn{13}{|l|}{ Pagamentos de Parceiros } \\
\hline Boda/Casamento & $\mathrm{R} \$ \quad(5.751,25)$ & $\mathrm{R} \$(11.502,50)$ & $\mathrm{R} \$(11.502,50)$ & $\mathrm{R} \$(23.005,00)$ & $\mathrm{R} \$(17.253,75)$ & $\mathrm{R} \$(17.253,75)$ & $\mathrm{R} \$(23.005,00)$ & $\mathrm{R} \$(11.502,50)$ & $\mathrm{R} \$(11.502,50)$ & $\mathrm{R} \$(11.502,50)$ & $\mathrm{R} \$(5.751,25)$ & $\mathrm{R} \$(5.751,25)$ \\
\hline Festa de debutante & $\mathrm{R} \$(11.002,50)$ & $\mathrm{R} \$(5.501,25)$ & $\mathrm{R} \$(5.501,25)$ & $\mathrm{R} \$(5.501,25)$ & $\mathrm{R} \$(11.002,50)$ & $\mathrm{R} \$(11.002,50)$ & $\mathrm{R} \$(5.501,25)$ & $\mathrm{R} \$(11.002,50)$ & $\mathrm{R} \$(16.503,75)$ & $\mathrm{R} \$(22.005,00)$ & $\mathrm{R} \$(22.005,00)$ & $\mathrm{R} \$(16.503,75)$ \\
\hline Formatura & $\mathrm{R} \$(14.459,37)$ & $\mathrm{R} \$(19.279,16)$ & $\mathrm{R} \$(24.098,95)$ & $\mathrm{R} \$(19.279,16)$ & $\mathrm{R} \$(19.279,16)$ & $\mathrm{R} \$(24.098,95)$ & $\mathrm{R} \$(19.279,16)$ & $\mathrm{R} \$(28.918,74)$ & $\mathrm{R} \$(24.098,95)$ & $\mathrm{R} \$(33.738,53)$ & $\mathrm{R} \$(33.738,53)$ & $\mathrm{R} \$(33.738,53)$ \\
\hline Total Pagamento Parceiros & $\mathrm{R} \$(31.213,12)$ & $\mathrm{R} \$(36.282,91)$ & $\mathrm{R} \$(29.600,20)$ & $\mathrm{R} \$(24.780,41)$ & $\mathrm{R} \$(30.281,60)$ & $\mathrm{R} \$(35.101,45)$ & $\mathbf{R} \$(24.780,41)$ & $\mathrm{R} \$(39.921,24)$ & $\mathrm{R} \$(40.602,70)$ & $\mathrm{R} \$(55.743,53)$ & $\mathrm{R} \$(55.743,53)$ & $\mathrm{R} \$(50,242,28)$ \\
\hline Total Saída & $\mathrm{R} \$(36.322,18)$ & $\mathrm{R} \$(40.091,16)$ & $\mathrm{R} \$(34.078,18)$ & $\mathrm{R} \$(29.929,23)$ & $\mathrm{R} \$(35.115,33)$ & $\mathrm{R} \$(41.171,71)$ & $\mathrm{R} \$(29.929,23)$ & $\mathrm{R} \$(44.492,38)$ & $\mathrm{R} \$(45.169,81)$ & $\mathrm{R} \$(60.452,39)$ & $\mathrm{R} \$(60.092,67)$ & $\mathrm{R} \$(55.734,86)$ \\
\hline $\begin{array}{l}\text { Fluxo Operacional Líquido } \\
\text { (c) }=\text { (a) - (b) }\end{array}$ & $\mathrm{R} \$ \quad 151,39$ & $\mathrm{R} \$ 2.437,16$ & $R \$ 14.169,89$ & $\mathrm{R} \$ 25.921,97$ & $\mathbf{R} \$ 20.400,87$ & $\mathrm{R} \$ 20.064,24$ & R\$ 25.921,97 & $\mathrm{R} \$ 15.801,88$ & $\mathbf{R} \$ 15.731,14$ & $\mathbf{R} \$ 18.214,50$ & $\mathbf{R} \$ 11.912,78$ & $\mathrm{R} \$ 9.944,15$ \\
\hline \multicolumn{13}{|l|}{ II. Atividades de Investimentos } \\
\hline \multicolumn{13}{|l|}{ Embolsos de Investimentos (d) } \\
\hline $\begin{array}{l}\text { Rendimento de Aplicação } \\
\text { Financeira (poupança) }\end{array}$ & $\mathrm{R} \$ 10.668,85$ & $\mathrm{R} \$ 10.743,53$ & $\mathrm{R} \$ 10.818,74$ & $\mathrm{R} \$ 10.894,47$ & $\mathrm{R} \$ 10.970,73$ & $\mathrm{R} \$ 11.047,52$ & $\mathrm{R} \$ 11.124,86$ & $\mathrm{R} \$ 11.202,73$ & $\mathrm{R} \$ 11.281,15$ & $\mathrm{R} \$ 11.360,12$ & $\mathrm{R} \$ 11.439,64$ & $\mathrm{R} \$ 11.519,72$ \\
\hline \multicolumn{13}{|l|}{$\begin{array}{l}\text { Desembolsos de Investimentos } \\
\text { (e) }\end{array}$} \\
\hline \multicolumn{13}{|l|}{ Movimentação (poupança) } \\
\hline $\begin{array}{l}\text { Fluxo de Investimento Líquido } \\
\qquad(\mathrm{f})=(\mathrm{d}) \text { - (e) }\end{array}$ & $\mathrm{R} \$ 10.668,85$ & $\mathrm{R} \$ 10.743,53$ & $\mathrm{R} \$ 10.818,74$ & $\mathrm{R} \$ 10.894,47$ & $\mathrm{R} \$ 10.970,73$ & $\mathrm{R} \$ 11.047,52$ & $\mathrm{R} \$ 11.124,86$ & $\mathrm{R} \$ 11.202,73$ & $\mathrm{R} \$ 11.281,15$ & $\mathrm{R} \$ 11.360,12$ & $\mathrm{R} \$ 11.439,64$ & $\mathrm{R} \$ 11.519,72$ \\
\hline $\begin{array}{l}\text { Caixa líquido do período } \\
(\mathrm{g})=(\mathrm{c})+(\mathrm{f})\end{array}$ & $\mathrm{R} \$ \quad 10.820,24$ & $\mathrm{R} \$ 13.180,69$ & $\mathrm{R} \$ 24.988,62$ & $\mathrm{R} \$ 36.816,44$ & $\mathrm{R} \$ 31.371,60$ & $\mathrm{R} \$ 31.111,76$ & $\mathrm{R} \$ 37.046,82$ & $\mathrm{R} \$ 27.004,61$ & $\mathrm{R} \$ 27.012,29$ & $\mathrm{R} \$ 29.574,62$ & $\mathrm{R} \$ 23.352,42$ & $\mathrm{R} \$ 21.463,86$ \\
\hline
\end{tabular}


ANEXOS 
ANEXO 1 - Orçamento DJ 


\section{PRESTAÇÃO DE SERVIÇO}

Somos uma empresa capacitada a sonorizar e iluminar de forma personalizada, com bom gosto e sofisticação todo tipo de evento.

Desde um jantar a cocktails, festas, aniversários, formaturas, casamentos, lançamentos de produtos, desfile de moda e som ambiente para lojas, locais públicos e privados.

"A equipe DJ KLEBER FERRAZ avalia o gosto do público-participante e propõe música e iluminação e efeitos especiais de acordo com as necessidades levantadas, para que haja plena satisfação do resultado final".

Evento: Festa de Casamento/ Baile de formatura/ Festa de debutante Local: Dourados ms

Data: à confirmar

\section{Como Solicitado segue em anexo o seguinte pacote para o evento :}

\section{Composição Visual}

01 telão de 120 " (2,40m $\times 1.80 \mathrm{~m})$ e projetor passando clipes e efeitos e ou fotos ao decorrer do evento (telão este que será montado na estrutura).

\section{Composição de Áudio \& Dj}

- 06 caixas (2 graves, 4 try-way (médio agudo amplificadas) montadas em sistema Fly, ou seja, suspensas na estrutura.

- Material necessário para instalação dos mesmos (cabos: p/ energia, som)

- Amplificadores e periféricos para P.A e uso do DJ (CDJ, Mixer)

- 02 Microfones sem fio.

- Mesa de som de 10 canais

- Vasto repertório musical com os mais variados ritmos. (Mpb, rockpop, valsa, techno, dance, funk, pagode, sertanejo, musicas de entrada entre outros, fazemos o repertório conforme a necessidade do evento)

- Repertório musical para entrada dos noivos, valsa entre outros

\section{Dj}

O DJ é aquela pessoa que sabe a hora ideal de tocar e "mixar" determinada música, proporcionando descontração e uma interação afetiva entre os presentes. O evento é um sonho de felicidade que poderá contagiar os convidados. Sendo assim a escolha de um bom profissional com um vasto repertório musical, e uma boa equipe, fará o diferencial da sua festa. "Esta é a 
proposta de trabalho da equipe DJ KLEBER FERRAZ". Contamos com 02 dj's para que a animação do seu evento seja total !!!.

"A iluminação é uma peça essencial para sua festa, incrementando o evento e destacando os espaços. Garantindo assim a animação e descontração dos seus convidados criando um cenário futurista."

\section{Efeitos especiais:}

\section{Move Light}

Luzes com movimento e controle computadorizado, via mesa de comando digital Possibilidade de projetar diversos desenhos. Equipamento com 30 efeitos pré programados, 10 cores (branco, azul escuro, ambar, verde, pink, amarelo, azul, vermelho, verde claro e rosa),

efeito arco íris, efeito estrobo, 9 gobos fixos (desenho) e 01 móvel.

\section{Estruturas (GRID)}

Estrutura de sustentação em aluminio Q30 no formato de " $X$ " ou no formato quadrado, viabilizando montagem sem tripés e furos em tetos e viabilizando as mais diversas montagens. Estrutura esta que servirá de montagem para iluminação, som, panos tensionados e telão.

\section{Fogos Indoor}

São Fogos frios, por não conterem pólvora. Estes efeitos podem transformar qualquer evento em um espetáculo inesquecivel!

Destacam-se por suas pequenas dimensões o que permite uma instalação com um máximo de discrição. Eles não produzem nenhuma fagulha que possam queimar ou danificar o ambiente ou ferir as pessoas e pouca fumaça sem cheiro.

"serão montados na estrutura ou outro local, e serão acionados na hora da valsa ou na entrada dos noivos no salão do ano, dando assim um efeito inesquecível e que emocionará e contagiará a todos."

\section{Sky Paper - maquina de papel picado}

Equipamento de alto impacto visual, capaz de lançar papeis metalizados (formato quadriculado $4 \times 4 \mathrm{~cm}$ ) por todo o ambiente, resultando num efeito visual flutuante $e$ brilhante espetacular,dando a sensação de chuva artificial.

Utilizamos máquina a Gás Ideal para atividades que precisem de um efeito arrojado. Trabalhamos com papéis metalizados.

"Acionada na hora da valsa dos noivos e ao decorrer do evento, garantindo assim um momento impar e que marcará nas fotos e filmagens".

\section{lluminação de pista}




\title{
Acompanha:
}

1. 01 Prisma

2. 01 Globo colorido de 02 rotações

3. 02 Super Strobo 1500 wattz

4. 03 Globo espelhado

5. 01 Máquina de Fumaça ( Cortina de fumaça com aroma Tuti-frutti )

6. 02 Aparelho Ciclon (fachos de luz multicoloridos)

7. 02 movingh head ( aparelho computadorizado projetor de figuras)

Obs. Todos os aparelhos são rítmicos e funcionando sincronizado ao som da pista.

Pacote 01 para o evento:

- 01 Telão + projetor

- Grid

- Áudio

- Dj's

- Move Light

- 04 Fogos Indoor

- 10 Pontos de iluminação para o decoração

- Sky Paper (maquina de papel)

- Iluminação de pista

total em $R \$: 2500.00$

- Grid

Pacote 02 para o evento:

- Áudio

- Dj's

- Move Light

- 02 Fogos Indoor

- Sky Paper (maquina de papel)

- Iluminação de pista

total em R\$: 2100.00

Este orçamento tem validade de 07 dias.

Se necessário, temos outros serviços a oferecer, Aguardo seu contato !! Atenciosamente,

\author{
Kleber Ferraz Soares
}


Anexo 2 - Orçamento Decoração 
Dourados MS, 20 de março de 2007.

ATT:

Ref: Orçamento para decoração de casamento

Tema: Hawaí

Evento: Casamento

Cerimônia: Clube Indaiá

Quantidade de convidados: 300 Pessoas

Prezado (a) Senhor (a);

Em atenção a Vossa Solicitação, é com grande satisfação, que vimos oferecer nosso orçamento para realização do evento acima discriminado:

\section{SERVIÇO DE DECORAÇÃO PARA IGREJA.}

- Ambientação do corredor de entrada da noiva com 10(dez) arranjos, confeccionados em colunas de ferro, madeira ou madeira revestida com tecido adamascado. (a definir)

- 02 (dois) arranjos para o altar.

- Tapete em veludo vermelho ou verde

- Faixa lateral ao tapete.

- Genuflexório.

- Buquê para a noiva (modelo a definir).

- Buquê para a dama (caso tenha). 


\section{DECORAÇÃo do SALÃo.}

- Forração total do salão.

- Ambientação do hall de entrada com 02 (dois) arranjos de grande porte, aparadores, arranjos e tapetes.

- Ambientação de espaço para mesa de bolo e bombons (junto à entrada principal), com mesas em ferro e vidro, arranjos, peças para bolo e bombons em alumínio com vidro ou de madeira, tapetes e plantas sob a mesa.

- 02 (dois) Arranjos para aparadores de jantar.

- Arranjos para mesas de frios (caso tenha).

- Arranjos para mesas de convidados em estilo a definir. (sugerimos os arranjos em dois estilos, alto e baixo).

\section{FLORES}

Para a execução do serviço proposto estaremos utilizando: rosas, flor do campo, gérberas, gladíolo, fórmio e demais complementos.

\section{VALOR E FORMA DE PAGAMENTO}

O valor orçado para a realização do proposto é de $R \$ 5.000,00$ (cinco mil reais) com pagamento a combinar.

OBS: Não incluímos em nosso orçamento iluminação decorativa.

Em nosso orçamento está incluso todas as despesas de transporte e demais necessidades para a realização do seu evento.

Atenciosamente, 


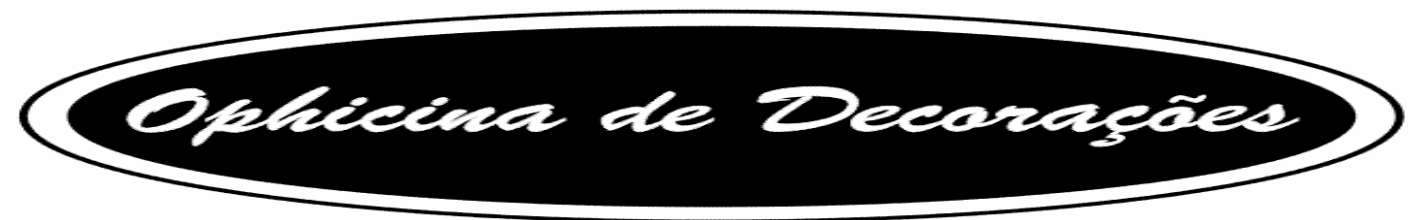

Dourados MS, 20 de março de 2007.

A Sra.

Contato:

E-mail:

Ref. Orçamento e proposta para decoração de 15 anos

Local: Clube Indaiá.

Data do evento: Março de 2008

Quantidade de pessoas: 300

Em atenção a Vossa Solicitação, é com grande satisfação, que vimos oferecer nosso orçamento para realização do evento acima discriminado:

\section{DESCRICÃO DE SERVICO DE DECORACÃO:}

- Ambientação do anti-hall de entrada com 01 (uma) tenda, devidamente forrada, com tablado, aparadores arranjos e plantas naturais.

- Forração total do salão

- Ambientação do hall de entrada com 02 (dois) arranjos de grande porte, aparadores, arranjos e tapetes.

- Ambientação de espaço para mesa de bolo e bombons (mesas de ferro com vidro ou rústica de madeira), acabamento sob a mesa com plantas naturais; peças para bombons em alumínio e vidro ou caixas de madeira.

- Arranjos para mesas de convidados em estilo a definir. (sugerimos os arranjos em dois estilos, alto e baixo).

- Arranjos para aparadores de Jantar, confeccionados com folhagens, flores e frutas.

- Arranjos para mesas de frios.

- Ambientação de espaço para saída da debutante.

\section{FLORES}

Para a execução do serviço proposto estaremos utilizando: rosas, flor do campo, gérberas, gladíolo, fórmio e demais complementos

\section{VALOR E FORMA DE PAGAMENTO DO SERVICO DE DECORACÃO}

O valor do serviço orçado é de $\mathrm{R} \$ 4.000,00$ (quatro mil reais). 
O pagamento poderá ser parcelado, sendo que o montante total deverá estar quitado até 10 (dez) dias antes do evento.

OBS: No presente não incluímos iluminação decorativa, a qual deverá ser solicitada ao DJ, ou então podemos terceirizar com empresa especializada em som e iluminação.

No presente orçamento está incluso todas as despesas de transportes, alimentação, hospedagem (se preciso) e demais materiais necessários para a realização do evento.

Após definição e fechamento, podemos apresentar os testes para arranjos de mesa. Para conhecer nosso material, convidamo-Ihes a conhecer nossa ophicina conforme endereço abaixo.

Eventos recentes realizados na região:

- Casamento de Grizielli Pitta e Nasser.

- 15 anos da Nathalie Acevedo (Clube social Amambay).

- Aniversário da Sra Wacila Derzi (Maçonaria).

- 15 anos da Giovana Hernandéz (hotel Barcelona).

- Ambientação da festa Tropicalíssima (UTC).

Próximos eventos:

- Casamento de Khátia Georges.

- Casamento de Milena Maganha.

Ophicina de Decorações coloca-se a disposição para dirimir alguma duvida e para eventuais mudanças.

Atenciosamente,

Dourados MS, 20 de março de 2007. 
A Sra.

Contato:

E-mail:

Ref. Orçamento e proposta para decoração baile de formatura

Local: Clube Indaiá.

Data do evento: Março de 2008

Quantidade de pessoas: 700

Em atenção a Vossa Solicitação, é com grande satisfação, que vimos oferecer nosso orçamento para realização do evento acima discriminado:

\section{DESCRICÃO DE SERVICO DE DECORACÃO:}

- Ambientação do anti-hall de entrada com 01 (uma) tenda, devidamente forrada, com tablado, aparadores arranjos e plantas naturais.

- Forração total do salão

- Ambientação do hall de entrada com 02 (dois) arranjos de grande porte, aparadores, arranjos e tapetes

- Ambientação de espaço para mesa de buffet (mesas de ferro com vidro ou rústica de madeira), acabamento sob a mesa com plantas naturais;

- Arranjos para mesas de convidados em estilo a definir. (sugerimos os arranjos em dois estilos, alto e baixo).

- Arranjos para mesas de frios.

\section{FLORES}

Para a execução do serviço proposto estaremos utilizando: rosas, flor do campo, gérberas, gladíolo, fórmio e demais complementos.

\section{VALOR E FORMA DE PAGAMENTO DO SERVICO DE DECORACÃO}

O valor do serviço orçado é de $R \$ 4.000,00$ (quatro mil reais).

O pagamento poderá ser parcelado, sendo que o montante total deverá estar quitado até 10 (dez) dias antes do evento.

OBS: No presente não incluímos iluminação decorativa, a qual deverá ser solicitada ao DJ, ou então podemos terceirizar com empresa especializada em som e iluminação.

No presente orçamento está incluso todas as despesas de transportes, alimentação, hospedagem (se preciso) e demais materiais necessários para a realização do evento. 
Após definição e fechamento, podemos apresentar os testes para arranjos de mesa. Para conhecer nosso material, convidamo-lhes a conhecer nossa ophicina conforme endereço abaixo.

Eventos recentes realizados na região:

- Casamento de Grizielli Pitta e Nasser.

- 15 anos da Nathalie Acevedo (Clube social Amambay).

- Aniversário da Sra Wacila Derzi (Maçonaria).

- 15 anos da Giovana Hernandéz (hotel Barcelona).

- Ambientação da festa Tropicalíssima (UTC).

Próximos eventos:

- Casamento de Khátia Georges.

- Casamento de Milena Maganha.

Ophicina de Decorações coloca-se a disposição para dirimir alguma duvida e para eventuais mudanças.

Atenciosamente,

Ophicina de Decorações

Contatos: Endereço Rua Monte Castelo, 1636, Jd. Rigotti, Dourados MS. 
Anexo 3 - Orçamento Clube Indaiá 


\section{Clube Indaiá}

\section{Cotação locação salões}

Salão menor (390 pessoas sentadas/ total de pessoas 600)

- banheiro feminino e masculino

- ar condicionado

- espaço para palco e buffet

- amplo estacionamento

-disponibilidade de 165 mesas e 660 cadeiras

Valores

TERÇA A QUINTA (SOM MECÂNICO)

Locação: 560,00

Taxa eletricista: 105,00

Taxa banheiro masculino e feminino: 140,00

Total: 805,00

TERÇA A QUINTA (MÚSICA AO VIVO)

Locação: 700,00

Taxa eletricista: 105,00

Taxa banheiro masculino e feminino: 140,00

Total: 945,00

SEXTA A SÁBADO (SOM MECÂNICO)

Locação: 784,00

Taxa eletricista: 105,00

Taxa banheiro masculino e feminino: 140,00

Total: $1.029,00$

SEXTA A SÁBADO (MÚSICA AO VIVO)

Locação: 980,00

Taxa eletricista: 105,00

Taxa banheiro masculino e feminino: 140,00

Total: $1.225,00$

SALÂO MAIOR (1.500 pessoas sentadas/ total de pessoas $2.500,00$ )

- sem ar condicionado 
- espaço para palco e buffet

- amplo estacionamento

-disponibilidade de 165 mesas e 660 cadeiras

- banheiro feminino e masculino

PREÇOS VÁLIDOS PARA TODOS OS TIPOS DE SEMANA

CASAMENTO E ANIVERSARIO

Locação:2.240,00

Taxa eletricista: 105,00

Taxa banheiro masculino e feminino: 140,00

Total: $2.485,00$

1 DIA DE LOCAÇÃO

Locação:3.500,00

Taxa eletricista: 105,00

Taxa banheiro masculino e feminino: 140,00

Total: $3.745,00$

2 DIAS DE LOCAÇÃO

Locação:5.600,00

Taxa eletricista: 105,00

Taxa banheiro masculino e feminino: 140,00

Total: 5.845,00 